\title{
THE ELEMENTS \\ OF
}

ENGLISH CONSTITUTIONAL

HISTORY is :

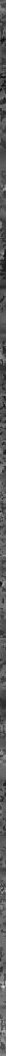


The

Onivensity of Cullfomia
Sibrany
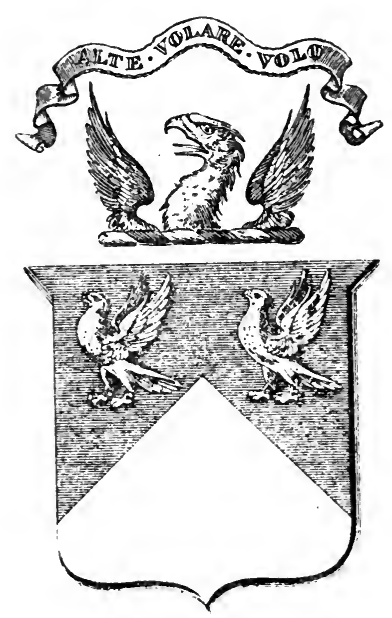

He. Norse Stephens

Unumersity of Sontifumier 


\section{PROPERTY OF}

H.MORSE STEPHENS

DO NOT REMOVE

FROM SEMIIAR

Uhing

11912

$1+101 \cdots$ 


\section{Digitized by the Internet Archive in 2007 with funding from Microsoft Corporation}



CONSTITUTIONAL HISTORY 



\section{THE ELEMENTS OF}

\section{ENGLISH CONSTITUTIONAL HISTORY}

FROM THE EARLIEST TIMES TO THE PRESENT DAY

BY

F. C. MONTAGUE, M.A.

PROFESSOR OF HISTORY, UNIVERSITY COLLEGE, LONDON, LATE FELLOW OF ORIEL COLLEGE, OXFORD

NEW EDITION

LONGMANS, GREN, AND CO. 39 PATERNOSTER ROW, LONDON NEW YORK AND BOMBAY I 897 All rights reserved 


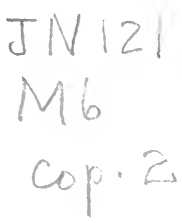

HENET MORSE STEPHZNS

Printed by Ballantyne, Hanson \& Co, At the Ballantyne Press 


\section{P R E F A C E}

THIS little book is designed to give such an account of the growth of English institutions as may be intelligible to those who are only beginning to read history. So far as the writer knows, there is no other book which aims precisely at this object. Our standard constitutional histories are too difficult for beginners, and our school histories are not strictly constitutional, but general in character. In writing a book of this kind, it is impossible to be original. Indeed the author has in one or two instances suppressed doubts or preferences of his own in favour of the views accepted by the greater number of good authorities. He desires to acknowledge peculiarly heavy obligations to the great works of the Bishop of Oxford and Professor Gardiner, and to Sir William Anson's most lucid and accurate treatise on the Law and Custom of the Constitution. $\mathrm{He}$ can but offer a general acknowledgment of his indebtedness to many eminent writers, living or deceased, such as the late Professor Freeman, Mr. Bagehot, and Mr. Morley.

In so slight a sketch of so vast a subject, much that is highly important must be omitted altogether, and much must be stated in terms so general as to come short of 
absolute accuracy. Deficiencies of this kind can be made good only by the knowledge and ability of the teachers, if any, who use a primer of this kind.

In conclusion, the writer has to express his grateful sense of the kindness of Professor Tout of the Owens College, Manchester, who has read the proofs and enriched them with many valuable suggestions. The writer, however, is alone responsible for any errors which may have been embodied in his book.

Oriel College, Oxford,

December 1893 . 


\section{TABLE OF CONTENTS}

\section{CHAPTER I.}

THE BEGINNINGS OF THE CONSTITUTIONAL HISTORY OF ENGLAND, 450-802.

Introduction-Early German Institutions-Classes of Society among the Germans-Political Constitution of the German TribesEffects of the Conquest of Britain-I. Distribution of the Land -II. Relations of Classes-III. Introduction of MonarchyThe Conversion of the English-I. Connection with the Civilised World-II. Promotion of National Unity-III. Influence of the Clergy-Consolidation of the Kingdoms of the Angles and Saxons-I. Originally there were many small Kingdoms-II. The Bretwaldas-III. Supremacy of Wessex . . . . 1-5

\section{CHAPTER II.}

CONSTITUTION OF THE ANGLO-SAXON KINGDOM.

Introduction-Local Institutions--The Township-I. As an Agricultural Community-II. As a Unit of Administration-1II. As an Ecclesiastical Division - Towns - The Hundred, Ward, or Wapentake-The Shire-National Government-The King: how appointed-Powers of the King-Limitations to the Power of an Anglo-Saxon King-The Witenagemote-Origin of the Witenagemote-Composition of the Witenagemote-Powers of the Witenagemote-Conclusion 


\section{CHAPTER III.}

FROM THE BEGINNING OF THE SUPREMACY OF WESSEX TO THE NORMAN CONQUEST, 802-1066.

Introduction-What is meant by Feudalism-When and where PAGE Feudalism grew up-I. The giving of Benefices-II. Commendation-Tendency to Feudalism in the Anglo-Saxon Kingdom - The King - The Nobles - Nobility of Birth - Nobility of Service-Nobility of Wealth-The Anglo-Saxon Nobility not completely Feudal-The Freemen-Political Rights-Military Service-Personal Independence-The Church-General Conclusions

\section{CHAPTER IV.}

THE NORMAN KINGS, 1066-1154.

Introduction-How the Norman Conquest helped Feudalism-How the Conquest hindered Feudalism-The Central GovernmentNecessity of a Strong Central Government-How the Norman Kings succeeded in establishing a Strong Central GovernmentThe King-The Great Council-The Royal AdministrationThe Great Offices of State-The Justiciar-The ChancellorThe Treasurer-The Work of the Royal Administration-I. Norman Finance-Domesday Book-(I) The Lands of the Crown -(2) Feudal Revenue-(3) The Danegelt-(4) The Ferm of the Shire-(5) The proceeds of the Pleas of the Crown-II. Norman Administration of Justice - The Curia Regis-The Circuits of the Royal Commissioners-III. Norman Military System-Local Institutions-The Township-The Hundred-The Shire-The Duties of the Sheriff-I. Finance-II. Justice-III. War-The Towns-Relations between the State and the Church-The Classes of Society . . . . . . . 22-39 


\section{CHAPTER V.}

\section{HENRY II. AND HIS SONS, 1154-1216.}

Introduction-Accession of Henry II.-I. Policy of Henry II. with reference to the Nobles-Introduction of Scutage-II. Policy of Henry II. with reference to the Church-Contest for Jurisdiction over Criminous Clerks-The Constitutions of Clarendon, 1164III. The Policy of Henry II. with reference to the CommonsIV. Policy of Henry II. with reference to Finance-V. Policy of Henry II. with reference to the Administration of Justice-(I) The Development of the Curia Regis-(2) The Improvement of the System of Circuits-(3) The Development of the Jury System VI. Policy of Henry II. with reference to the Military SystemResult of the Reign of Henry II.-Reign of Richard I.-Reign of John-Effects of the Loss of the French Provinces-Effects of the Conflict with the Church-The Conflict of John with the Barons -The Great Charter, I215-I. The Church-II. The Tenantsin-chief - III. The Rights of Cities and Towns-IV. Administration of Justice-V. The Forests-VI. MiscellaneousObservations upon the Great Charter-Death of John . . 


\section{CHAPTER VII.}

THE LATER PLANTAGENETS, 1307-1485.

Introduction-Characteristics of the Mediæval English ParliamentEstates of the Realm-The Mediæval Parliament a Parliament of Estates-The Mediæval Parliament a Parliament of Local Communities-Definition of a Mediæval Parliament-Constitution of the Three Estates in England-I. The Estate of the Clergy - II. The Estate of the Lords Temporal - III. The Estate of the Commons-Classes not included in the Estate of the Commons - Distribution of Representatives - Who were Qualified to Elect Members of Parliament-Who were Qualified to be Elected as Members of Parliament-Freedom of Election -The Right of Representation little Valued-A Seat in Parliament little Valued-Duration of Parliaments-Growth of the Power of Parliament-(I) Control of Taxation by Parliament(2) The Share of Parliament in Legislation-(3) The Responsibility of Ministers to Parliament-Position of the Crown in this Period-Position of the Church in this Period-Position of the Nobles in this Period-Position of the Commons in this PeriodThe Peasant Revolt and the Extinction of Villeinage-Growing Inequality of Conditions . . . . . . . 72-9t

\section{CHAPTER VIII.}

\section{THE TUDORS, 1485-1603.}

Introduction-Relations of the Tudors with their ParliamentsControl of Parliament over Taxation in the Tudor Period-Control of Parliament over Legislation in the Tudor PeriodResponsibility of Ministers to Parliament in the Tudor Period -The Executive Government in the Tudor Period-The Privy Council as a Court of Justice-Why the Privy Council was so convenient as a Court of Justice-Local Administration-The County - The Parish - The Towns-Church Government Measures taken by Henry VIII. to Enforce the Royal Supremacy-Further Reformation by Elward VI.-Reaction under 
Mary-Measures taken by Elizabeth to Complete the Reformation-Act of Supremacy, 1559-Act of Uniformity, 1559-Rise of the Puritans-The Court of IHigh Commission-Close of the Tudor Period-The Nobles-The Clergy-The Commons

\section{CHAPTER IX.}

\section{FAMES I., CHARLES I., AND THE COMMONWEALTH, $1603-1660$.}

Introduction-Character and Reign of James I. - Constitutional Progress during the Reign of James I.-I. Taxation-II. Legislation-III. Responsibility of Ministers-The Administration of Justice-The Church-Character and Early Years of Charles I. -The Absolute Government of Charles I., 1629-40-Taxation - Ship-money - Other Financial Expedients-Distraint of Knighthood-Enlargement of the Forests-Sale of Monopolies -Exorbitant Fines-Administration of Justice-Religion-The Scotch Rebellion and the Short Parliament-The Long Parliament-I. Period of Unanimity in Reform-II. Period of Division ending in the Civil War-Political Differences-Religious Differences-III. The Long Parliament at War with the KingThe Army and the Rump-The Rule of Oliver Cromwell-The Little Parliament-The Instrument of Government-The Parliaments of the Protectorate-The Restoration . . . I13-134

\section{CHAPTER X.}

\section{CHARLES II.-FAMES II.-THE REVOLUTION AND WILLIAM III., 1660-1702.}

Introduction-The Convention Parliament-Abolition of Military Tenures-The High Church Reaction-I. The Act of Uniformity, I66I-II. The Corporation Act, 166I-III. The Conventicle Act, 1664-IV. The Five-Mile Act, 1665-The Royalist Reaction-Decline of Royalist Feeling-The Cabal and the Declaration of Indulgence-The Test Act of 1673-Impeachment of Danby-The Popish Plot-The Parliamentary Test, 1678- 
Whig and Tory-The Exclusion Bill-The Habeas Corpus Act, 1679-The Exclusion Bill brought in again-Reaction in the Country-Forfeiture of the Charters-Accession of James II.The King Attacks the Church of England-The Declaration of Indulgence-The Revolution of 1688 - The Declaration of Rights and the Bill of Rights-Importance of the Bill of RightsAppropriation of Supplies-The Mutiny Act-The Toleration Act, 1689-Liberty of the Press-The Triennial Act-Reform of the Procedure in Trials for High Treason-The Act of Settlement, I701-(1) The Sovereign to be a Member of the Church of England-(2) Attempt to Revive the Privy Council-(3) Exclusion of Placemen and Pensioners from the House of Commons-(4) Independence of the Judges-Conclusion-Personal Influence of William III.

- $135^{-156}$

\section{CHAPTER XI.}

ANNE, GEORGE I., AND GEORGE II., 1702-1760.

Introduction-Reign of Anne-The Parliamentary Union of England with Scotland-I. Unsuccessful Attempts towards UnionII. The Act of Union, I707-The High Church ReactionAccession of the House of Hanover-The Whig AscendencyWhig Legislation-The Septennial Act-The Peerage BillDevelopment of the Cabinet-Party Government-The Two Forms of the Cabinet-The Early Form of the Cabinet-Unpopularity of the Cabinet in its Original Form-Growing Frequency of Cabinet Councils-The Later Form of the CabinetThe Prime Minister-I. The Prime Minister as Controlling the Executive-II. The Prime Minister as the Organ of Communication between the Cabinet and the Sovereign-III. The Prime Minister as the Organ of Communication between the Cabinet and the Parliament-Relation of the Prime Minister to the Individual Members of his Cabinet-Deliberations of the Cabinet -The Working of the Cabinet System-Ministerial Responsibility under the Cabinet System-Final Prevalence of the Cabinet System-Reaction against the Cabinet System-Changes in the Great Offices of State .

157-173 


\section{CHAPTER XII.}

GEORGE III., 1760-1820.

introduction-Accession of George III.-Fall of the Whigs-The King's Friends-The Cabinet System Attacked-The House of Commons and the Influence of the Crown-I. The Cabinet System still New-II. Indifference of the Mass of the PeopleIII. Parliamentary Corruption-IV. State of Parliamentary Representation-Case of John Wilkes-Publication of Parliamentary Debates-Fox's Libel Act, I792-The American WarRenewed Conflicts of the King with his Ministers-The King in Conflict with the House of Commons-The King's Influence in the Latter Part of his Reign-Growing Demands for Parliamentary Reform-Progress of Religious Liberty-The Parliamentary Union of Great Britain and Ireland-Development of Democratic Ideas-I. The Influence of the Great French Writers of the Eighteenth Century-II. The Foundation of the United States -III. The Outbreak of the French Revolution-IV. The Industrial Revolution . . . . . . . . 174-193

\section{CHAPTER XIII.}

GEORGE IV., WILLIAMIV., AND VICTORIA, 1820-1888.

Introduction-I. Progress of Religious Equality-Removal of the Sacramental Test, 1828 -Act for the Removal of Catholic Disabilities, 1829-Admission of Quakers, Moravians, and Separatists to Parliament, \&c. - Admission of Jews to Parliament, \&c. -Admission of Nonconformists to the Universities, 1871 Abolition of Compulsory Church Rates, I868-Disestablishment and Disendowment of the Church of Ireland, 1869-Marriages and Burials of Catholics and Nonconformists-Admission of Evidence in Courts of Justice-II. Parliamentary ReformDefects and Irregularities in-(I) The Distribution of Seats-

2) The Qualifications for the Franchise-The County Franchise - The Borough Franchise-Results of Anomalies in Representation-Causes which led to the Reform of Parliament-The 
Reform Act of 1832-Its Provisions-Its Results-(1) Diminution in the Influence of the Crown and the Landed Interest(2) Differences of Opinion between the House of Commons and the House of Lords-(3) Moderate Temper of the Reformed Parliament-Causes which led to the Reform Act of 1867-The Representation of the People Act of 1867-The Representation of the People Act, I884-The Redistribution of Seats Act, I885 -Abatement of Bribery at Elections-Undue Influence at Elections-The Ballot Act, 1871-Corruption of Members of Parliament-The House of Commons and Public Opinion-The Organization of Parties-Organization for Particular Political Objects-III. Further Development of Cabinet Government and Changes in the Executive Departments-The Cabinet and Legislation-Internal Cohesion of the Cabinet-The Executive Departments-The Secretaries of State-The First Lord of the Admiralty-The President of the Board of Trade-The President of the Local Government Board-The Vice-President of Council-Other Departments of the Executive-Effect of the Increase in the Number of the Departments on the CabinetIV. Reform of Local Administration-Its Condition at the beginning of this Period-The Parish-The Corporate TownsThe Counties-The Poor Law Amendment Act, 1834-The Municipal Corporations Act, I835-The Public Health Acts, 1848-75-The Local Government Act, 1888-Conclusion . 194-228 


\title{
CONSTITUTIONAL HISTORY
}

\author{
CHAPTER I. \\ THE BEGINNINGS OF THE CONSTITUTIONAL \\ HISTORY OF ENGLAND, A.D. 450-802.
}

Introduction.-English constitutional history begins with the settlement in Britain of the Jutes, Angles, and Saxons. These tribes crossed over the sea from Germany at various times between the year 450 and the year 600 . They found the island in the possession of the Britons. The Britons had been subjects of Rome for nearly four hundred years, and some of them, at least, had accepted the Roman form of civilisation. Soon after the year 400 the Roman Emperors gave up their British possessions, which they could no longer defend. The Britons were thus left free, but they were unable to form a strong state of their own, or to drive back the German invaders.

The struggle of the Jutes, Angles, and Saxons with the Britons went on with hardly any pause for one hundred and fifty years. At the end of that time the invaders had made themselves masters of the larger and more fertile part of the island of Britain. Many of the Britons had been slaughtered in this long and cruel war, many had been driven into the western districts, and those who remained in their old homes were mostly reduced to slavery. Their political institutions disappeared from the parts of Britain occupied by the invaders. The political institutions of the invaders were like those of the other German tribes; so that any one who wishes to under- 
starnd the begirnings of the English constitution must turn to the earliest accounts of German laws and customs which have come down to us. ${ }^{1}$

Early German Institutions. - Two great Roman writers have told us much about the laws and customs of the Germans at a time when they were too barbarous to have any books of their own. The first of these writers was Julius Cæsar, the famous general and statesman, who gave an account of the Germans in his Commentaries, or memoirs. The second was Cornelius Tacitus, who wrote a book called the Germania, describing the country and the people. These writers tell us that the Germans were a rough and fierce people, living chiefly on milk and flesh. They were lazy and unskilful in cultivating the land. They had far more land than they could use, and from time to time the chiefs allotted new fields to the people; but war was their favourite occupation.

Classes of Society among the Germans.-A German tribe contained both freemen and slaves. The slaves were of two kinds. Some had houses and families of their own, and cultivated their master's land, giving him a part of the produce. These seem to have been what we should call serfs rather than slaves. Another kind, but less important, consisted of persons who were slaves in the strict sense of the term. Of the freemen some were noble, and the rest not noble. The nobles had larger portions of land allotted to them. They were also preferred in the election of chiefs. But every freeman had a share of political power, and might be elected to high office if he had shown himself worthy. The chiefs maintained bands of followers, who were bound to them by a special tie of fidelity, and fought for them in time of war.

1 There has been great difference of opinion as to (I) the extent to which the Britons were extirpated in the districts occupied by the German invaders; (2) the proportion of the free to the servile population after the conquest had been completed; (3) the nature of the Anglo-Saxon land system. These questions hardly admit of precise determination, and cannot be discussed here. The statements in the text represent the opinions which have hitherto found the most general acceptance with historians. 
Political Constitution of the German Tribes.-Some German tribes had kings; others, like the Angles and Saxons before they left Germany, had none. The tribes which had kings elected them out of some noble family. The tribes which had no king lived under elected chiefs, who governed each his own district or hundred. In time of war such a tribe elected one leader; but the power of the king and of the chiefs was limited by the power of the assembly of the tribe. Every freeman had a right to come to this assembly. All iniportant public affairs were discussed in it ; it elected the kings and chiefs ; it tried persons accused of capital crimes; it decided on peace and war.

Effects of the Conquest of Britain.-The conquest of Britain by the Angles and Saxons had important effects upon the institutions which we have been describing.

I. Distribution of the Land.-Different accounts have been given of the distribution of the land taken from the Britons. At a later time we read of two sorts of landed property - folkland and bookland. Many historians have held that folkland was public property, as opposed to the land at once distributed among individuals or small groups of persons; that for grants made out of this public land a writing or charter came to be used, and that the land thus granted was the bookland. At last the name of bookland came to be given to all land held as private property. Other historians have thought that folkland was not public property, but was land held by custom (folkright), as opposed to land held in virtue of a written grant. Be this as it may, it is certain that in every kingdom a large extent of land was set apart for the king, so as to provide him with proper maintenance and the means of rewarding service.

II. Relations of Classes. - The conquest of Britain probably affected the relations between the various classes of German society. The Angles and Saxons were now masters of a country larger and more fruitful than the country which they had left. They would probably be much richer than before. Probably also there would be much more inequality of possessions. Many of the con- 
quered Britons had become the slaves or serfs of their conquerors. In this way the proportion of persons not free would be greatly increased. But the same classes which had existed among the Germans in their own country continued to exist among the Germans settled in Britain.

III. Introduction of Monarchy. - The Angles and Saxons in their old homes were not governed by kings. But the Angles and Saxons of Britain seem to have had kings almost from the time of their landing. This was the natural result of the state of constant warfare on which they then entered. War cannot be carried on successfully without unity of will and unity of plan. A rude people cannot reach this unity in any other way than by making a king to rule over them. Even those German tribes which had no king in time of peace elected one man to lead them in time of war. And the wars of the Angles and Saxons in Britain were so long and fierce that such leaders were needed for many years. Thus leadership early passed into kingship.

The Conversion of the English.-The conversion of the English to Christianity began in the year 597 with the landing of St. Augustine in Kent. Nearly one hundred years passed before it was finished. Its effects upon constitutional history were most important.

I. Connection with the Civilised World.-The Angles and Saxons had been among the rudest of the German tribes. In their new home they had learnt little from the civilised people which they had subdued. If they had remained heathen, they must have continued barbarous for a very long time. By becoming Christians they were brought within the civilised world. They became familiar with the other Christian peoples. For the first time their laws and institutions began to be affected by laws and institutions existing on the continent of Europe.

II. Promotion of National Unity.-The conversion of the English promoted their unity in two distinct ways. First, they all became members of the one Christian Church. Politically they were still divided into a number 
of petty kingdoms. These kingdoms were usually quarrelling with each other. But the inhabitants of all these kingdoms were now Christians, at least in name. This helped to make their quarrels less savage. Secondly, the English did not receive their instruction in Christianity from the other peoples of Britain. The Britons who remained free had remained Christian, but had not tried to convert the Angles or Saxons. The Irish missionaries had converted the Picts, and even made some progress in the north of England, but they afterwards retired before the Roman missionaries. The Roman missionaries were then followed by all the English. This fact helped to distinguish the English as a nation from their neighbours.

Soon after the Irish missionaries had been driven out by the Roman missionaries, a famous archbishop of Canterbury, Theodore of Tarsus, organized the Church in England. Theodore came from that city in which St. Paul had been born. He became Archbishop in the year 670. He completed the division of England into dioceses (districts governed by a bishop). He provided that all the bishops should meet once a year to discuss the affairs of the Church. Thus there was one church government for the whole of England long before there was one kingdom of England. It was in managing the affairs of the Church that men belonging to the different English kingdoms first learnt to act together.

III. Influence of the Clergy.-The heathen priests do not seem to have had much political power among the English ; but the Christian clergy at once became powerful in politics. Their sacred office protected them from violence. Kings and rich men bestowed so much land upon them that they became very wealthy. They were learned men. They could read Latin, and so had the key to all the knowledge then available. They had ideas of law and administration which were new to the English. From the conversion of England down to the Reformation a great part of the work of government was done by clergymen. 
Consolidation of the Kingdoms of the Angles and Saxons.-Another change which had great influence upon the institutions of the English tribes was the union of their petty kingdoms into one.

I. Originally there were many Small Kingdoms.-This was due to the fact that Britain had been conquered, not by one great army, but by many small bodies of men. For a long time these kingdoms had enough to do in fighting with the Britons. Then they began to fight among themselves.

II. The Bretwaldas. - In the course of these struggles one kingdom after another took the first place. The king who was the most powerful for the time being was called Bretwalda (perhaps ruler of Britain). Seven of these Bretwaldas are mentioned by historians. Among them are kings of Kent, East Anglia, Northumbria, and Mercia. But we must not suppose that any of these Bretwaldas was really ruler of all Britain, or even of all the English. The other kingdoms continued to exist, usually under their own kings, and without any change in their laws or customs. They followed the king of the strongest kingdom in war, and that was almost their only real dependence. None of the greater kingdoms was able to keep even this supremacy long.

III. Supremacy of Wessex.-At last the kings of Wessex succeeded in bringing all the English peoples under their supremacy. Egbert, who became king of Wessex in 802, received the submission of the Mercians and Northumbrians. But his supremacy was not essentially different from the supremacy enjoyed by the earlier Bretwaldas. The old kingdoms went on under the government of hereditary ealdormen, in some cases descended from the old royal families. It was not until the Danes had wasted great part of Mercia and Northumbria, and these lands had been won back for the English by the successors of Alfred, that all England can be said to have been really united under one king. 


\section{CHAPTER II.}

\section{CONSTITUTION OF THE ANGLO-SAXON KINGDOM.}

Introduction.-If we had to describe to a stranger the English Constitution at the present day, we should begin with telling him about the national government, the Queen, the Houses of Parliament, the ministers, and the judges. We should then go on to describe the local administration of the country, the authorities of counties, and parishes, and municipal boroughs.

But in describing the Constitution of England in the days of Alfred or Athelstan, it is better to do the reverse of this. It is better to begin with describing the local institutions, and to end with describing the national government.

One reason why it is better to begin with the local institutions is that they are in many cases older than the kingdom of England. It is easy to understand this if we remember that Britain was conquered by a number of independent chiefs, and piece by piece.

The other reason is that, in the time of which we are now writing, the local institutions were more important than any other institutions. The German tribes which settled in England were fond of self-government, and every freeman thought it natural that he should take part in public affairs. But he cared more about the affairs of his own district than about the affairs of the whole English people. He settled most matters which concerned his daily life in his local assembly, and with the help of his neighbours. National business he usually left to the king and his counsellors. It was almost 
impossible for any but the rich to take part in the government of a great kingdom before representative parliaments had been established.

Local Institutions-The Township.-The smallest selfgoverning division of the Anglo-Saxon kingdom was the township. The township exists even to this day, sometimes under its old name, but oftener as the parish. The townships had been formed gradually and in different ways during the conquest of Britain. A number of kinsfolk sometimes occupied a tract of land on their own account, or had it allotted to them by the chief whom they followed. Sometimes a noble, who owned such a tract, formed his serfs or dependents into a township. However it arose, the township was important in three ways-

I. As an Agricultural Community.-On this subject learned men have written a great deal, and a great deal is still doubtful. But this much is plain, that in each township part of the land was common pasture, and that another part was cultivated in common under bye-laws made by the township. The commons which are found in so many parts of England are relics of the common pasture.

II. As a Unit of Administration-The inhabitants of the township had their general meeting, their gemot, which was held regularly once a month. In these assemblies the townsmen made their bye-laws and elected their officers, the gerefa or reeve, and the bydel or beadle; they also elected persons to represent them in the assembly of the larger divisions, the hundred and the shire. They also settled petty disputes among themselves, and carried out the orders of higher authorities respecting such matters as taxation or the pursuit of criminals.

III. As an Ecclesiastical Division.-The smallest ecclesiastical divisions of England, the parishes, were formed by degrees, and were not completely marked out till many centuries after the conversion of the English. But, in the south of England, when a parish was formed, it usually covered the same ground as a township already existing. There are, however, many exceptions to this 
statement. It does not apply generally to the north of England.

Towns. - The township was not necessarily a town in our sense of the word. Usually it was altogether agricultural. At this time the population of England was small, and the English disliked town life. So they left most of the Roman cities which they found in Britain to fall into ruin. But when a country becomes peaceful, towns necessarily grow. Some of the Roman towns had never been quite forsaken; others were re-occupied, and new towns began to appear on fresh sites. Most of these towns were such as we should now think mere villages. None was what we should think a large town. At present the dwellers in cities and towns are more numerous and powerful than all the rest of the English people; but in the Anglo-Saxon period they were few and had little power. A town had the same organisation as any other township. It had a gerefa, sometimes called the port-gerefa (i.e., gate-reeve, Lat. porta, a gate). It had its common pasture, still retained by a few towns, as the "Port-Meadow" of Oxford.

The Hundred, Ward, or Wapentake.-The hundred was a larger local division including a number of townships. The name still survives, as in the Chiltern Hundreds in Buckinghamshire, or in the Hundred of Isleworth in Middlesex. It is said that, if any man's house and goods are injured in a riot, he can bring an action for damages against the hundred. For other purposes the hundred is now no longer used, and few Englishmen could tell in what hundred they dwell. But in Anglo-Saxon times the hundreds had a large share of self-government. How they were at first formed is not known. Their name first appears in the laws of King Edgar (957-975). But they had probably existed for centuries before his reign. They are very unequal in size. A hundred may possibly have been the district originally occupied by a hundred German warriors. In some parts of England this subdivision of the land was known as the ward or wapentake. 
The assembly of the hundred, the hundred mote, was held once a month. It was attended by the principal landowners or their stewards, and by representatives of each township in the hundred, namely, the priest, the reeve, and the four best men elected for this purpose. The hundred mote tried both civil and criminal cases. All persons entitled to attend were qualified to act as judges. But, as they would have been too many, it was usual to elect twelve men to form a court.

The hundred had also an elective head, the hundred man or hundreds-ealdor.

The Shire.-The shires were formed at different times and in different ways. Some were originally small kingdoms, which afterwards lost their independence. Kent, Sussex, Surrey, Middlesex, and Essex were of this class. Others were subdivisions of large kingdoms already existing. Thus Norfolk and Suffolk were the northern and southern divisions of East Anglia. The present shires of the midlands and north of England differ in most cases from the original divisions of Mercia and Northumbria. The Mercian shires were arranged and named as at present, after Mercia had been won back from the Danes in the tenth century. The only shire of Northern England which had taken almost its present form before the Norman Conquest was Yorkshire. Lancashire was not formed until the twelfth century. Each shire contained a number of hundreds. Like the hundred, it had its general assembly, the shire-mote, which was held twice a year, and was attended by the representatives of every township, and by all the great landowners and public officers. The shire-mote had power to try both civil and criminal causes. But this business seems to have been intrusted to twelve thegns on behalf of the whole body. The head of the shire was the ealdorman (alderman). He was elected, not in the assembly of the shire, but in the assembly of the nation. But his office tended to become hereditary. The ealdorman of the shire was often the descendant of its old royal family in the 
days when it had been an independent kingdom. The ealdorman and the bishop both sat in the shire-mote to declare, the one the law of the land, the other the law of the Church. But the president of the shire-mote was the shire-reeve or sheriff, the officer appointed by the king to enforce the law, and to take charge of the Crown lands in the shire. In time of war the fighting men of the shire were mustered and commanded by the ealdorman.

National Government.-The government of the English nation after it had been united was in the hands of the king and witan, or wise men.

The King: how appointed.-We have seen that among the Germans kingship was elective, but that members of a noble family were preferred in election. In the Anglo-Saxon kingdom this continued to be the case. But kingship was always tending to be hereditary. The king was usually chosen out of one family. The member of the family chosen was the one whose age and other qualities marked him out as fittest to rule. Thus Alfred was chosen in preference to his nephews, the sons of King Ethelred. The German kings had been elected by the general assembly of freemen. In theory this may have been considered proper in England. In practice the Anglo-Saxon king was elected by the witan in presence of such freemen as were able and willing to attend the election.

Before the conversion of the English to Christianity, the kingly families used to claim a divine origin. Thus Cerdic, the founder of the kingdom of Wessex, and the ancestor of Alfred and Queen Victoria, was ninth in descent from Woden, the supreme god of the Germans. After the conversion such legends were no longer believed. But the ceremony of consecration was added to the ceremony of election. The king was now the Lord's Anointed, and his authority received the sanction of religion. Before his consecration he swore to govern justly and according to law.

Powers of the King.-The larger the kingdom, the 
more difficult it was to keep up government by a general assembly of the nation. The larger the kingdom, the more the king was exalted over the heads of his noblest and richest subjects. So it was natural that a king of England should be more powerful than the petty German kings had been. The powers of the Anglo-Saxon king may be shortly described as follows.

The king was the leader of the people in time of war. In time of peace he was supreme judge and lawgiver; but he had to act with the consent of the witan. Direct taxation was almost unknown at this time. But the king and the witan decided when it was necessary to impose a tax. The king's revenue was partly derived from land. Besides the private estate of the kingly house, there was a large demesne of the Crown which went along with the kingly office. The king had also the right of making grants of land with the consent of the witan. If it be true that the folkland was public property, these grants were made out of the folkland. If it was not public property, they must have been made out of the royal demesne. But the bulk of what he received from his land would be, not money rents, but goods in kind, which served for the maintenance of his numerous household. Among the dues of the kingly office were the fines and fees levied in the courts of justice, the produce of mines and saltworks, wrecks and treasure-trove. But the revenue of an Anglo-Saxon king was small in comparison with that of the Norman kings. Like the German kings of early times, he had a retinue of freeborn companions, his gesiths or thegns. They served him in war and peace, and he provided for them out of the folkland.

Limitations to the Power of an Anglo-Saxon King.The Anglo-Saxon king was in reality far less powerful than one would suppose from the above statement. He had only a small revenue; he had no standing army; he had no large body of officials and administrators to assist him. Most of the common work of administration was done by the various local authorities. There was very 
little legislation. The laws of Ethelbert and Ine, and later kings, seem to be little more than new statements of old customs, with a few additions and improvements. Lastly, every freeman was a warrior. If the people found themselves oppressed, they had both the power and the will to resist. So the power of the king depended a good deal upon his character. If he was wise and brave, he was respected and obeyed; if he was foolish and cowardly, he counted for very little.

The Witenagemote.-But the most definite check upon the power of the Anglo-Saxon king was the custom which required him, in all important public business, to take counsel with the witenagemote, the assembly of wise men.

Origin of the Witenagemote.-Among the primitive Germans, matters of great importance had been decided by an assembly of all the freemen; but the discussion in this assembly must have been carried on for the most part by the chief men. When the Angles and Saxons settled in Britain, the larger their territory became, the smaller was the proportion of persons who could attend the national assemblies. The king and the chief men would always be there; but only such of the common people as dwelt close at hand would be likely to come. They would be too few to have much influence. Thus an assembly of the chief men would gradually take the place of an assembly of the nation.

Composition of the Witenagemote.-The witenagemote was always a small body. The king presided, and his queen and sons sometimes accompanied him. His personal friends, his ministers of state, the chief officers of his household, his thegns and gesiths, would also attend. The ealdormen of the different shires and the bishops formed part of the assembly. King Edgar's witenagemote in 966 contained the king's mother, two archbishops, seven bishops, five ealdormen, and fifteen of the king's servants. Thus it was not what we should call a representative body. After the Norman Conquest it became the Great Council of the Norman kings, and this 
in turn grew into the House of Lords. But in the records of the action of the witenagemote, reference is occasionally made to the assent of the whole people. This assent was probably expressed by such freemen as lived near enough to the place of meeting to attend without much trouble.

Powers of the Witenagemote.-The witenagemote had a share in all the important public business transacted by the king. With its counsel and consent he made laws, gave grants of land, administered justice, and decided matters of general policy, such as the question of war or peace. The election and deposition of a king were performed by it in the general assembly of the nation; but it is not easy to say how far it actually controlled the king in quiet times.

Conclusion.--Such was the Anglo-Saxon Constitution. It was simple and not oppressive. Its great defect was the weakness of the national government. This weakness was brought to light by the Danish invasions, which ended in the conquest of England. Its great merit was the vigour of the local institutions. These institutions survived the Norman Conquest, and kept alive the love of liberty until the foundation of the English Parliament. 


\section{CHAPTER III.}

FROM THE BEGINNING OF THE SUPREMACY OF WESSEX TO THE NORMAN CONQUEST, 802-1066.

Introduction. - The constitution described in the last chapter lasted until the Norman conquest of England. But, for a long time before that conquest, the political and social condition of England had been slowly changing. The change which was going on can best be described as the growth of Feudalism.

What is meant by Feudalism.-Feudalism was a system under which the political rights and duties of every man were determined by his relation to the land. In a feudal kingdom every man owed faith and service to the lord of whom he held his land, and the lord owed protection to his man. The king was supreme landlord of the whole kingdom. Those who held their land directly from him formed the highest class. Others held land from these tenants-in-chief, as they were called, and formed inferior classes. Every lord "judged, taxed, and commanded the class next below him." Only the highest class was under the direct government of the king. Each member of this class was a petty prince, with his own territory, his own fortresses, his own army, his own courts of justice, and his own treasury. Those. who held of him might again be princes on a still smaller scale. Lower still came the actual cultivators of the soil. Under the feudal system the power now centred in the national government was thus scattered among a multitude of rulers who were ranged in ranks one above another. The king was weak because the lords were strong, and the lowest class was 
oppressed because there was no impartial power strong enough to restrain overbearing individuals. But the upper classes enjoyed political freedom, and valued it highly. Feudalism impeded good government, but it also impeded absolute government.

When and where Feudalism grew up.-Feudalism did not prevail, either in the Roman Empire or among the Germans in their own country. It grew up in Western Europe after the German tribes had conquered the Roman provinces. It grew chiefly out of two practices known as -I. the giving of benefices ; II. commendation.

I. The giving of Benefices. - The benefices here meant had nothing to do with the Church. They were grants of land made by the German kings to the warriors who had helped them in the conquest of Roman territory. These warriors became at once landlords and governors of large tracts cultivated by the conquered people. The conquered people became their tenants and subjects.

II. Commendation. - The practice of commendation consisted in one man submitting himself to another who, in return, promised to protect him. It grew out of the disorder which followed the downfall of the Roman Empire. 'This disorder lasted for several centuries, and was interrupted only by the occasional rise of some great ruler. Usually the strong did what they liked, and the weak suffered accordingly. So men were willing to give up a freedom which brought them no happiness. Any authority, however oppressive, seemed better than no government at all. He who wished to commend himself to a lord knelt down, placed his hands in the hands of the lord, and took an oath of fealty (faith) to him. The lord undertook in return to protect him from all enemies.

Chiefly in these ways Western Europe was gradually covered with a vast number of small societies, each ranged round a feudal lord and owing him obedience. $\mathrm{He}$ usually owed fealty to some higher lord. Thus these little societies were bound into larger societies, and these in turn were bound into great kingdoms. But the 
wider the bond, the weaker the bond. Kings were kings only in name, and there was still a great deal of lawless confusion. Feudalism was not the result of any enactment or of any policy devised by one man. It grew up by degrees and in many shapes. But, by the end of the ninth century, feudalism was established all over Western Europe.

Tendency to Feudalism in the Anglo-Saxon Kingdom.-Complete feudalism came later in England than elsewhere. One reason of this was that fewer of the old population had been left in Britain than in the other countries conquered by the Germans. The Franks in Gaul and the Goths in Spain were only an aristocracy. But in England the Angles and Saxons were a large part of the inhabitants. So the old German ideas of freedom and equality were stronger in England. Another reason was that the English were cut off from their neighbours by the sea, and were the less likely to imitate their customs. As feudalism came late, it used to be thought that feudalism was first brought into England at the Norman Conquest. But this is a mistake. Before the Norman Conquest feudalism had made great progress. The Normans only completed what had long been in growth.

The changes which took place in England during this period were very gradual. We have scanty records of what happened. But, by taking one after another the results in each degree of society, we can see that these changes made for the establishment of feudalism.

The King.-In this period the king first gained and afterwards lost power.

The Anglo-Saxon king was the captain of his people. The long wars with the Danes, which made a leader always necessary to the English, thus bound them closer to their kings. Alfred and his successors were great warriors and statesmen, who gave lustre to the kingly office. For many years after the death of Alfred the kingdom continued to grow, and Edgar (957-975) was acknowledged as overlord of all Britain. This also helped 
to magnify the king. He became more independent of the witan, in particular as regards grants of land.

But after Edgar came weak and bad kings. The Danes again invaded England, and did terrible mischief. Even the king's greater freedom in making grants of land tended to weaken him. For the kings were in the habit of granting with the land jurisdiction over the persons living on it. Thus they raised up a class of landowners who governed the people on their lands, and were really feudal lords. When Canute conquered England, he divided it into four great earldoms answering to the old kingdoms of Wessex, Mercia, Northumbria, and East Anglia. The earls thus established became, after Canute's death, more powerful than the king himself. The reign of Edward the Confessor is chiefly taken up with the troubles caused by the rivalry of these great earls. Harold, son of Godwin Earl of Wessex, seized the crown on the death of Edward. He was defeated at Hastings, partly because the rest of England did not care for the house of Godwin.

The Nobles.- In the Anglo-Saxon kingdom the nobles, the thegns and earls, became more powerful as time went on. Nobility had three sources-noble descent, service rendered to the king, and wealth.

Nobility of Birth.-From the first there had been among the German tribes families of noble blood. When the little kingdoms formed in Britain were united into the kingdoms of the heptarchy, and these again into one kingdom, the dispossessed royal families went to swell the class of nobles by birth.

Nobility of Service.-We have seen that the AngloSaxon king had his retinue of freeborn followers who served him in his household or in war. These followers were called gesiths or thegns. The greater the dignity of the royal office became, the greater was the dignity of these followers. The king usually rewarded their service with grants of land; so they became rich and powerful.

Nobility of Wealth.-We have just said that the king gave lands to those who had become ennobled in serving 
him; but other men who gained a landed estate might become noble. The ceorl (churl), or free man of the lower class, who acquired five hides of land, became a thegn; the churl who acquired forty hides of land, became an earl. The successful merchant might also become a thegn; but then he would probably try to become a landowner. In these cases the qualification by service rendered to the king tended to become merely formal.

At last the noble class, which had once consisted of men of high descent, came to consist of landowners. Instead of a nobility of birth, there was now a territorial nobility. As the king often granted jurisdiction together with land, this territorial nobility was very like a feudal nobility. Canute's creation of four great earls, with almost kingly power over the four quarters of England, carried the change further.

The Anglo-Saxon Nobility not completely Feudal.Even in the last period of the Anglo-Saxon kingdom, the nobility had not become altogether feudal. It was not yet supposed that every noble was a tenant of the king, or that the king was lord of all the land. The cultivators of the soil were not yet uniformly regarded as holding of superior lords. Many of the nobles had jurisdiction over their people; but the old popular courts, especially the court of the shire, remained free. Nor were the nobles supposed to be the only ruling class.

The Freemen.-The bulk of the free population seems to have sunk to a less honourable condition in the course of this period. When the German tribes first settled in Britain, every freeman had enjoyed political rights. $\mathrm{He}$ was entitled to attend the national assembly and to give his vote on public affairs. Again, he was a warrior, entitled and obliged to serve in the field. Lastly, he had entire personal independence irrespective of his possessing property in land. On all these points a great change had taken place before the Norman Conquest.

Political Rights.-We have seen that in the united Anglo-Saxon kingdom, the popular assembly had become 
a mere form. The witenagemote was the only body which limited the royal authority. Thus the mass of the freemen lost the greater part of their political power. But they preserved their right in the assemblies of the township, hundred, and shire, which were still full of vigour. They still had a share in the local, although not in the national administration.

Military Service.-Every freeman was still legally liable to serve in the host. The fyrd or militia was never abolished by law. But, as civilisation advanced, the soldier's equipment became more costly, and men became less willing to serve. In most cases only the landowners were compelled to serve. A landowner had to provide one fully armed soldier for every five hides of land held by him. The rest of the people became unwarlike, and this change helped the Danes and Normans to conquer England.

Personal Independence.-As time went on, the mass of the freemen became more and more dependent. In the confusion caused by the Danish invasions during the ninth century, the practice of commendation became $\sim$ common in England. Thus many freemen gave themselves lords, in order to get better protection. When the Danes had been vanquished, the laws made by the AngloSaxon kings to restore peace and order were unfavourable to the independence of the poorer class. By a law of Athelstan it was provided that the man who had no land of his own must find a lord to answer for him. Thus the freeman who had no land became the dependent of a landowner.

The Church. - In the later Anglo-Saxon period the Church had become extremely wealthy, and, perhaps for this reason, less energetic. Her influence in the State was powerful; but after Dunstan she did not produce any able statesman to grapple with the difficulties of the time. England always maintained a comparative independence of Rome, and this was the motive which led the Pope to approve the invasion of William the Norman. 
General Conclusions.-Towards the close of this period the English nation had outgrown its primitive institutions, and had not found new institutions adequate to its wants. Government by an assembly of all the free men might have answered in a petty German tribe: it had long been impossible in a great people. But no system of representation had been contrived to take its place. Feudalism was growing, to the disadvantage of the common people, yet without calling forth the warlike energy which was the chief virtue of feudal society. The king lacked power to perform the work of government. The Church was inactive. A new impulse was everywhere required. That impulse was given by the Norman Conquest. 


\section{CHAPTER IV.}

\section{THE NORMAN KINGS, IO66-II54.}

Introduction.-We have seen what is meant by feudalism. We have also seen that feudalism had made considerable progress in England before the Norman Conquest. The Norman Conquest had a double effect upon feudalism in England. It helped feudalism, and it hindered feudalism.

How the Norman Conquest helped Feudalism.-At the time of the battle of Hastings England was half feudal. William the Conqueror came from a country $\checkmark$ which was altogether feudal. So he and his Normans quickly established in England the feudal doctrine of tenure, the doctrine that every man holds his land either from the king or from some other lord. After the Conquest a great part of the land of England was forfeited by its English owners. William granted it to his followers, to hold as feudal tenants in reward of their service, and to maintain a military force in the kingdom. Moreover, the Norman lawyers, coming from a country where feudalism was more complete than in England, were apt to treat land, whether held by Englishmen or by Normans, as held on feudal tenure. So the first result of the Conquest was to hasten the growth of feudalism in England, to make English society more feudal than formerly.

How the Norman Conquest hindered Feudalism.But William had learnt by experience that feudal nobles, if powerful, were always rebellious. As Duke of Normandy, he had fought and defeated his liege lord, the King of France; and he had found much trouble in putting down his own disorderly vassals. So he resolved not to 
make his English vassals too powerful. The precautions which he took were as follows:-

(I.) He did not destroy, but recognised and protected the old local assemblies of the township, the hundred, and the shire. The English continued to meet in these assemblies to manage their local affairs and to settle their disputes. In this way the old English habits of joint action and self-government were kept alive, and the English were saved from becoming a mere crowd of miserable and helpless peasants. They remained a nation, and were able to turn the scale when the Norman king was at war with the Norman nobles.

(2.) William took care not to bestow upon any man a great extent of land in one part of England. When he gave much to a friend or follower, he gave it in many scattered estates. The only exceptions to this rule were on the borders of the kingdom. The Bishop of Durham had a large territory, in order that he might defend the north against the Scots. The Earls of Cheshire and Shropshire had large territories, in order that they might defend the west against the Welsh. As most of the Norman lords had only scattered estates, they could not collect armies quickly or secretly, and therefore would be less likely to rebel against the king.

(3.) William wished all the landowners of England, both great and small, to feel that he was their lord, and that they were bound to obey him in preference to any other man whatsoever. For this reason he made them all swear fealty to himself. This seems natural to us, but it was not usual in other feudal countries. In other feudal countries it was usual for each man to swear fealty to the lord who granted him land. The tenants-in-chief swore fealty to the king from whom they received their land; but their tenants swore fealty to them only, not to the king, and those who received land from their tenants swore fealty to those tenants only. Thus the Duke of Normandy swore fealty to the King of France; but the Norman barons swore fealty only to the duke. When 
the duke made war on the king, his barons did not scruple to follow him against the king. William did not wish that such things should happen in his kingdom. He held a great assembly of all the landowners of England at Salisbury, in the year 1086, and made them all swear fealty to him. This oath was meant to override any oath of fealty which they might have taken to their landlords.

The Central Government.-A second important result of the Norman Conquest was to establish a strong central government. The government of the Anglo-Saxon kings had not been strong. It had not been able to draw out all the resources of the kingdom in men and money. In consequence, England had been conquered by foreigners. But the government of the Norman kings was strong enough to utilise all the force of England, and to secure her from any further conquest.

Necessity of a Strong Central Government. - The Norman kings found it necessary to be strong, if they were to govern at all. For they were in a double danger. First, they had reason to fear the English people whom they had conquered, and whom they ruled very harshly. Secondly, they had reason to fear the Norman nobles, who thought that, as they had helped to conquer England, they had a claim to be masters of England.

How the Norman Kings succeeded in establishing a Strong Central Government.-The Norman kings succeeded in this work for various reasons. One reason lay in their personal character. William the Conqueror, William Rufus, and Henry I. were all men of ability, courage, and stubborn will. William the Conqueror and Henry I., although greedy, were prudent, and knew how to protect those that submitted to them. Another reason lay in the division between Englishmen and Normans. The English saw that the Norman king was their only protector against the oppression of the Norman lords, and they stood by him accordingly. A third reason lay in the arrangements made by William after the Conquest 
to prevent any of the feudal vassals from becoming too powerful.

We shall understand the strength of the new central government by considering separately the King, the Great Council, and the Royal Administration.

The King.-The Norman kings were more absolute than any other kings who have ever ruled in England. Their absolute power was not the result of any definite legal change. William the Conqueror claimed England as the heir of Edward the Confessor. But the old ideas and customs which had limited the power of the AngloSaxon king had been enfeebled by the Norman Conquest. The feudal ideas and customs, which also tended to limit the kingly power, were not allowed free play by William and his successors. So the Norman kings were not controlled by any regular constitution. But, despots though they were, they could not govern without assistance, and they thought it prudent to ask the advice of their most powerful subjects.

The Great Council. - The great council was the Norman form of the Anglo-Saxon witenagemote. The witenagemote had consisted of the chief officers of Church and State, and of such other persons as enjoyed the special confidence of the king. The great council still included the archbishops and bishops and greater abbots. Its remaining members probably sat as tenants-in-chief of the Crown. But the tenants-in-chief were extremely unequal in the extent of their lands, in power, and in dignity. Ordinarily it was only the greater tenants-inchief, the earls and barons, who were summoned to advise the king. On one or two occasions all the freeholders of the kingdom seem to have been assembled. Practically, the king summoned such of his tenants-in-chief as he thought proper.

The nature of the business transacted was much the same in the great council as it had been in the witenagemote. The consent of the great council was declared regularly in legislation, and occasionally in taxation. The 
great council debated questions of general policy, such as the determination of war and peace. It occasionally acted as the supreme court of justice in cases both civil and criminal.

But the debates of the great council seem to have been for the most part formal. There is no record of opposition offered by any party in it to the wishes of the king. The king might ask for their advice, but was not bound to follow it. The great council was weak, because it did not represent, either the whole body of Norman lords or the English nation. Still, the fact that the king summoned such a council, and professed to act by its advice, kept alive the feeling that he was not altogether absolute, and made possible the constitutional monarchy of later times.

The Royal Administration.-The new administration established by the Norman kings was one of the most striking results of the Conquest. We must, therefore, see who were the heads of this administration, and what was the work which they had to perform.

The Great Officers of State.-Under the Norman kings, the chief officers of the household, the steward, butler, and chamberlain, and the chief military officers, the marshal and constable, acted in the administration along with those whom we should call ministers. But these last, the justiciar, the chancellor, and the treasurer were even then the most powerful in the civil government. The office of justiciar became obsolete in the thirteenth century. In the eighteenth century the office of treasurer was put in commission. The duties of the chancellor have been almost entirely changed; so it becomes necessary to explain what these ministers had to do.

The Justiciar.-The justiciar held the first place among the ministers. Under William the Conqueror he acted as lieutenant and representative of the king when compelled to leave England. Under William Rufus he became a permanent prime minister, controlling the whole administration. Such he continued to be under Henry I. The office of justiciar was usually given to a clergyman, partly 
because the amount of business demanded high intelligence, and partly because a man who could not marry or found a family was less likely to take undue advantage of the power and wealth which it conferred.

The Chancellor.-The chancellor of the Norman kings was a very different official from the chancellor of later times. The chancellor of later times was a great judge, and his business was mainly judicial. The chancellor of the Norman kings was rather a secretary of state. With the help of a numerous staff of clerks, he carried on the royal correspondence, drew up the writs necessary for the administration of justice, and kept the royal accounts. Then, as now, the chancellor kept the royal seal. Edward the Confessor was the first of our kings who had a seal and a chancellor. The chancellor was always a clergyman, and one of the king's chaplains. His title is derived from the Latin term cancelli, signifying the screens behind which his assistants carried on their work.

The Treasurer.-The treasurer of the Norman kings had for his principal duty the safe keeping of the king's treasure. In those days there was no such thing as public credit. The most powerful kings could not raise a hundredth part of the sum which even small states can now borrow in the money market. Every king, therefore, kept by him a hoard of ready money. This hoard the treasurer had in his custody. But he had also a large share in the general business of government.

The Work of the Royal Administration.-Although the Norman kings established a strong administration, we must not suppose that this administration undertook more than one or two of the many tasks now laid upon a government. Its business may all be brought under the three heads of Finance, Justice, and War. It formed one permanent board, which was known by two different names, accordingly as the work in hand was financial or judicial. With reference to its financial duties, this board was known as the Exchequer (from the chequered cloth which covered the table round which the 
members sat). With reference to its judicial duties, the board was known as the Curia Regis (two Latin words signifying the king's court). In either case its members were the same; the great officers of State above mentioned, and such other persons as the king saw fit to join with them.

The Exchequer, we have said, was the department of finance. It sat twice a year, at Easter and at Michaelmas, to receive the payments made by the sheriffs, who were accountable, each for the revenue of his own shire. Three distinct records of the business were kept. One kept by the treasurer was known as the great roll of the Pipe (on account of its shape); another kept by the chancellor was known as the great roll of the Chancery; and a third was kept by an inferior officer of the king. One of the Pipe Rolls of Henry I. is still in existence, and is the source of most of our knowledge of Norman finance.

I. Norman Finance.-William the Conqueror and his sons were hard and greedy men. They knew that wealth is power. Wealth would enable them to lay by a store for times of difficulty, and to hire armies of foreign soldiers who cared neither for Norman nor for Englishman. The kings of England before the Conquest had been weak because they had been poor. Accordingly the Norman kings gathered in money by all means, fair and foul. They caused much misery by their extortion, but they defended the country from foreign invaders and from feudal rebels.

Domesday Book.-William the Conqueror understood the advantage which a government has in knowing the population and resources of the country. He took measures for drawing up what we might call a statistical survey of the whole of England. Royal commissioners were sent, in the year 1085 , into every shire, with orders to examine upon oath the sheriffs and the barons and their Frenchmen, and the persons attending the hundred motes, the priest and the reeve, and six men from every township. They were to inquire the name of every holding, who had it in 
the reign of Edward the Confessor, and who had it then; how much land was in every holding; how many slaves, serfs, and freemen were upon it; the extent of wood, pasture, and meadow ; the number of mills and fishponds ; and the value of the whole, both then and at the time of William's grant, and in the reign of King Edward. ${ }^{1}$

The chief sources of the revenue of the Norman kings were as follows :-

(I.) The Lands of the Crown.-We have seen that, even before the Conquest, there was a large royal demesne which passed to each king on his accession to the throne. This demesne was enlarged by the confiscations following on each of the many rebellions against William I. and his successors. The king might be said to be owner as well as ruler of all this land and of the towns upon it. So that he drew from the royal demesne all that a baron could have drawn from his private estate.

(2.) Feudal Revenue.-According to feudal ideas, the king was supreme landlord of the whole country. All the land of England was held of him. Those who held directly from him, the tenants-in-chief, owed him certain feudal services and payments. They were bound to appear in his court when called upon to give their counsel or to act as judges. They were bound to appear in arms with a number of followers proportioned to the size of their holdings whenever he summoned them to the field. But they also owed him a variety of dues or payments. When a tenant-in-chief died, his son could not enter into possession of the land until he paid the king a relief, as it was called, a sum afterwards fixed at five pounds for a knight's fee, and one hundred pounds for a barony. If the son were not of age when the father died, he became a ward of the king, who maintained and edu-

1 Here it should be noted (I) that the old system of local government is still in full force, and is used for the purposes of this inquiry; $(2)$ that this device of sending royal commissioners to take the depositions of local representatives is the germ of some of our most famous institutions, trial by jury and popular representation in Parliament. 
cated him, but took all the surplus revenue of the estate until he came of age. If the dead man left no son, but a daughter, she likewise became the ward of the king, who might choose a husband for her. If she were a wealthy heiress, the king often received a large sum from the man who wished for her hand. These were the rights of wardship and of marriage. Again, the tenant-in-chief owed to the king a class of dues known as aids. These customary aids which a lord could claim without consulting his tenants were three: a payment on the knighting of the king's eldest son, a payment on the marriage of the king's eldest daughter, and a payment to ransom the king if made captive.

Lastly, if a tenant-in-chief rebelled, the king took his lands from him. This was the right of forfeiture. If a tenant-in-chief died without heirs, the king succeeded to his land. This was the right of escheat, which still exists. It is easy to see that, if the king were greedy, he could extort a good deal by abusing these feudal rights. If he squeezed his tenants-in-chief, it was almost certain that they in turn would squeeze their tenants. In this way, although few men owed feudal dues directly to the king, the burthen of these dues was felt by the nation at large.

(3.) The Danegelt. - This was originally a tax of two shillings on every hide of land, and had been imposed by the English kings to provide the means of bribing or beating off the Danes. William I. took advantage of the threat of a Danish invasion in 1084 to re-impose the danegelt, and to increase it from two to six shillings the hide. Strictly speaking, all the land in the kingdom was liable to this tax ; but exemptions were granted in many cases.

(4.) The Ferm of the Shire.-The ferm (Latin firma) of the shire was a sum which each sheriff paid as a composition for a number of small items of revenue due to the king from his shire. These included the rents due for detached pieces of royal demesne, the king's share of the fines and fees accruing in the shire court, and sundry payments due from private persons or corporate 
bodies. After the Domesday Survey had been completed, all these items had been estimated at a fixed sum for each shire. For this sum the sheriff was answerable, whether his actual receipts were more or less. But he was allowed to deduct whatever expenses he had properly incurred on behalf of the king.

(5.) The Proceeds of the Pleas of the Crozun.-These comprise all the fees and fines derived from judicial proceedings which had been transferred from the courts of the hundred, or the shire, to the king's courts. For reasons which will be understood when we have spoken of the administration of justice, this class of proceedings was always becoming more numerous. The Norman kings made the administration of justice very profitable to themselves, partly by opening their courts freely to those who would pay for the privilege of pleading there, and partly by exacting heavy fines from wealthy offenders. The fines levied on offenders under the Forest Laws alone amounted to a considerable sum.

Lastly, we may notice that the Norman kings received large sums, both from persons who desired posts of dignity and profit, and from persons who wished to be excused from troublesome and unpaid public duties.

II. Norman Administration of Justice. - The administration of justice continued in many respects similar to what it had been before the Conquest. The local courts of the township, hundred, and shire were spared by the Conqueror. William Rufus abused the local courts for purposes of extortion. But Henry I. enacted that they should be held as in King Edward's day, and not otherwise. Many individuals and corporate bodies had courts of their own. But this peculiarity of feudalism had made its appearance under the later English kings. Lastly, the king was still the supreme judge of his people, and sometimes sat in person to decide civil or criminal cases of great consequence.

In spite of these points of resemblance, the Norman administration of justice came to differ more and more 
from the administration of justice among the AngloSaxons. The difference arose out of the encroachment of the royal upon the local courts. For this encroachment there were several reasons. The local courts, composed of untrained judges, could only administer uniform and simple customs with which every man was familiar. But the Conquest had broken up the customary law of the English, and had introduced many rules which only the Norman lawyers understood. Again, as feudalism advanced, the local courts were less and less able to enforce their decisions on powerful nobles. So the local courts became less and less equal to their work. Meantime the Norman kings were eager to bring business into their royal courts. There were two reasons for this eagerness; one was the wish to curb their powerful vassals, the very men whom the local courts could not curb ; the other was the wish to make money by fees and fines. In order to extend their jurisdiction the Norman kings used two instruments: the Curia Regis (king's court), and the circuits of royal commissioners.

The Curia Regis, we have already said, was composed of the same men who sat in the Exchequer. It tried cases in which the king was directly interested, cases in which the local courts had failed to do justice, cases between tenants-in-chief who were too powerful to submit to any other court, and cases which the litigants had been allowed as a special favour to bring thither for decision.

The Circuits of the Royal Commissioners were begun under Henry I., although they were not reduced to a system until the reign of Henry II. These royal commissioners were members of the Curia Regis, who travelled from county to county to administer justice. The county court assembled to meet them. The commissioners were trained lawyers, and had the authority of the king. The shire court consisted of men familiar with the facts in dispute, and men chosen from it were sworn to present criminals and to testify to matters in dispute. 
This great innovation had the most weighty consequences.

(I.) It was the origin of the circuits of the judges which gave England one law, and helped to strengthen English unity.

(2.) It placed the king in direct contact with the county courts, that is, with the great body of the people. Thus it set bounds to the power of the feudal lords, and prepared the way for the summoning of representatives of the people by the king.

(3.) By employing the sworn testimony of persons chosen from the neighbourhood, it prepared the way for trial by jury.

III. Norman Military System.-The Norman kings knew that it was dangerous to trust solely to their great vassals for military service. The Norman lords were brave, but unruly and untrustworthy. Therefore the Norman kings enforced the old obligation of the fyrd, the duty of every free man to do military service when summoned by the king. When the Norman barons rebelled, the Norman kings used the English militia to put them down. When Henry I. besieged the wicked Earl of Shrewsbury in his castle of Bridgnorth, the Norman lords wished the king to give him easy terms, but the English soldiers were eager to crush him altogether.

The Norman kings were rich, and could always hire soldiers from Flanders or Gascony, or some other foreign country. These men cared neither for English nor for Normans, but only for their employer. Thus the Norman kings had three kinds of military force.

Local Institutions.-The Norman Conquest did not affect local institutions so much as it affected the central government. The local institutions were deeply rooted in the affection of the English people, and they were cherished by the Norman kings as a defence against the feudal nobles. So the old assemblies and customs of the township, the hundred, and the shire were preserved under the Norman rule. 
But the Norman Conquest had an effect upon all those institutions. On the one hand, it gave an impulse to the growth of feudalism; on the other hand, it made the central authority more powerful and interfering.

The Township.-The township now became the manor. Its constitution became uniformly monarchical. The assembly of the cultivators became the court of the lord. The cultivators themselves were his tenants, in most cases not free tenants. The waste of the township was regarded as his waste; the assembly of the cultivators was regarded as his court. It is probable that this change had already advanced very far in most places, but it was completed by the Conquest.

The Hundred.-The hundred kept its old constitution, except in cases where manors were withdrawn from its jurisdiction by special privilege, granted either before or after the Conquest; but the business of the hundred courts seems to have become less and less important.

The Shire.-We have seen that the old constitution of the shire survived the Conquest. The principal changes due to the Conquest are found in the new position of the sheriff and the circuits of the royal judges.

The Sheriff.-In the early Anglo-Saxon constitution the ealdorman had represented the authority of the nation in the shire, and the sheriff had taken charge of the business of the king. In later times the ealdormen had been replaced by great earls ruling over many shires. After the Conquest the earls, with few exceptions, ceased to have any authority in the shires whence they got their titles. The sheriff remained as the king's representative in the county. As the king was nearly absolute, the sheriff was very powerful.

The sheriff had important duties as regards-I. Finance; II. Justice; III. War.

I. As regards finance, we have seen that he farmed the shire at a fixed sum for the year, and had to find this sum at his own risk. He had motives and opportunities for 
extortion. He often abused his office, and was accordingly unpopular.

II. As regards justice, he was the king's representative in the shire court; he sat there as president. As a royal judge, he sometimes tried cases which had been withdrawn from the local courts.

III. As regards war, it was the duty of the sheriff to summon the forces of the county. The great lords led their own retainers, but the sheriff led all the rest of the troops.

The Towns.-In the Norman period the growth of the towns was remarkable. Under the Anglo-Saxon kings the larger towns had become hundreds in themselves; the rest were mere townships. After the Conquest, all towns were regarded as part of the demesne of some lord, or of the king himself. The king or lord administered justice and received the revenue of the town. . The first object of the citizens was to limit the amount of taxation. In the Domesday Survey the amount due from each town is stated at a fixed sum. The next object of the citizens was to collect this sum themselves, so as to exclude the sheriff and his extortions. This they did by obtaining from the king a charter letting the town to them at a sum equal to that which they were liable to pay. For this they were answerable to the Crown alone, and this they apportioned among themselves. Those towns which were on the demesne of lords other than the king obtained similar charters from them. The towns also gained confirmation of their local courts of justice, and of their guilds for regulating trade and manufactures. All tried to approach as near as they could to the privileges enjoyed by London. London received from Henry I. a charter which gave it the position of a shire, authorised it to elect its own sheriff, freed the citizens from the jurisdiction of any court held outside their walls, and exempted them from tolls or port-dues throughout the kingdom. Yet even London had nothing which we should call a corporation. 
Relations between the State and the Church.William the Conqueror had professed himself the champion of the Church, and Pope Alexander II. had blessed his invasion of England. William was therefore ready to do for the Church all that could be done without weakening his own authority. He brought the Church of England into closer connection with the rest of the Church, filled the English Sees with Frenchmen or Italians, allowed the liturgy to be amended, and encouraged the celibacy of the clergy. In order to please the Church, he took one step of great consequence.

This was the separation of the civil and the ecclesiastical courts. Before the Conquest the bishop had sat with the sheriff in the county court. Justice had there been administered to laymen and clergymen alike. But now the bishops were to have courts of their own in which all spiritual causes were to be tried. Subsequently clergymen accused of crime were tried only in these courts. The law enforced in these courts was not the common law of England, but the canon law.

In order to control the clergy, William the Conqueror took the following measures:- He would not allow them to receive letters from the Pope which had not first been seen and approved by himself. He would not allow the bishops to enact new regulations for the Church without his consent. He would not allow a bishop to excommunicate any of his barons or servants for any offence, except at his own command; nor would he permit the Pope's legate to do anything in England, or even to land, without his license first obtained.

William also imposed, as far as possible, the same burthens on the lands of the Church as on the lands of laymen. The estates of the archbishops and bishops, and of most of the abbeys, were made liable for military service. In other ways he also taxed ecclesiastics to a great extent.

The Church was for a long time unable to contend with the Norman kings. The clergy were weakened by 
the fact that, whilst they were mostly English, their chiefs were usually foreigners, who had little fellow-feeling for them, and could not always speak their language. By degrees, however, the clergy became more united, and when the archbishops and bishops were once more chosen among Englishmen, they were regarded as champions of the people against the oppression of absolute kings.

Whilst William I. lived, the Church and State were at peace; but William II. plundered the clergy, as he plundered everybody else. He kept bishoprics and other preferments vacant for many years, and took all the revenue to himself. Sometimes he gave away the lands altogether. When at last he allowed the vacancy to be filled up, he took a heavy price for the permission.

When Henry I. came to the throne, he promised in his charter to respect the rights of the Church, and on the whole he kept his promise. But he had a dispute with the clergy, which is known as the dispute of investitures. The question was, who should invest the bishop with his office? The bishop was an officer of the Church, but he was also a baron of the realm. He was elected by the canons of the cathedral, but they had usually elected the person suggested by the king. After election the bishop received from the king the ring and crozier, the symbols of spiritual authority, and did homage to the king for the lands of his See. In this way the king practically controlled the appointment of bishops. Anselm, Archbishop of Canterbury, now wished to deprive the king of all power in the matter. Henry asserted his authority with great firmness. At last a compromise was attained. The ring and crozier were henceforwards to be given by the archbishop, but the king was still to receive homage for the lands.

The Classes of Society.-We are now able to take a general view of the classes of society during this period. The first great division is that which separates the Englishman from the Norman. The English are a conquered people; they have lost control over their course as a 
nation; the wealthy have lost lands, titles, and political power; the poor have been depressed much more deeply than before the Conquest. For the great majority of the English nation are now villeins, what we might call serfs. The villein is not indeed a slave. He has his own home and family. The law protects him from being slain or mutilated by his lord. He is tolerably safe in his holding, for the cultivators are too few for the land. If he lives on any of the estates of the Church, which are very extensive, he is not grossly maltreated. He takes part in the administration of his township. He has the chance of being set at liberty by his lord, or of escaping to a town for a year and a day, so as to become free, or of finding admission to the Church. Still his condition is hard and not honourable. For he is attached to the land and transferred with it. He is very imperfectly protected against the exaction or cruelty of his lord. He has no political rights, and he is despised by the free population.

Such was the condition of the mass of Englishmen. Three classes of Englishmen occupied a more favourable position. These were, first, the iree landowners, the socage tenants, as they are sometimes called; secondly, the inhabitants of the towns; thirdly, the clergy. These classes enjoyed complete personal freedom and ample powers of managing their own business. They did not yet possess (with the exception of the clergy) political power in the fuller sense of that term.

The Normans, on the other hand, are the ruling race. They have all that the English have lost-personal freedom, political influence, lands and titles, the great offices of Church and State. But the Norman power is weakened by the unceasing opposition of the nobles and the king. The king is determined to be a real ruler over all conditions of men; the nobles wish for license to do as they please. Under William I., William II., and Henry I. the nobles are held in check, and the most rebellious among them forfeit lands and honours. Under Stephen the nobles get their way, but only to destroy 
each other by the sword. At the end of this period the original Norman nobility is nearly extinct. The new nobility which takes its place is in a great degree English. Its best men are patriots, and become the leaders of the people in the struggle for freedom. 


\section{CHAPTER V. \\ HENRY II. AND HIS SONS, I154-1216.}

Introduction.-In the Norman period the king had gained almost absolute power; yet even this power had scarcely proved sufficient to restrain the feudal nobles. The civil war between Stephen and Matilda broke up the order sternly enforced by Henry I., and brought England to utter confusion. The nobles made war upon each other. The common people suffered cruel oppression. The Church was the only institution which passed through the period of anarchy uninjured. The very greatness of the evil, however, assisted its cure. The civil war swept away most of the Norman nobles. The people were eager for a king who would restore the reign of law. The clergy, now more powerful than ever, were on the side of peace and order.

Henry II. was not an Englishman, but he proved a wise king of England. He was able, industrious, and persevering. He had a love of system and was a great organizer and legislator. He was resolved to lessen the power of the nobles and to protect the commons. In doing this, he helped to efface the distinction between conqueror and conquered, to blend the Normans and English in one nation. The new nation made rapid progress in wealth and enlightenment under Henry's strong and prudent administration.

Henry's sons lacked their father's wisdom. Richard had some fine qualities, but was a knight-errant, not a statesman. He saw little of his people and left his ministers to tax them. John was far worse than Richard. He 
not only neglected his duty as king, but actively oppressed all classes of his subjects. So it came to pass that, for the first time since the Norman Conquest, all conditions of Englishmen united against the Crown. This, the first effort of the united English people to limit the royal power, gained the Great Charter of Liberties, which marks the commencement of a new era.

Accession of Henry II.-Henry began his reign with issuing a charter. In this charter he avoided any reference to Stephen, and promised to all his subjects the rights and privileges which had been confirmed to them in the charter of Henry I. He then entered on the work of government.

I. Policy of Henry II. with reference to the Nobles. - To reduce the power of the nobility was a principal aim of Henry II. He took back all the crown-lands which Stephen or Matilda had granted in the course of the civil war to the lords who supported them; he enforced the destruction of all castles built without the king's license. These measures met with some resistance; but, within two years, Henry brought all England into a peaceable condition.

Introduction of Scutage. - In order to reduce yet further the power of the feudal nobility, Henry adopted the plan of commuting (i.e., foregoing for a sum of money) his claim to the military service of his tenants-in-chief. He saw that the tenants-in-chief would gladly pay for their release from this troublesome service, especially if it involved their going abroad to defend some of the king's possessions in France. He saw, too, that if they were no longer called out for military service, they would lose something of their passion for war, and their followers would no longer be so closely bound to them. The money which he obtained in lieu of service would enable him to have professional soldiers, who would go anywhere and do anything so long as they were punctually paid.

Henry carried out this scheme on the occasion of the 
war of Toulouse in I I 59. He then excused his English tenants-in-chief from personal service on payment of a new tax, known as scutage-literally, shield-money. This innovation proved an effective means of weakening feudalism in England.

Henry took another means of weakening the nobles by compelling all men without exception to submit to the jurisdiction of the king's judges on circuit. Even those lords who had courts of their own, independent of the courts of the hundred or the county, had to attend the county court when it assembled to receive the itinerant judges. They had to admit and assist the sheriff of the county when he came into their jurisdictions in pursuit of criminals. Thus the people were taught that the king's justice overrode all special franchises or privileges.

II. Policy of Henry II. with reference to the Church.The Church had gained in power during the period of anarchy. It had been the only representative of law and civilisation; it had held the balance between the claimants to the crown; it had assisted in the restoration of order. The clergy were gradually recovering the unity which they had lost at the Norman Conquest. For many years after the Conquest the great offices of the Church were filled by foreigners, who were not popular with the inferior clergy; but now Englishmen began to rise in the Church. The higher and the lower clergy were now in sympathy. The clergy as a body were popular with the nation. Their popularity and power were at first useful to Henry in the work of settling the country; but, when he went on to make the Church feel the weight of his authority, the clergy began to resist. The leader of this resistance was Archbishop Becket, Henry's former chancellor and friend. Their first difference arose out of a question of taxation. In the year I 163 Henry wished to enroll as part of the royal revenue a tax of two shillings on every hide of land, which hitherto had been left at the disposal of the sheriffs, who received it. Becket objected to the change, and declared that nothing should be paid 
on this account to the king from the lands of the Church. This is the first instance recorded in English history of opposition to the will of the king with respect to taxation. Two other instances of such opposition are recorded in this period, and in both the refractory party was a prelate. We can thus measure the strength of the clergy.

Contest for Jurisdiction over Criminous Clerks. - A much graver conflict grew out of Henry's claim to jurisdiction over clergymen guilty of crimes. A few words of explanation may help us to understand this conflict.

At the present day justice is everywhere administered by the State. The courts are the Queen's courts; the judges are the Queen's judges ; the magistrates are named in the commission of the peace which is made out in the Queen's name. But before the Reformation things were very different. The Church had an extensive jurisdiction of her own. The Church courts were distinct from the courts of the Crown; they did not act in virtue of any royal commission, but claimed a totally independent authority.

The jurisdiction of the Church included the following cases:-

(a.) Certain offences against religion and morals, whether committed by clergymen or by laymen. Heresy and blasphemy, adultery and slander, may be taken as examples.

(b.) Offences against the duties of their profession committed by clergymen. As an example we may take the failure to perform divine service in the proper manner.

(c.) Criminal offences committed by clergymen, such as theft or murder. Before the Conquest clergymen would have been tried for these in the same courts as other accused persons. At the accession of Henry II. they were tried only in the Church courts.

It was the jurisdiction in the last class of cases which formed the subject of dispute between Henry II. and Becket. The spiritual courts could inflict only spiritual penalties, such as excommunication or degradation. It 
is true that a clergyman who had been degraded by a Church court for a criminal offence could be punished as a layman by a civil court for any crime which he might subsequently commit. Still he had practical impunity, at all events for a first offence. As a natural consequence, many grave crimes were committed by clergymen. Henry insisted that clerks who had committed crimes should, after degradation in the Church court, be handed over to his court to be punished like laymen.

Henry's demand seems to us quite just; but it is likely that the resistance of the Archbishop excited much sympathy. We must remember that clergymen formed a far larger proportion of the people than they do now. The so-called clerks included many persons who were not in holy orders, but had merely "taken the tonsure" (a peculiar way of wearing the hair), as a sign of their being destined to an ecclesiastical life. The dignity and the liberties enjoyed by the Church led thousands to take the tonsure who had no intention of proceeding to take orders. Probably the great majority of those who could read and write were clerks. At a later time all who could read might claim benefit of clergy (i.e., exemption from the ordinary punishment), if convicted of felony. Moreover; the Church was at this time regarded as the champion of popular liberty against royal oppression. Lastly, the criminal law, especially the law against forest offences, was exceedingly harsh. Many crimes were punished with death, blinding, or mutilation. Whatever softened the pressure of this harsh law may have been popular. Thus we may understand how the clergy were able to resist what seems to us the reasonable demand of so powerful a king as Henry II.

The Constitutions of Clarendon, I I64.-Henry was resolved to put the relation of Church and State into definite terms. He therefore held a great council at Clarendon in I I64, and laid before it the document known as the Constitutions of Clarendon. This document purported to be a statement of the law and custom hitherto 
prevailing in the kingdom with regard to the mutual rights of the king and the Church. Archbishops and bishops, and all ecclesiastical persons holding lands of the king, were to be subject to the same feudal burthens as the lay tenants-in-chief. Appeals from the ecclesiastical courts were to be made, in the first instance, to the king, and were not to be carried to Rome without his permission. Elections to bishoprics and archbishoprics were to be held in the king's chapel and with his consent, thus giving the Crown practically the power of appointing the prelates. Clergymen accused of crime were, in the first instance, to make answer in the king's court. They were then to be sent for trial to the Church court, and if convicted and degraded there, were not to be further protected by the Church. Archbishops and bishops were not to leave the kingdom without the king's license, and, if they left it, were liable to give security that they would attempt nothing to the detriment of the king and kingdom. No tenant-in-chief or minister of the king was to be excommunicated without the consent of the king, or, if he were abroad, of the justiciar. These, with other provisions of less consequence, were reluctantly accepted as law by the prelates in presence of the barons. Even Becket assented to them, although he afterwards withdrew his assent. If they had been carried out, they would have made the king supreme over the Church. Henry II. would have anticipated much of the work of Henry VIII. But the time was not ripe for the assertion of such power. In the struggle which ensued, Henry's mistakes and the murder of Becket gave the advantage to the clergy. Control over the election of bishops was renounced by John, although never quite lost to the Crown. The prohibition against appeals to Rome was neglected. The clergy contrived to withdraw themselves from the criminal jurisdiction of the State. In fact, Henry had claimed as current usage somewhat more power over the clergy than his ancestors had enjoyed, and was reduced to be content with far less. But the Constitutions of Clarendon are memor- 
able in English history as the first formal claim of the State to control the ecclesiastical authorities.

III. The Policy of Henry II. with reference to the Commons.-Henry II. gave to the great mass of the people the benefits of law and order. He did not confer many charters on towns, nor are the privileges specified in such charters as he issued very extensive, but he cherished the local self-government of the hundred and the shire, and gave it new consequence by developing the jury system. By establishing frequent circuits of royal judges and by reducing the powers of the sheriff, he protected the humbler class of freemen from much of the oppression which they had formerly experienced. In return, this class testified an unshaken loyalty to him. When many of the barons rebelled in favour of his eldest son, the common people, especially of the towns, took a foremost part in resisting the rebels.

IV. Policy of Henry II. with reference to Finance.The finances of the realm had fallen into the utmost disorder in the troubled reign of Stephen. Henry took the first steps to their improvement by restoring peace and by resuming the crown-lands, which had been lavishly granted away. He then gradually restored the financial system, which has been already described in speaking of the Norman period. The tax known as the Danegeld is mentioned for the last time in the year II62, but it was replaced with a new land-tax known as a carucage, from the term carucate, signifying the quantity of land that could be ploughed by a single team, the unit on which the tax was assessed. Henry, we have seen, was careful to exact his feudal rights from the estates held by prelates and abbots. He found a new source of wealth in the scutage, which has been already described; but the increase of his revenue was chiefly due to the prosperity of England under his prudent rule.

A great financial innovation marks the later part of his reign. Jerusalem had lately been taken from the Christians by Saladin. To furnish contributions towards the 
recovery of Jerusalem a tax known as the Saladin tithe was levied in the year II8r. It was a tax of one-tenth of every man's movables, the first instance in English history of a tax upon personal property. All direct taxation previously levied had been levied on land. We may conjecture that the taxation of movables points to a considerable progress in riches and luxury.

V. Policy of Henry II. with reference to the Administration of Justice. - In the course of the civil war between Stephen and Matilda the system of administering justice built up by the Norman kings had fallen into ruin. The king no longer held his solemn court on the great festival days; the Exchequer and Curia Regis ceased to act; the royal commissioners no longer went on circuit. To restore the ancient administration of justice was one of the first tasks of Henry's reign. But he did more than restore; he carried out reforms of which the effects may still be traced in England. These reforms may be grouped under three heads-(I) The development of the Curia Regis. (2) The improvement of the system of circuits. (3) The development of the jury system.

I. The Development of the Curia Regis. - The Curia Regis (King's court), once revived, again drew business from all the law courts. Its procedure was better suited to the needs of justice, its judges were expert lawyers, and it had power to enforce its decrees against the greatest in the land. Henry sometimes sat in person in the court to hear causes. In the year I I 76 we hear of eighteen judges employed in this court. In I 78 Henry appointed a committee of five judges to deal with all the ordinary business of the court, only reserving for the king's decision cases of peculiar difficulty or importance. Thus came into existence the court known as the Court of King's Bench, the oldest of the three courts of common law. It continued to exist down to the year I 873, when it was remodelled as the Queen's Bench Division of the High Court. But we must not suppose that Henry, by founding this court, parted with the royal power to administer justice in other ways. 
2. The Improvement of the System of Circuits.-The circuit system, begun by Henry I. and allowed to drop by Stephen, was revived and improved by Henry II. The business of the circuits was still financial as well as judicial. The judges went round the country to look after the king's revenue as well as to administer justice.

Henry enacted that every freeman should be bound to attend the county court when assembled to meet the king's justices, and that no special jurisdiction should exclude the sheriff from pursuing criminals and seizing them wherever he could find them. As the circuits of the judges became more frequent, the power of the sheriff declined. Both represented the king, but the judges, who came directly from the king, seem to have been more trusted by him. The sheriffs seem, also, to have abused their great power in the counties, and to have been very unpopular. In the year II70 Henry removed all the sheriffs throughout England. Under Richard I., in the year I I94, it was enacted that no sheriff should act as judge in his own county. In the great charter it was enacted that they should not act as judges at all.

3. The Development of the Jury System. - The origin of trial by jury is an obscure subject. We have seen that popular courts of justice existed among the Germans from the earliest time. But in these courts the assembled people acted as judges, not as jurymen; they decided questions of law as well as questions of fact. A jury decides questions of fact, and applies to the facts, when ascertained, the judge's statement of the law. Again, the English before the Norman Conquest made use of what is known as compurgation-that is to say, each party to a case brought a certain number of persons to swear to his truthfulness and honesty. The number was usually twelve. The compurgators have sometimes been mistaken for jurors, but they were really witnesses. Again, a law of Ethelred II. enacted that the twelve chosen thegns in each hundred should swear not to accuse any one falsely. This has led some people to suppose that 
the twelve thegns acted as a grand jury; but there is no evidence to show that this was the case. Upon the whole, we may conclude that what we call a jury was not known before the Norman Conquest. The story that Alfred established the jury system has no foundation.

Very soon after the Norman Conquest we hear of inquests, i.e., inquiries conducted by the king's officers, in which a number of persons supposed to have special means of knowing the facts are sworn to make a true report. It was by means of such inquests that the facts recorded in Domesday Book were ascertained. In the reign of Henry II. this expedient of sworn inquests was applied to strictly judicial purposes. Suits regarding the title to land had since the Conquest been determined by trial by battle. By the Grand Assize, an enactment of uncertain date, Henry provided that such suits might be determined by the verdict of a jury. Four knights of the county where the lands lay were to choose twelve knights of the neighbourhood, and these were to decide on oath which party had the better title. This is the first definite mention of a jury to decide civil suits.

The Grand Jury, to present or accuse criminals before the king's judges, owes its origin to the Assize of Clarendon, I 166. (The Assize of Clarendon must be distinguished from the Constitutions of Clarendon, passed two years previously.) The Assize of Clarendon enacted that twelve lawful (i.e. qualified) men in every hundred, and four in every township, should be charged to declare on oath before the king's judges whether there were any criminals in their hundred or township respectively. The persons named by them had to undergo the ordeal. If they failed under the ordeal, they suffered the punishment of their crimes. If they passed the ordeal, but were notorious bad characters, they had to leave the kingdom.

A council of the Church, known as the Lateran Council, held in 1215 , declared that trial by ordeal was unlawful. Trial by ordeal was consequently abandoned. In place of the ordeal, a second jury, the Petty Jury of modern 
times, was sworn to decide upon the guilt or innocence of persons accused by the Grand Jury. At first the Petty Jury, like all other juries, was composed of persons who were believed to have special means of knowing the facts of the case.

VI. Policy of Henry II. with reference to the Military System.-We have seen that the Norman kings had three different kinds of military force-the array of feudal tenants, the national militia, and the foreign soldiers whom they hired on occasion. We have seen that Henry II. preferred to take money rather than personal service from his feudal tenants. For his foreign wars he hired foreign soldiers. These he brought only once to England, during the dangerous rebellion of 1 I 73 , and then he dismissed them as soon as the war was over. The national militia he reformed by the Assize of Arms. This enactment, issued in II 81 , required every free man in the kingdom to provide himself with arms, differing according to the amount of his property. It also forbade any man to keep more arms than were needed for his equipment, or to export arms without the king's leave. Henry's care for the militia was part of the same policy with his neglect of the feudal force. He trusted in the loyalty of the great body of freemen to check the ambition of the nobles.

Result of the Reign of Henry II.-By these measures Henry more than repaired the mischief done in the reign of Stephen. He weakened the barons, protected the mass of the people, established good order throughout the kingdom; and made possible a new growth of commerce and riches. He raised the power of the Crown almost as high as it had been under his grandfather. And his authority was all the greater in England because England was only part of his possessions. He was not only king of England, but lord of Ireland, and ruler, under various titles, of one-third of what is now France. In extent of territory and in amount of revenue, as well as in ability and energy, he was the greatest prince of Western Europe. 
Although he died defeated and broken-hearted, it might seem that he had put the royal power in England beyond the possibility of dispute. Yet within twenty-five years of his death that power was placed under new and rigorous restraint.

Reign of Richard I.-The reign of Richard I. was barren of constitutional change. Richard was no statesman, neglected his people, and put them to heavy expense for his wars and his ransom. But he reaped the fruits of Henry's good government. The Crown was now too powerful to be resisted by any class. The ministers trained under Henry continued to govern under Richard, and governed as well as was compatible with extracting great sums from the nation. The barons admired and feared Richard as a great warrior. The clergy were grateful to Richard for fighting the battle of Christendom against the Mohammedans. The commons had peace and prosperity. Numerous charters conferring extensive privileges were granted to cities and towns. The system of inquest by juries was maintained and applied to new purposes, such as the determination of the king's feudal rights with reference to land in each shire. The power of the sheriffs was reduced by a rule that no sheriff should act as a judge in his own county. The office of coroner was created by an ordinance of I I94, which provided that in every county three knights and one clerk should be elected to keep the pleas of the Crown (placita corona).

Reign of John.-From the beginning of his reign John governed badly. He disgusted the barons by his illsuccess in war, and enraged them by the gross insults which he offered to their families; he laid heavy taxes on the whole nation; he was known as a cruel and sensual tyrant. Yet he might have long continued to misgovern England but for the course of events which brought him into conflict with the ablest and most powerful statesmen of that time, Philip Augustus, king of France, and the Pope, Innocent III. Philip Augustus took possession of almost all the French provinces which had 
belonged to the House of Anjou, and Innocent compelled John, who had quarrelled with the Church, to make the most degrading submission. Both of these events affected the course of English constitutional history.

Effects of the Loss of the French Provinces.-The loss of the French provinces had three important results. In the first place, the king of England was thrown upon the good-will of his English subjects. Secondly, the way in which those provinces were lost was so shameful to John, and proved him so destitute of warlike resolution or political wisdom, that those who might otherwise have submitted in despair were now emboldened to resist his oppression. Thirdly, the loss of Normandy cut off the descendants of the Norman conquerors from the land of their fathers. Thenceforward the nobles of England were Englishmen. The mingling of the two races which had been helped by the wisdom of Henry was perfected by the folly of John.

Effects of the Conflict with the Church.-John had rashly entered upon a struggle with Rome just at the time when the Papal power was greatest. By bringing down an interdict upon the kingdom, he caused much suffering to his subjects. Then he moved their anger by submitting at discretion, and acknowledging himself a vassal of the Pope. He had hoped to secure his power by reconciling himself with the Church. But this reconciliation began a series of events which ended in the issue of the Great Charter.

The Conflict of John with the Barons.-Having saved himself from a French invasion by submitting to the Pope, John wished to raise an army for the recovery of his French provinces. The barons of the north of England declared that they were under no obligation to serve abroad, and refused to go with the King. At the same time a great council was held at St. Albans to ascertain the satisfaction due for losses incurred by the clergy during the recent dispute between John and the Pope. Promises of reform were made there by the justiciar on 
behalf of the King. But the most curious circumstance about this council was the attendance of four representatives from each of the townships on the royal demesne, the first example of the representation of even a part of the commons at a great council. Later in the same year another council was held in St. Paul's, London, where the Archbishop, Stephen Langton, produced the charter of Henry I., and exhorted his hearers to require its observance by the King. Later still, the King called another council, and issued a summons directing the sheriffs to send up four discreet knights from each shire to speak with him concerning the affairs of the realm. This would have marked a further step towards the representation of the commons, but we do not know whether this council ever met.

During the greater part of the year I2I4 John was absent in France. The barons who had refused to go with him met at St. Albans, and agreed to present their demands to the king after Christmas. John tried to gain over the clergy by granting them that freedom of election which Henry II. had refused. When the barons presented their demands in the beginning of the year I 215 , he asked and obtained a respite until Easter; but, as he would not then give satisfaction, the barons marched southwards to London, where they were welcomed by the citizens: John found himself almost alone, and, by the advice of his few friends, accepted the articles offered by the barons. On the I 5 th of June I 215 he set his seal to the Great Charter.

The Great Charter, 1215. - The whole of the constitutional history of England, it has been said, is a commentary on this charter. It consists of sixty-three articles, which differ greatly in length and in importance, and which are not arranged in any regular order; but its principal provisions may be brought under a few heads.

I. The Church.- John, we have seen, had already granted freedom of election to the clergy. He now confirmed the grant, thus parting with a power which his 
predecessors had enjoyed since the Conquest. He also confirmed to the Church all her other liberties. The barons could not ask less for the clergy who had supported them, and John could not offer less, as he depended on the assistance of the Pope.

II. The Tenants-in-chief.-The king undertook not to abuse his feudal rights, so as to extract from his tenantsin-chief more than was due. (I.) No tenant-in-chief was to be called upon for more than the regular service. (2.) Upon the death of the tenant, his heir was to succeed on payment of a fixed relief. (3.) If the heir was a minor, the king was to act honestly as his guardian, not taking more than the customary payments and services from those who lived upon the estate, nor wasting the buildings and enclosures. (4.) If the king chose a husband or wife for the heir, he was to choose a person of suitable rank. The king was not to compel any widow to marry. (5.) No scutage or aid was to be levied without the consent of the common council of the realm, except in the three customary cases-to ransom the king's person, to marry his eldest daughter, and to make his eldest son a knight.

When the consent of the common council of the realm was required for an extraordinary aid, the king was to summon all his tenants-in-chief; the archbishops, bishops, earls, and greater barons singly by letters addressed to each, and the other tenants-in-chief by a general summons sent to the sheriff of each county. Forty days' notice was to be given, and the place of meeting and the causes of summons were to be expressly stated.

III. The Rights of Cities and Towns.-To London, and to all other cities, boroughs, and ports, the king guaranteed all their ancient liberties.

IV. Administration of Justice.-The king promised (I) that the administration of justice should no longer be made a source of gain to the Crown. "To no man will we sell, to no man will we deny or delay, right or justice." (2) That no man should be punished without due trial. "No free man shall be taken, or imprisoned, disseised, or 
outlawed, or exiled, or in any way destroyed, nor will we go upon him, or send upon him, save by the lawful judgment of his peers or the law of the land." This clause contains the germ of the right to trial by jury, and of the right to speedy trial confirmed by the Habeas Corpus Act. (3) That unreasonable and oppressive fines should no longer be imposed. Fines were to be proportioned to the offence, so as not to take from the freeholder his land, from the merchant his merchandise, or from the villein his wainage (i.e., farming stock). (4) That suitors who came to have their private disputes determined in his court should not be put to the inconvenience of following him wherever he happened to be. Such suits (called common pleas) were to be heard in some fixed place. This led to the establishment of a new branch of the king's court, distinct from the King's Bench, and known as the Court of Common Pleas. This, the second court of common law, continued to exist until the year I873. (5) That the judges should go circuit four times a year to decide questions of title to property.

V. The Forests.-All forests made since the accession of John were to be disforested. In every county twelve knights were to be chosen and sworn to inquire into the evil customs in force in the forests. All such customs reported by them were to be annulled within forty days.

VI. Miscellaneous.-(I) In time of peace all merchants were to be free to come to England; to stay in England, and to leave England without being subjected to extortion of any kind. (2) No servant of the king was to take the horses or carts of any free man for the king's service without the owner's leave, or to take the corn or goods of any man without paying for them. (3) One system of weights and measures was to be established throughout the kingdom.

The charter concludes with a singular provision intended to secure its observance. The king empowered the barons to choose twenty-five of their number to watch over its observance. Any four out of the twenty-five 
might demand redress for any infringement of the charter from the king, or, if he were absent, from the justiciar. If redress was not granted within forty days, the twenty-five barons were authorised to put constraint upon the king by seizing his lands and castles, or by any other means, saving always the liberty of himself, his queen, and children.

Observations upon the Great Charter.-The following points deserve especial notice:-

(I.) The demand for the Great Charter was made virtually by the whole nation. The barons took the leading part, but they were supported by London and the other towns. In former times the common people had supported the king against the barons; they now supported the barons against the king. From this fact we may infer how much Henry II. had weakened the power of the nobles and increased the power of the Crown. We may also infer that the barons were now fighting for the interest of the whole nation, not, as in former times, for their private advantage. The clergy could not openly take part with the barons, for John was now a vassal of the Pope, and under his protection. But Archbishop Langton had helped the barons to put their grievances into a precise form, by suggesting that they should ask for the observance of the charter of Henry I. There is little doubt that the secret sympathy of the clergy was with the people. Even the few English nobles who followed John to the last approved of the Great Charter.

(2.) As the barons were speaking for the nation, so they demanded justice, not for themselves only, but for all conditions of men. By the Great Charter all the privileges which the king granted to his tenants-in-chief were to be granted by the tenants-in-chief to their vassals. All free men were ensured against injustice and oppression. Even for the class which was not free, the villein class, it was provided that their stock should not be taken by way of fine. The freedom promised to the towns and the lessening of the royal forests were especially beneficial to the middle and lower classes. 
(3.) Although John said that to grant the demands of the barons would be giving away his crown, their demands were remarkably moderate. They made scarcely a single demand for which there was not a precedent. Their scheme of redress was based upon the charter granted by so despotic a prince as Henry I. They did not endeavour to set up a new constitution. They only asked for righteous government on the old principles. It is true that John drove them to ask with arms in their hands, and that the precedent of successful resistance to the king had immeasurable consequences. But the barons had not resorted to force until John convinced them that they would not get redress in any other way.

(4.) The Great Charter left the King still supreme in the state. It was only for the purpose of obtaining an extraordinary aid that the King was bound to summon a great council. This great council, too, was strictly on the feudal model. It was to include all the tenants-inchief, and the tenants-in-chief only. Such a council was rarely called either before or after the date of the Great Charter. It would have been too large for business and too narrow for representation. The kings of England had usually summoned only their greater tenants to advise them in council. Only the greater tenants were entitled, under the Great Charter, to a separate summons. The barons found in the next reign that, if they were to curb. the king, they must associate with themselves the representatives of the commons. In the struggle for the observance of the Great Charter the English Parliament had its origin.

Death of John.-John had issued the charter under compulsion, and did not intend to keep his word. Having been released from his obligation by the Pope, he proceeded to make war upon the barons. In despair they invited Lewis, the eldest son of Philip Augustus, to become their king. Lewis invaded England. Whilst the war was yet undecided John died, leaving an heir only nine years old. 


\section{CHAPTER VI.}

HENRY III. AND EDWARD I., I216-1307.

Introduction.-The rise of our modern Parliament forms the chief interest of the eighty years following the grant of the Great Charter. There could be no security for the fulfilment of the promises contained in that charter until the nation had a permanent organ to express its grievances and to enforce redress. John's son and successor, Henry III., was always ready to confirm the charter for a consideration; but no sooner had he confirmed than he began to violate it again. The barons often renewed against the son the combination which had proved so successful against the father; but their great chief, Simon de Montfort, Earl of Leicester, found by experience that such combinations rested on too narrow a basis, and were ever liable to be dissolved by personal jealousy. By carrying out the principle of representation which was already familiar to Englishmen, he tried to enlist the active support of the people in his struggle with the King. Although he was unsuccessful, the precedent which he set was copied by his adversary. Edward I., the wisest statesman of the Plantagenet line, saw that a king who could rule with the co-operation of his people would be greater and more powerful than a king who ruled alone. He wrought out a Parliament representative of the three estates of the realm, and of the local communities into which it was divided. From his death down to the Reform Act of 1832, Parliament altered little in outward form, however it might vary in actual power or in the relations between its various parts. The English 
Constitution, as we know it, may be said to date from the reign of Edward $I$.

In tracing the rise of Parliament, we must always remember how vast had been the power of the Crown. We must not imagine that, because the Great Charter required the consent of the tenants-in-chief to taxation, the power of the Crown was at once much lessened. On the contrary, the king continued to be the actual ruler of the country. The whole system of administration centred in the king. He determined the policy of the state, chose and dismissed ministers, was the captain of the national forces, the fountain of justice, and even the supreme legislator. $\mathrm{He}$ had tradition on his side, for his predecessors had been almost absolute. He had public opinion largely on his side, for all wise men felt that England needed strict government. He had the lawyers on his side, for the lawyers knew that his authority and their influence had the same bounds. He had the Pope on his side, for the Pope would not allow any other power to interfere with his vassal.

The Early Years of Henry III.-The death of John saved England from a serious danger. Englishmen had no longer any sufficient reason for supporting a foreign prince. The regent Pembroke and his advisers immediately republished the Great Charter. The clauses relative to taxation, the great council of the realm, and the forests were indeed omitted, but only until there should be time for fuller consideration. After this politic measure the English friends of Lewis gradually fell away from him. His army was routed at Lincoln and his fleet was destroyed off Sandwich. By the treaty of Lambeth, Lewis agreed to withdraw from England, and his English adherents made their peace with the regent. The Great Charter was then republished a second time, the forest clauses of the original, which had been omitted in the first republication, now appearing as a separate charter, the famous Charter of the Forests. The Earl of Pembroke as regent, and, after his death, Hubert de Burgh 
as justiciar, governed the kingdom with prudence and courage. Only after Hubert's fall in 1232 did the civil strife recommence.

Misgovernment of Henry III.-Henry's misconduct forced the nation to renew its resistance. Henry was weak, shifty, and extravagant. He wanted a great deal of money for his own purposes, and he allowed his foreign favourites and the Pope to take a great deal more for themseives. Thus there were three chief reasons for discontent. The whole nation resented his wasteful expense and lax government. The nobles hated his foreign favourites, who got honours and offices, castles and estates. The clergy were angry because the Pope filled up English benefices with Italian priests, and taxed the English Church in order to have money for his political projects in other countries. All these feelings of dissatisfaction found vent in a long series of disturbances.

Henry forced to make Concessions.-Henry was in such constant want of money that he was reduced to make offers that would have amazed his ancestors. In I 237 he proposed that the great council should not only settle the best manner of collecting an aid, but should also appoint a commission to see that it was properly expended. In 1238 he offered to submit himself to the decision of a commission of fifteen elected to reform the kingdom. In 1254 his queen and his brother, acting as regents during his absence in Gascony, summoned to a great council at Westminster four knights chosen by each shire and representatives of the clergy of each diocese. This seems to have been the first occasion on which representatives of the shires actually sat in a great council. But though Henry might promise much and perform somewhat, he always gave fresh grounds of discontent.

The Provisions of Oxford, 1258.-In I 258 the national discontent was at its height. The great council assembled at London in April refused any supply until the king should have assented to all their demands. They re- 
quired that twenty-four commissioners should be chosen, half by themselves and half from the royal council, to carry out all the necessary reforms before Christmas. The king consented to this proposal and the Parliament was adjourned to Oxford.

The Parliament re-assembled at Oxford in June. The barons appeared in arms, and the disorder of the proceedings gained for the assembly the name of the Mad Parliament. The barons set forth their grievances, which show that most of the articles of the Great Charter were constantly disregarded. The committee of twenty-four was then appointed. It proceeded to draw up a new constitution known as the Provisions of Oxford.

It established a standing council of fifteen to advise the king in all affairs of state, and to control all ministers and public officers. The council was to confer thrice a year with a committee of twelvo chosen the whole body of barons, to discuss public business. By this means the barons hoped to control the king, and at the same time to save themselves from the burthen of frequent attendance in the great council of the realm. But the constitution which they had devised was faulty in two respects. First, it was too elaborate; and, secondly, it was too narrow. It was not sufficiently representative.

The Provisions of Westminster, 1259.-In the following year the barons, pressed by the king's son Edward, produced their measures for the redress of grievances, known as the Provisions of Westminster. They were a supplement to the Provisions of Oxford. Perhaps the most important article was that regulating the appointment of the sheriffs. The county court was to elect four knights, and of these one was to be chosen by the barons of the Exchequer to be sheriff of the county. This regulation would have put all the military and financial administration of the counties in the hands of the popular party; but we do not know if it was ever carried into effect.

Continued Discontent.-England still continued in a restless condition. Henry did not really wish to carry 
out reforms which had been imposed upon him by force, and which limited his power. He rather sought to sow division among the barons. So far as can now be discovered, the barons were divided into two parties, that of Simon de Montfort, Earl of Leicester, and that of Richard de Clare, Earl of Gloucester. Simon was anxious to enlist the support of the people in the conflict with the king. Richard desired to limit the king's power, chiefly in the interest of the barons; but in I26I both agreed to hold an assembly at St. Albans, to which four knights were summoned as representatives of each shire. Henry heard of this summons, and at once ordered the sheriffs to send these knights, not to St. Albans, but to Windsor, where he meant to hold a council. Thus did the principle of representation gain ground through the conflict of the king with the barons.

Arbitration of the King of France.-The king and the barons at length agreed to refer their disputes to the arbitration of Lewis IX., king of France. Lewis published his award, commonly known as the Mise of Amiens, in January I264. He annulled the Provisions of Oxford, and all measures founded upon them; but he added that this decision was not to derogate from the liberties of the realm as established by charter, law, or custom, and that no punishment should be inflicted upon any person who had taken part in the late troubles.

The Barons' War and De Montfort's Parliament.By this award matters were brought back to the state in which they had been after the granting of the Great Charter. As the Great Charter had not hindered Henry from misgoverning the country for many years, the barons could not be expected to accept the award. Arbitration having failed, recourse was had to arms. On the $14^{\text {th }}$ of May the barons gained the battle of Lewes, and took prisoner Henry, his son Edward, and many of his principal supporters.

The king was now compelled to accept the terms of the barons. The treaty between them was known as 
the Mise of Lewes. In the Parliament held soon after there sat four knights from each shire. We have here the second instance of the representation of the counties. This Parliament sanctioned a new scheme of government. The barons were to choose three electors, and these were to choose nine councillors, by whose advice the king was to be guided. These councillors were to be all native Englishmen.

But this new government was in a very precarious condition. The queen was collecting forces in France to invade England. The king and his friends waited only for their coming to take up arms. Simon de Montfort therefore summoned another Parliament to meet in January I265. To this Parliament he summoned only those prelates and barons who were of his party; but he summoned for the first time representatives of cities and boroughs. This was the famous Parliament of Simon de Montfort, wrongly stated to have been the first representative Parliament. We have already seen instances of representation of the shires. It was not till thirty years later that the right of cities and boroughs to representation was fully established. Nevertheless Simon de Montfort's Parliament marks a memorable step in advance.

Simon's great service to the people of England did not save him from defeat and death. The jealousy of Gilbert, the young Earl of Gloucester, and the ability of Edward prevailed. Simon fell in the battle of Evesham, fought on the 4 th of August I 265. His followers resisted some time longer. But the Barons' War was virtually ended by the ordinance known as the Dictum de Kenilworth, from the castle which was the last to surrender to the king. By this ordinance the acts of Earl Simon were annulled, but the king's obligation to keep the charters was acknowledged. Henry was now old, and had learnt wisdom from adversity. He died in peace six years after the publication of the Dictum de Kenilworth.

Accession of Edward I.-When Henry died, Edward was still absent in the Holy Land. $\mathrm{He}$ was, however, 
recognised as king without delay. For the first time the oath of fealty was taken to a king who had not yet fulfilled the ceremony of election and coronation.

Policy of Edward I.-Edward aimed throughout his reign at two principal objects-to complete the English conquest of Britain, and to perfect the institutions of England. Only the second of these objects concerns us here. As a constitutional reformer, Edward presents two aspects to the student of history. In one aspect he resembles Henry II. $\mathrm{He}$ is a wise, industrious, persevering ruler, resolved to remedy the evils caused by the weakness of his predecessor and to guard against their recurrence by fortifying the royal authority. Like Henry II., Edward wished to control the clergy, to keep the nobles at peace, and to protect the commons. But they differed much in their circumstances. England was barely half of Henry's dominions. Edward's dominions outside England added scarcely anything to his strength. Again, the condition of England at the accession of Henry II. was such as to make an absolute ruler necessary. England at the accession of Edward I. had become capable of constitutional government. Edward was sagacious enough to perceive the true state of affairs, and to frame his measures accordingly. And this brings us to consider him in his other aspect as the friend of constitutional freedom and the creator of the English Parliament. In this aspect Edward appears as the successor of Simon de Montfort. He reduces to a system what Simon de Montfort had time only to suggest. The spirit of freedom, thus fostered by Edward, at length became strong enough to obtain from him the celebrated Confirmation of the Charters in 1297.

We have first to consider Edward's policy towards the various classes of his subjects and in the different departments of the State.

I. Policy of Edward I. with reference to the Nobles.Edward had not forgotten the Barons' War. He wished to lessen the power of the feudal chiefs. One expedient 
adopted by him for this purpose was the inquiry known as Quo Warranto? (By what title?). The power of the barons consisted partly in their franchises-that is, in their right to jurisdiction over certain places and districts. In 1278 Edward obtained the passing of the Statute of Gloucester, which ordered the itinerant justices to inquire by what title the lords held their franchises. The inquiry was made with such severity as greatly to disgust the barons. Earl Warenne, when asked for his title-deeds, produced a rusty sword, and said, "By the sword my forefathers gained their lands, and by the sword I will keep them." Edward took the hint, and refrained from pushing the investigation too hardly.

Another expedient used by Edward for the same purpose is known as distraint of knighthood. He ordered all freeholders possessed of an estate of $£ 20$ a year (equivalent to $£ 300$ a year at present) to receive knighthood, or to pay heavily for not doing so. This was partly a device to raise money, but its chief object was to lessen the consequence of the great lords by increasing the number of persons who enjoyed knightly rank and did service as knights in the field.

A third expedient for the same purpose was provided by a statute made in I290, and known as the "Statute Quia Emptores" (from the first words of the Latin text), which modified the feudal system of tenure. Formerly the man who received land of another became his feudal dependent. In future he was to become the feudal dependent of the lord of the person who transferred the land. Thus, if a tenant-in-chief granted an estate to a friend, that friend became not his dependent, but a dependent of the king. The result would be to increase the number of persons holding directly from the king. The superior lords had been gratified by the enactment of another statute of the year I 285, known as the "Statute De Donis Conditionalibus" (Latin for "concerning grants made on a condition"), which made entails perpetual, and so hindered the buying and selling of land. 
II. Policy of Edward I. with reference to the Church. -Edward sought to limit the wealth and power of the clergy, and to make them contribute their full share to the revenue.

The Statute of Mortmain, passed in I279, enacted that henceforward land granted by any man to the Church should be forfeited to his lord, or, if the lord failed to enforce his claim, to the king. The reason for this statute was as follows:-The Church already possessed vast estates. These estates were always increasing. The more the lands of the Church grew, the less became the feudal revenue of the king and barons; for the feudal rights of relief, wardship, marriage, escheat, and so forth, could not take effect in the case of corporate bodies like cathedrals or monasteries. A man sometimes granted his land to a monastery on the understanding that the monastery would then let it to him, so that he would have it free from feudal burthens. Hence the need for a statute of mortmain. A license to grant land in mortmain might be obtained from the king, but the king would be sure to make a charge for granting such a license.

The jurisdiction of the Church courts was limited in 1285. These courts were constantly trying to bring more and more cases under their jurisdiction. Edward enacted that, besides the spiritual or moral causes formerly mentioned, they should have jurisdiction only in causes arising out of wills or marriages. This enactment, however, did not affect the right of the Church courts to try clergymen accused of crime.

The taxation of the clergy led to a serious conflict. In 1296 Pope Boniface VIII. issued a bull by which he forbade the clergy to pay taxes to the secular authority. In the next year, when Edward asked for a contribution from the clergy, they replied that they dared not disobey the Pope. Edward resolved that if they would not contribute to the expenses of government, they should not have the protection of government. He put them beyond the pale of the law. They could get no redress for wrong 
done to them, but had to give redress for every wrong done by them. This proved so disagreeable, that they submitted to pay.

III. Policy of Edward I. with reference to the Commons.-Edward I., like Henry II., was the benefactor of the commons, in so far as he established order and a strict administration of justice. But the greatest service which he rendered to the commons lay in giving them a place in Parliament and a regular system of representation. This subject, however, can be better discussed when we come to speak of the Parliament as a whole.

IV. Policy of Edward I. with reference to Finance.Edward was not, like his father, a spendthrift, but his far-reaching schemes of foreign policy involved a heavy expenditure. The Great Charter had put a stop to many of the exactions formerly practised. It was difficult to raise large sums on credit. Accordingly, Edward sometimes had recourse to new and arbitrary ways of getting money. In 1282 he seized for the Welsh war the treasure which had been collected in the Temple at London for a new Crusade. In I 294 he seized all the treasure of the monasteries and cathedrals. In the same year he seized all the wool, then the most valuable export, and only returned it to the merchants on their paying from three to five marks the sack. In 1297 he again seized all the wool, and exacted still more severe terms for its restoration. These violent measures helped to feed the discontent which broke out in the later part of his reign.

V. Policy of Edward I. with reference to the Administration of Justice.-We have already seen how the Court of King's Bench and the Court of Common Pleas became detached from the old Curia Regis. The Exchequer continued to exist as a court for trying cases which concerned the king's revenue. From the time of Edward I. these courts became quite distinct from and independent of each other. Each had its own head; the King's Bench and the Common Pleas having Chief Justices, and the Exchequer a Chief Baron. In this form they continued 
to exist down to I873. From the time of Edward I., too, these courts were confined to strictly judicial business, and had no share in the work of the supreme administration. We need not therefore trace their history further. But the king did not cease to administer justice. He was still supposed to afford a remedy for any wrong which, for any reason, the ordinary courts failed to redress. Persons who thought themselves aggrieved might petition the king. The king might of his grace redress their grievances. Such petitions passed through the hands of the Chancellor. In the next century the Chancellor was intrusted with the business of deciding upon them, and thus arose the Court of Chancery. In dispensing justice the king was assisted by a new body of advisers, somewhat resembling the ancient Curia Regis. It included the great officers of the household and of the government, the judges, and such other persons as the king chose to advise him. In later times this body became the Privy Council and gained a great place in the government of England.

VI. Policy of Edward I. with reference to the Military System.-Edward was frequently engaged in war, and had need of all the military resources of the kingdom; but he did not hire foreign soldiers, as Henry II. had done. By the Statute of Winchester, passed in 1285, he revived Henry's Assize of Arms and provided for the efficiency of the militia. By the distraint of knighthood he tried to compel wealthy freeholders to serve as heavy cavalry irrespective of the tenure on which they held their land. In 1297 he tried to make a general levy for service on the Continent; but this oppressive measure provoked resistance and had to be abandoned. In military matters, as in every other branch of government, Edward was disposed to ignore feudal ideas. He did not place his trust in the tenants-in-chief and their followers; he rather sought to avail himself of the strength of the nation at large.

We have next to consider the completion of the English Parliament by Edward I.

Tentative Parliaments.-From the beginning of his 
reign Edward had called Parliaments; but these Parliaments differed much in their constitution. The Parliament of 1275 is said to have contained, beside prelates and barons, "the community of the land," meaning representatives, at least of the shires, if not of the boroughs also. In I 283 Edward wanted money for the Welsh war. He was himself in Wales with most of the barons. He therefore took the unprecedented step of calling two councils-one at York, of persons belonging to the province of York, and another at Northampton, of persons belonging to the province of Canterbury. At these councils only the representatives of the clergy and the commons were present. Later in the same year he assembled a Parliament to witness the trial of David, the Welsh prince, who had raised a rebellion. To this Parliament he summoned the barons, two knights from every county, and two citizens from each of twenty cities or boroughs. The clergy were not summoned, because they were not expected to be present at the trial of a capital case. In I 290 E.dward summoned at first only the bishops and barons, and, after they had sat for some time, summoned the knights of the shires. Thus we see that until the middle of Edward's reign there was no fixed constitution of Parliament. So long as the king observed that clause of the Great Charter which required for an extraordinary aid the consent of the tenants-in-chief, he might take counsel with various classes of his subjects as he thought proper. The right of the commons to be consulted on public affairs had been several times acknowledged, but was not yet become an essential part of the constitution.

The Model Parliament of 1295.-But the circumstances of the time were all working in favour of the commons. Edward was anxious to curb both the nobles and the clergy; he therefore sought for a counterpoise to both in the power of the third estate: Edward was often in want of money; he therefore looked for a supply from the merchants of the towns and the smaller land- 
owners in the country who had prospered under his strong government. Confident in his own powers as a statesman, he hoped to strengthen the royal authority by obtaining the co-operation of the people. Methodic and legal by nature, he wished to bring the great council of the realm to a well-considered and permanent form. Accordingly, in 1295, he summoned the first complete English Parliament. As of old, he addressed a special summons to the prelates and barons, but he directed the archbishops and bishops to bring with them representatives of the inferior clergy, namely, one proctor for the clergy of each cathedral, and two proctors for the clergy of each diocese. He directed the sheriffs to cause to be elected two knights from each shire, two citizens from each city, and two burghers from each borough. Thus was formed a full Parliament of the three estates of the realm. Subsequently, indeed, the representatives of the inferior clergy ceased to attend, but from this time forward the representation of the commons was never interrupted.

The Confirmation of the Charters.-It remains to notice the final confirmation of the charters in the year 1297.

Edward's needs had for some time been very urgent. A war with France and a war with Scotland required supplies of men and money which England was not willing to furnish. In the beginning of the year Edward had put the clergy beyond the pale of the law for refusing to contribute to his expenses. He then assembled the barons and demanded their assistance in the French war. He proposed that Roger Bigod, Earl of Norfolk, and Humphrey Bohun, Earl of Hereford, who were respectively marshal and constable of England, should lead the army in Gascony whilst he took the command in Flanders. They refused, on the ground that their tenure did not bind them to serve abroad, except with the king. The assembly broke up in tumult. Edward then resolved to act for himself. He seized the wool of the merchants, ordered every county to supply provisions for the army, and summoned all the landowners of the kingdom to 
hold themselves in readiness for service abroad. He next reconciled himself with the clergy. The marshal and the constable collected their friends, and drew up a statement of the public grievances. Edward gave an evasive reply and embarked for Flanders.

As soon as Edward was gone, the marshal and constable marched on London. The citizens joined them. Edward's eldest son, who was left as regent, summoned a great council. In this council the marshal and constable presented their demand for the confirmation of the charters with supplementary articles. Young Edward gave way, and sent both the confirmed charters and the new articles to Ghent for his father's confirmation. Edward gave this confirmation on the 5 th of November.

The new articles have come down to us in two forms, one Latin and the other French, which differ in several respects. The French form is supposed to be the more authentic. Its most important clauses are those which provide that Edward's recent exactions should not be taken as a precedent, and that no taxation other than the ancient and customary "aids, prises, and customs" should be levied by the king without the common consent of the realm.

The consent of Parliament was recognised as necessary to the imposition of any new tax.

From the day when the barons rose in arms against John to the day when Edward confirmed the charters, the struggle to limit the royal power had never ceased, although it was sometimes suspended. The Great Charter had expressed the wishes of the nation, but those wishes had been in great measure ineffectual, because the nation had no permanent organ of its will except the king. For his arbitrary power, which could act at any moment, a check which could act rapidly and surely was required. This check was found when the feudal assembly of prelates and barons was merged in the Parliament of the three estates. The latest confirmation of the charters was worth all the others, because there was now a constitutional authority to watch over its observance. 


\section{CHAPTER VII.}

THE LATER PLANTAGENETS, I307-I 485.

Introduction. - The confirmation of the charters in I 297 marks an epoch in our constitutional history. From that date down to the death of the last Plantagenet king, the constitution of England was but little modified in form, although it underwent gradual change in substance and in spirit. Such change was due less to express legislation than to the silent growth of society. The decline of zeal and energy in the Church, the bloody civil wars, which thinned out the old baronial families, the rising wealth, intelligence, and power of the middle class, the discontent of the peasantry, and the decay of villeinage, all reacted upon the constitution of England, and had more influence than statutes or charters upon its further development.

The middle of this period is marked by an increase in the power of Parliament, especially of the House of Commons. So long as our kings reigned by an unquestioned title, Parliament had to sustain a severe struggle against the prerogative of the crown; but Richard II. was the last Plantagenet who could boast such a title. Henry IV. and his descendants ruled, not by hereditary right, but by the will of the people. Kings by a parliamentary title, they were obliged to conciliate Parliament. Hence Parliament gained a great accession of power under the kings of the House of Lancaster; ' but this power was short-lived. The Wars of the Roses destroyed the strength of the lords. The growth of new religious 
opinion weakened the clergy. The commons, no longer finding leaders in the other Estates of the realm, were unable to maintain their independence. From the accession of Edward IV. the strength of Parliament begins to decline, and the strength of the Crown begins to revive.

Characteristics of the Mediæval English Parliament.-In order to understand the constitutional history of this period, we must try to form a clear idea of the mediæval Parliament. We must lay aside certain notions derived from the observation of Parliaments as they exist now. One or two instances will make this clear.

As the English Parliament came to consist of two houses, and as the Parliaments of other countries have been modelled upon the Parliament of England, most Parliaments at the present day consist of two houses. We are therefore apt to suppose that the houses of Parliament must necessarily be two, neither more nor less; but there might have been in England-there actually were in other mediæval countries-Parliaments of three, or even of four houses.

Again, as most legislative proposals are now introduced in the House of Commons, and the influence of the House of Lords is felt chiefly in revising them, we are apt to suppose that this division of labour was the reason why England came to have two houses of Parliament ; but the reason why two houses are useful now is different from the reason why two houses came into being. In order to understand the form taken by Parliament, we must understand the mediæval notion of Estates.

Estates of the Realm.- "Estate" in this context has nothing to do with property; it signifies an order, condition, or class of men. In every large society there are many such classes, but in the mediæval kingdoms of Western Europe certain distinctions of class were exceptionally important. During the period of disorder which followed the downfall of the Roman Empire, the principal landed proprietors had gained political predominance. 
They formed the feudal nobility which governed and fought. Under this nobility the common people lived in subjection, and busied themselves in agriculture and commerce. A third class, recruited from the other two, was the clergy. The clerical was the one great learned profession. The clergy, besides doing their clerical duty, were schoolmasters, professors, authors, artists, civil servants, lawyers, and statesmen. They formed a separate order, with a government, laws, and privileges peculiar to itself. Thus the nobles, the commons, and the clergy were, as classes, far more strongly distinguished than are the classes of modern society.

But the mass of the people was in some countries further subdivided. The lower classes were stronger in the towns where they were collected together, than in the country districts where they were scattered. Hence the towns generally contrived to gain municipal self-government. They contrived to shake off the power of the feudal nobles, and to place themselves under the direct protection of the kings. Then the citizens of these towns, the burghers, formed in some countries an Estate by themselves distinct from the country people. In this case the peasants might become a separate Estate, or they might remain so completely subject to their lords as not to be counted at all.

The Mediæval Parliament a Parliament of Estates. -Every mediæval Parliament was a Parliament of Estates. It did not represent the nation as a single body. Nor did it represent each individual equally with every other individual. It represented each of the great orders or Estates which we have tried to describe, and it represented them severally. It might, therefore, have had as many houses as there were Estates of the realm. In France the States-General consisted of three houses, one for the clergy, one for the nobles, and. one for the burghers. In Sweden the Rigsdag contained four houses, for in Sweden the peasants had gained what they did not gain in France, recognition as a separate Estate. In Scotland the three Estates formed only one House. 
But there the inferior clergy, the landowners other than tenants-in-chief, and the towns not on the king's demesne were not represented. The Scotch Parliament was really a feudal assembly of tenants-in-chief. In England the three Estates were more fully developed. If Edward I. could have fixed the constitution, there might have been three Houses of Parliament.

\section{The Mediæval Parliament a Parliament of Local} Communities.-As a rule, an Estate of the realm would be too numerous to attend Parliament in a body. Even the nobles were in most instances too many for this purpose. The clergy and the commons could attend only by their representatives. But mediæval representation was never proportioned to numbers. The mediæval principle of representation was that every corporate body should be equally represented. Thus, in the English Parliament, every county, and, with one or two exceptions, every borough, had two members, whatever might be its size, population, or riches. The House of Commons was so called, not because it represented common or vulgar people, but because it represented the communities (Latin, communa; French, commune) of the kingdom of England.

Definition of a Mediæval Parliament.-A mediæval Parliament was an assembly of the Estates of the realm. If an Estate of the realm were too numerous to appear in person, it was represented by persons chosen by the corporate bodies which made up that Estate.

Constitution of the Three Estates in England.-The constitution of the three Estates of clergy, nobles and commons in England was in many respects peculiar. It is therefore necessary to consider each Estate somewhat in detail.

I. The Estate of the Clergy.-The archbishops and bishops had been members of the Anglo-Saxon Witenagemote. After the Norman Conquest they were members of the great council, in virtue both of their spiritual dignity and of their estates held on a baronial tenure. The whole 
body of the clergy had their separate assemblies, the Convocation of the province of Canterbury and the Convocation of the province of York. When Edward I. provided for the representation of the commons, he also provided for the representation of the inferior clergy. The inferior clergy of each cathedral and of each diocese were to choose proctors to represent them in Parliament. Had the inferior clergy availed themselves of this opportunity, their representatives, together with the prelates and abbots, might have formed a third house. This was what happened in France. But in England the clergy preferred to tax themselves and to legislate for the Church in Convocation. Thus their representatives dropped out of Parliament. The prelates and abbots, who held their estates by baronial tenure and were specially summoned like other barons, continued to sit in Parliament, but did not form a separate house.

II. The Estate of the Lords Temporal.-With reference to this Estate we must bear in mind one fact most momentous for English history. England has never had a nobility like the nobility of France or Germany, forming what is sometimes called a caste. In France or Germany it was extremely difficult for any man not born a noble to become noble, whilst all the offspring of a noble were noble too. Every member of the nobility enjoyed a number of privileges not enjoyed by any who were not noble. In England it was much less difficult for a commoner to attain to nobility. All the children of an English noble, except the one who actually succeeded him, were commoners. The only privileged persons in England were the holders of peerages. So in England there never was any large and exclusive class of nobles. Good birth was highly respected, but good birth alone gave no legal or constitutional privilege. The basis of the peerage was not birth, but tenure or summons.

According to the strict feudal theory, all the tenantsin-chief should have been summoned to Parliament. The Great Charter expressly promised that this should be done. 
But this the kings of England hardly ever did. They usually summoned to council only the greatest of their tenants-in-chief. The lesser tenants-in-chief were too many to act as a council. They disliked the trouble of a long journey to court. They felt themselves humbled in the presence of the great barons. So the strict feudal theory was never carried out. The fact that a man held land directly from the king did not ensure him a right to be personally consulted by the king.

Thus the Estate of the nobles in England came to consist only of those whom the king expressly summoned to Parliament; or, as it is expressed in legal language, from the time of Edward I. it was barony by writ, not barony by tenure, which gave the right of sitting in the House of Lords. The House of Lords, therefore, is not a truly feudal assembly. The House of Lords could have taken its actual shape only when feudal ideas were beginning to become obscured.

III. The Estate of the Commons.-In England this Estate contained more varied elements than in any other country. It did not consist merely of the burghers of the towns, or even of the burghers jointly with the peasants. It included many other persons who elsewhere would have been regarded as nobles, and would have swelled the second Estate.

Reasons why this was so.-One reason of this peculiarity was the fact that only such persons as the king specially summoned had the right to sit in the House of Lords. The lesser tenants-in-chief and all the men of good family who did not receive this summons went to swell the third Estate. Another reason was the strength of English local institutions. The commons, we have said, were the "communities," the organised bodies in which the people were marshalled. In most parts of Western Europe the only large communities of this kind were the cities. But in England the shires had kept their local self-government. In the shire court all the free owners of land had been trained to act together. In the 
county court they had all met to receive the king's judges upon circuit. It was natural that they should all meet to choose the representatives who were to speak with the king. The same reason explains why the people of the towns and the people of the country did not form separate Estates of the realm. Although a few great towns had risen to the rank of counties, most of the towns remained part of the counties in which they were situated. Their citizens came to the county court, and there met and cooperated with the country people. To this happy union of many varied elements, of the personal pride and political experience of the gentry, with the stout hearts of the yeomen and the active intelligence of the burghers, the third Estate in England owed its stubborn life and evergrowing energy.

Classes not included in the Estate of the Commons. -From the third Estate we must, however, exclude a considerable part of the population.

(I.) The villeins, a large although diminishing class, had no share in the administration of the county or in parliamentary representation.

(2.) The landless freemen, whether tenant farmers or simple labourers, were also disqualified.

(3.) Those inhabitants of a town who had no share in its local administration had no share in electing its representatives in Parliament.

We cannot now determine the numbers contained in any of these classes in the fourteenth century. The proportion of persons of the third class would differ in every town according to its particular constitution.

Distribution of Representatives.-Every shire had two members; London had four members, and every other city or borough usually had two. There were only thirty-seven counties in England. Cheshire and Durham were still separate jurisdictions (counties palatine). Wales was regarded as a dependency, not as a part of England, and was not yet completely divided into shires. It was represented only in two Parliaments before the time of 
Henry VIII. The number of boroughs represented was different at different times. The greatest number represented in any mediæval Parliament was 164; the usual number was about 100. Thus the House of Commons would usually contain 74 knights of the shires, and about 200 members for cities and boroughs. Although the landowners were the most powerful class in the kingdom, and although the great mass of the people lived in the country, the representatives of the shires were far fewer than the representatives of the towns. This shows how little mediæval representation. took account of numbers. We find, however, that the knights of the shires were by far the most influential members of the House of Commons, and that the borough members commonly followed their policy.

Who were Qualified to Elect Members of Parliament. - The general constitutional principle was that the persons entitled to take part in the business of the county court were entitled to take part in the election of members to serve in Parliament. This principle had been accepted for more than a century before it was embodied in a statute. An Act of Henry IV., passed in 1406, provided that the election of members should take place in the full county court. But an Act of Henry VI., passed in 1430, confined the county franchise to persons having a freehold worth at least 40 . a year (equivalent to $£ 30$ at the present day). Some writers have thought that this restriction had a great effect upon the character of Parliament, but of this there is scarcely any evidence. No general statute regulating the franchise in boroughs was passed until the Reform Act of I832.

Who were Qualified to be Elected as Members of Parliament.-In the counties men of birth and estate would be most likely to be elected. A statute of Henry VI. required that the persons elected by the counties should be belted knights. Hence the term "knight of the shire," to express a county member. But there is evidence that both before and after the passing of this 
Act many simple esquires were elected by the counties. No general statute regulating the qualification of borough members was passed until I III.

Freedom of Election.-The freedom of election was often infringed. Sometimes a great lord interfered to secure the return of his nominees. Sometimes the sheriff interfered to secure the return of persons subservient to the king. Sometimes a disorderly mob burst in and claimed to elect whom it pleased. In I 377 John of Gaunt, who then controlled the government, procured, apparently by undue influence, the return of an obsequious House of Commons to undo the work of the Good Parliament. The Act of I406, already mentioned, was passed on the complaint of the House of Commons that undue influence was used at elections.

The Right of Representation Little Valued.-We must not think that in the fourteenth or fifteenth century Englishmen laid so much stress upon being represented in Parliament as they do now. The king had originally invited the commons to send representatives, because this was the easiest way of raising money. But the commons were not fond of making money grants. The boroughs were taxed at a higher rate than the country districts. Accordingly we find several cases in which a borough petitioned the king that it might no longer send representatives to Parliament. Another reason why representation was sometimes felt onerous was that all members of Parliament received wages.

A Seat in Parliament Little Valued.-Even the allurement of wages did not always make a seat in Parliament attractive. At this time men of good standing took much more interest in local, and much less interest in national affairs than they did afterwards. They were often loath to undertake the irksome business of satisfying the king's demands without raising the anger of their constituents. These discomforts were not yet outweighed by the power and the chance of celebrity which members of Parliament afterwards enjoyed. We are told of one occasion on which 
the gentlemen chosen by Oxfordshire fled the county. The sheriff raised the hue and cry and pursued them like thieves or murderers. One escaped, but the other was taken and bound over to appear at Westminster when the Parliament should assemble.

Duration of Parliaments.-A mediæval Parliament lasted only for one session. The sessions were usually short. There is one instance of a session which lasted for nearly half a year, but usually a session lasted little more than a month. It was usual to call a Parliament every year, and this custom was turned into law by statutes of 1330 and I36r. But we know of one year in which four Parliaments were held.

Growth of the Power of Parliament.-We can now form a notion of the mediæval English Parliament. We have next to trace the principal steps by which it acquired power in the State. We have to consider the functions which it acquired with reference to-(I) Taxation; (2) Legislation; (3) Responsibility of the Ministers of the Crown.

(I.) Control of Taxation by Parliament.-The king's want of money had been a principal cause of the rise of Parliament, and Parliament may be said to have bought its powers by supplying the necessities of the king. It is true that the parliamentary control of taxation meant in the fourteenth century something very different from what it means now. At the present day the national expenditure is enormous, and is largely defrayed out of revenues voted year by year. In the fourteenth century the national expenditure was so small, that, if a king were frugal and refrained from making war, he could meet it out of his hereditary and feudal revenue, which was very. considerable. Hence the demand so often made by the reformers of that time, that "the king should live of his own," that is, should not demand any direct taxes at all. But our kings loved courtly splendour and military renown. They were therefore obliged to ask frequently for help from their Parliaments. In this way the control of Parliament over taxation, and indirectly over the whole. 
business of government, was always becoming more effectual.

Even under Edward II. there were many complaints of taxation imposed without the national consent, and such taxation was more than once declared to be unlawful. But under Edward III. we entered upon the Hundred Years' War with France, which kept the treasury always empty. In the year I 340 Edward had to demand an unusually large supply, and therefore had to consent to a memorable statute, which enacted that no charge or aid should henceforth be made but by the common consent of the prelates, earls, barons, and other great men and the commons of the realm of England in Parliament assembled. By this statute the king lost the power of imposing a tallage or special tax upon the inhabitants of his royal demesne, a power which had not been expressly taken away by the Confirmation of the Charters. Edward III., like Edward I., tried more than once to extort sums of money from the wool merchants. But in I 362 and I37 I he had to accept statutes providing that no tax should be levied upon wool without the consent of Parliament. Tunnage, a duty of so much per tun of wine, and Poundage, a duty of so much on the pound's worth of general merchandise, were regularly granted by Parliament from the year 1373 onwards.

Richard II. was equally in want of money, and more despotic in temper. In 1398, Richard took a step towards financial independence by obtaining from Parliament a subsidy on wool and leather for the term of his life; but he was deposed in the following year. The Lancastrian kings showed themselves anxious to conciliate Parliament in the matter of taxation. That no new tax could be imposed without the consent of Parliament had now become an established rule. Only after the accession of the House of York was the force of that rule impaired. Edward IV. began in I473 the practice of extorting Benevolences from the rich. These Benevolences were in name free gifts, but in reality 
forcible exactions. They are the first of the new devices for raising a revenue without the consent of Parliament, which helped to bring about the great constitutional struggle of the seventeenth century.

Whilst the Parliament was gaining control over taxation, the House of Commons was gaining the principal share in that control. This was the natural consequence of the fact that the House of Commons represented, not indeed the richest men, but the greatest sum total of riches. In the year 1407, Henry IV. formally laid down the rule that neither House should make a report to the king on any grant of money until both Houses had agreed among themselves, and that they should then make their report through the Speaker of the House of Commons. This rule seems to be the foundation of the rule now in force, that the House of Lords cannot modify a money Bill sent up from the House of Commons, but must accept or reject it as it stands.

(2.) The Share of Parliament in Legislation.-In the mediæval period of our history there was comparatively little legislation. The old customary law sufficed for most of the wants of a society which was changing very slowly and quietly. If you look at an edition of the Statutes at Large in a public library, you will see that all the statutes passed between the issue of the Great Charter and the Reformation do not fill as many volumes as the statutes passed in ten years of the present reign. But it was acknowledged at an early period that a valid law could not be made except in Parliament. In the year 1310 a council of the great men of the realm had appointed certain prelates and barons to draw up rules for amending the abuses which had sprung up under the weak hand of Edward II. Those prelates and barons, known as the Lords Ordainers, published certain ordinances which received the sanction of Parliament, But in the year I322, when Edward had crushed his enemies and regained his power, he called a Parliament to annul the ordinances. They were annulled expressly on the ground 
that they had not been originally made in Parliament. In future all legislation was to "be treated, accorded, and established in Parliaments by our lord the king, and by the consent of the prelates, earls, and barons, and the commonalty of the realm, according as hath been heretofore accustomed." Whatever might be Edward's motive in obtaining the declaration, it is significant of the growing strength of Parliament.

The form of legislation in the fourteenth century was different from its form in later times. Already the greater number of legislative proposals took their rise in the House of Commons. But these proposals took the form of petitions, not of Bills. As the king asked the Commons for money, so they petitioned him for the redress of grievances. A statute was usually said to be made by the king on the petition of the Commons, and with the advice and consent of the prelates and barons. This difference in form corresponded to a difference in substance. So long as a legislative proposal was couched in the form of a petition, the king might modify it whilst accepting it. When a legislative proposal was couched in the form of a Bill, the king could only accept or reject it as it stood. He thus lost a great part of his legislative power. For when he could no longer modify a proposal which he disliked, he might have to accept it as a whole for fear of the consequences if he rejected it as a whole.

In the year I4OI the Commons petitioned Henry IV. that the king's answer to their requests might be declared before the grant of money was made. But Henry, much as he desired to conciliate his Parliament, refused this request as being without precedent. In I4I4 the Commons petitioned Henry V. that the laws made upon their petitions should follow exactly the terms of those petitions, without either addition or diminution. The king granted their request. After this concession the replacing of the petition by the bill was merely a formal precaution. In the course of the fifteenth century legislation by Bill became the rule, and the sovereign lost for ever his power 
of amending legislative proposals, although he might still reject them altogether.

(3.) The Responsibility of Ministers to Parliament.At the present day the Ministers of the Crown are really appointed and dismissed by Parliament; but before the Revolution of 1688 , the Ministers of the Crown were really appointed and dismissed by the king. In the Middle Ages the king was still the real head of the executive government. The Parliament made several attempts to lessen his power in this respect, as by choosing his Ministers for him; but these attempts failed, because in those days the Parliament was neither sufficiently united nor sufficiently well informed to supervise the executive. It was the more necessary, therefore, that, if the king's Ministers were guilty of gross misconduct, Parliament should have the power of bringing them to justice. This power was first exercised in the year 1376. The later years of Edward III. had been disastrous. The French war dragged on without any result beyond producing much misery. The king was growing decrepit; his son, John of Gaunt, controlled the administration, and John's creatures were made accountable for the prevailing misgovernment. The discontent of the people was freely expressed in the Good Parliament. Amongst other culprits, Lord Latimer, the king's chamberlain, was charged by the Commons with corruption and embezzlement of public money, and was sentenced by the Lords to loss of office and to imprisonment. In the reign of Richard II. the same procedure was used to destroy, first, the king's favourites, and then the king's enemies. In 1450 the Duke of Suffolk, the Minister of Henry VI., and the favourite of his queen, was impeached by the Commons before the Lords.

Position of the Crown in this Period.-In this period the king of England was no longer absolute; he was a constitutional king. In this change he had lost much of his former power; but we must not suppose that the power of any of the later Plantagenet kings was at all as 
limited as the power of a modern king of England. The king continued to be the real as well as the nominal head of the government. He did not delegate his work to a Prime Minister. As king in Parliament, he took a personal share in making law; as king in council, he controlled the administration. The Ministers of State were appointed by him and dismissed by him; they owed fidelity exclusively to him, not as they do now, to one another also. The king was still in reality, not in name only, commander-in-chief. The king's hereditary and feudal revenue defrayed most of the ordinary charges of government. It was only when he needed an additional supply that he had to allow the interference of Parliament in choosing public servants or in managing public affairs. Even if the Parliament were inclined to be masterful, it sat only for a short time, and had hardly any opportunity of understanding the details of administration., The king, in one word, was still the government, although the government was from time to time counselled, censured, or resisted by the three Estates of the realm.

Position of the Church in this Period.-The power of the Church was still great, but it was beginning to decline. For this decline there were many reasons. First, the clergy were no longer the leaders of the people. Down to the time of John the clergy had led the nation in the endeavour after freedom and good government. From the time of John to the time of Edward I. the clergy had been more and more hampered by their dependence on Rome, and had gradually made way for the barons as leaders of the people. From the time of Edward I. the Commons had gradually been asserting their independence. Thus the clergy had lost much of their political pre-eminence. By degrees the clergy were also losing their intellectual pre-eminence. The great literary works produced by laymen like Chaucer show that in the fourteenth century the clergy were no longer the only learned and cultivated class. As they lost their intellectual pre-eminence, they lost much of their authority as religious teachers. The 
spread of Lollardy is the first sign of a wide-spread disposition to question the teaching of the Church. Attacks upon the doctrine of the Church awoke the spirit of persecution in the clergy and narrowed their sympathies. Thus there gradually opened a breach between the clergy and the most intelligent of the laity.

There was also a decline in the religious zeal of the clergy themselves. Enthusiasm is necessarily short-lived. The impulse given by the Cistercians in the twelfth century and by the Friars in the thirteenth century was now spent. The long enjoyment of immense wealth, of power, of honour, and of dignity, had relaxed the energy of the churchmen and left them timid, indolent, and self-indulgent. Several of the Popes who dwelt at Avignon in the fourteenth century were weak and dissolute men, who did nothing for the discipline of the Church. The growing disposition to question the doctrines of the Church made itself felt even among the clergy. The clergy $y_{3}$ in fact, believed less and less in themselves; therefore other men believed less and less in the clergy.

Whilst the clergy were losing power there were causes which embittered the laity more and more against them. One of these causes was their excessive wealth. The Church being immortal, was always acquiring riches, but never lost any. Edward I. had tried to prevent any further acquisition of land by the Church. Certain knights of the shires proposed, in I4O4, that the king should take one year's revenue of the Church to defray his expenses. In I 410 the Commons are said to have proposed the confiscation of all the estates of the bishops and monasteries. In I4I 4 the Parliament actually granted to Henry V. all the estates of the "alien priories," that is, priories belonging to foreign monasteries.

Another grievance of the laity was the tyranny of the "spiritual courts," that is, Church courts which undertook to repress forms of immorality not punishable under the criminal law. These courts were often corrupt, and their action necessarily produced much spying, malicious 
prosecution, and wilful perjury. Yet they survived the Reformation, and were rendered harmless only in the time of Charles I.

But the grievance most keenly felt ever since John's surrender to the Pope was the intolerable interference of Rome. At the Parliament of Lincoln, held in I30I, the barons declared that the king of England was accountable to no earthly jurisdiction whatsoever, In I366 the Papal lordship and the tribute payable to the Pope were formally renounced. Successive Parliaments contended against the practice of taking suits to Rome and of obtaining authority from Rome. Statutes punishing this practice with forfeiture of goods and outlawry were passed in I353, I365, and 1393, and are known as the Statutes of Præmunire (from Latin, premunire, signifying to admonish). The Parliament also passed, in I $35 \mathrm{I}, \mathrm{I} 362$, and 1390, the Statutes of Provisors to prevent the court of Rome from bestowing ecclesiastical preferment in England.

Position of the Nobles in this Period.-The character of the baronage was much changed under the later Plantagenets. Under Edward II. the barons are, as they had been under Henry III., leaders of the general opposition to a weak and misguided king. Edward III. was better able to control them. He gained their regard as a magnificent king and a renowned warrior. He found an outlet for their energy in the conquest of France. He tried to gather as many as possible of the great fiefs into the hands of his own children. But Edward's policy did not secure the peaceable succession of his descendants. The barons continued to be restless and powerful. The baronial families were fewer and their possessions were greater than ever. They could not demand the service of their vassals for private warfare, but they had the means and the will to maintain numerous households of men, to whom they gave their livery, and who were ready to take up arms at their bidding. Under the feeble government of Henry VI. these turbulent lords; with their hosts of retainers, became ungovernable. The evil was only 
cured by the gradual dying out of some of the ancient families and the destruction of others in the Wars of the Roses.

So long as the old baronial houses survived, however, they never quite lost their place as leaders of the people. In every crisis of misgovernment some at least of the lords took part with the commons. The commons, although gradually gaining experience and power, could not yet have resisted the court party by their own unaided strength. When the barons had lost their independence, it was not the commons, but the king who immediately gained in power.

Position of the Commons in this Period.-Slowly but steadily the third Estate advanced under the later Plantagenets. Under the Lancastrian kings its representatives took a part in national affairs hardly inferior to that taken by the Lords. Its numbers and its wealth were little affected by the Wars of the Roses. Whilst the nobles and their retainers were fighting, the merchant and the yeoman continued their peaceful and profitable industry. The kings of the House of York studied to gain the goodwill of the middle class. For, although this class was not yet powerful enough to govern, no government could now be secure without its support; and this support it was willing to afford any ruler, however arbitrary and severe, who manifested a stern resolution to put down anarchy in every shape. The constitutional monarchy of the House of Lancaster had failed to maintain order, and the commons had become indifferent to political freedom unaccompanied with personal security.

The Peasant Revolt and the Extinction of Villeinage.-It is probable that from the twelfth century onwards the number of villeins had been constantly diminishing, and the number of freemen constantly increasing. The villein had several ways of releasing himself from bondage-he might buy his freedom; he might become free by residing for a year and a day in a chartered town, if within that time his lord did not reclaim him; he might 
take holy orders (although laws had been passed to hinder his doing so); finally, the Church regarded the bestowal of freedom upon the villein as an act eminently pleasing to God, and thus many lords were persuaded to emancipate their villeins for the benefit of their souls. Even when no formal emancipation took place, the vexatious personal service required of the villein was frequently commuted for fixed money payments. But when the Black Death of I 349 carried off a great part of the population, this happy transformation of serfs into free men was violently arrested. As labour was scarce, wages rose. The lords tried to retrace their steps, and once more to exact from the villein not money, but personal service. Statutes were passed to keep down the wages of labour. These and other grievances provoked the peasants' rebellion of $138 \mathrm{I}$. That rebellion failed of its immediate object. It showed, however, the difficulty and danger of trying to revive villeinage. The decay of villeinage now went on more rapidly than ever. By the end of the Wars of the Roses villeinage had all but disappeared; almost every Englishman was now a freeman.

Growing Inequality of Conditions. - Every great social improvement gives rise to new social difficulties. Now that all Englishmen were free, a much greater proportion of freemen were without property. The villeins had been too valuable to their lords to be evicted, but the tenant farmers and labourers who took their place might be cleared off the land whenever it could be more profitably used in some new way which afforded less employment. At this time the growing demand for English wool led capitalists to acquire large tracts of land, and to use them as sheep-walks, on which hardly any labour was required. Great distress was thus caused in many parts of England. Meantime the wool-farmers and the merchants and manufacturers of the towns acquired wealth hitherto unknown in the English middle class. Thus the contrast between wealth and poverty became more marked in the fifteenth than in preceding centuries. Yet 
there was also a wide diffusion of rude plenty. The bulk of the people were far more prosperous in England than in any of the neighbouring communities. Some historians, looking chiefly to the evils of which we have spoken, represent the fifteenth century as a time of national wretchedness; others, looking chiefly to the spread of personal freedom and the progress of industry, describe it as a golden age. 


\section{CHAPTER VIII.}

THE TUDORS, 1485-1603.

Introduction.-The chief characteristic of the later Plantagenet period had been the growth of the power of Parliament; but this growth had been arrested at the accession of Edward IV. A new political tendency then set in, and continued to be felt under the Tudor dynasty. Once more the power of the Crown began to grow.

At the end of the Wars of the Roses the balance of the constitution had been destroyed. The barons had been almost extirpated. The clergy had lost their hold upon the religious feeling of the nation, and were hated for their wealth and pride. Formerly they had mediated between the king and his people. Now they clung to the king for protection. The middle class, who elected the House of Commons, had suffered little in the civil war, and enjoyed considerable prosperity, but they were not strong enough to dictate the national policy. They desired, above all things, the restoration of public order. They were therefore disposed rather to magnify than to question the authority of the Crown. Thus the whole nation was ready for the sway of the unscrupulous and despotic, but brave and sagacious, sovereigns of the House of Tudor.

Henry VII. united the claims of the House of York and the House of Lancaster. He baffled by his dexterity every attempt at revolution. He brought the nobles under control, gained the goodwill of the middle class, and accumulated the greatest treasure ever yet possessed by an English king. Henry VIII., succeeding to the fruit 
of his father's labours, and ably served by Wolsey, found himself more powerful than any of his predecessors since Edward I. He broke with Rome, and thus involved England in such difficulties as made personal government necessary. From the year in which the English clergy renounced the authority of the Pope to the year in which the Spanish Armada was defeated (1532-88), England was exposed to destruction from within and from without, to civil war and to foreign invasion. Such perils could be averted only by the assertion of almost absolute royal authority.

Henry VIII. attempted to take a middle course in religion. Edward VI. and the Protector Somerset took part with the Protestants, Mary with the Catholics. Elizabeth resumed her father's task of controlling all parties. With the assistance of wise councillors she succeeded in establishing Protestantism as the national religion and in defeating all attacks upon England; but her very success in this great work prepared the way for fresh conflicts within the Reformed Church of England. As the Crown took part with the bishops, the Puritans became a political opposition. After the death of Elizabeth and the extinction of the Tudor line, this opposition defeated the Crown and placed monarchy under limitations more strict than any yet known.

We must not exaggerate the extent of the revival of royal power in the Tudor period. Many writers have expressed themselves as if the Tudors were really absolute monarchs. If they meant that the Tudors could disregard the feelings of the nation, they were mistaken. The Tudors had no standing army. They ruled over a warlike people. If they were able to do many harsh and unlawful things, this was because their subjects suffered them to do so. The Tudors were singularly attentive to the movement of public opinion, and seldom persevered in any line of policy which it distinctly condemned. Again, if these writers meant that the Tudors were formally absolute, this is still further from the truth. 
None of the old institutions which protected political and personal freedom was abolished. The most tyrannical acts of the Tudors were done in legal form. The tradition of constitutional monarchy was never broken.

Relations of the Tudors with their Parliaments.The revival of the royal power in the Tudor period necessarily implied some diminution in the power of Parliament, but the Tudor sovereigns sought rather to make Parliament do their work than to deprive Parliament of any of its constitutional functions.

The House of Lords had lost its strength and independence in the Wars of the Roses. So many of the barons had perished in the field or on the scaffold, that the first Parliament of Henry VII. contained only about one half the number of lay lords which had met in the fullest Parliament of Henry VI. Even this remnant of the old nobility was reduced by executions and forfeitures in the reigns of Henry VII. and Henry VIH. The spiritual lords were also ready to subserve the Crown, because they no longer felt secure of the support of the nation. Henry completed the subjugation of the Upper House by his dissolution of the monasteries. The dissolution involved the disappearance from Parliament of the great abbots. It thus reduced the number of the spiritual peers by one half, and gave the lay peers that majority which they have never since lost. The dissolution of the monasteries also placed at the king's disposal a vast landed estate, with which he endowed a new nobility, submissive to him, because they had as yet no root in the country, and favourable to the Reformation, because a reconciliation with Rome might imperil their estates. Even the zealous Queen Mary, when she brought her kingdom once more into communion with Rome, had to confirm the grant of the abbey lands to their new possessors. Usually we find the House of Lords even more subservient than the House of Commons.

The causes which strengthened the loyalty of the middle class in this period rendered the House of Com- 
mons favourable to the pretensions of the Crown. But the Tudors took means to confirm their hold on the House of Commons. It had always been the prerogative of the Crown to determine what boroughs should send representatives to Parliament. In the reigns of Edward VI., Mary, and Elizabeth, no less than sixty new boroughs were created. Some of these new boroughs had a fair claim to representation, but most of them were insignificant places, chosen because the Crown could secure the return of persons subservient to its policy. The great anomalies of representation dealt with in the Reform Act of I 832, although partly due to the gradual shifting of population, were partly due to the unscrupulous policy of the Tudor sovereigns.

On the other hand, Henry VIII. completed the formation of the Welsh counties, including Monmouth, and gave parliamentary representation to them and to Cheshire. The House of Commons ventured occasionally to resist even Henry VIII. In the later years of Elizabeth they began to display the temper which proved so fatal to the Stuarts.

Control of Parliament over Taxation in the Tudor Period.-That the Parliament alone had the right to impose direct taxation was not openly disputed by the Tudors or their Ministers, but the dependence on Parliament involved in this principle they tried to evade by various expedients. Henry VII. raised money by the rigorous enforcement of the rights of the Crown, however antiquated, by levying large fines upon law-breakers, and by other means not strictly illegal. By avoiding war and practising severe economy, he was able not only to meet expenses, but also to lay up a great treasure.

Henry VIII. was wasteful, and in a few years spent all that his father had saved. In I 523 Wolsey demanded of the House of Commons the enormous sum of $£ 800,000$. After much resistance he obtained a much smaller sum, to be paid in four years. But he compelled the taxpayers to pay the whole at once. In I 522 and I 525 Wolsey took 
a bolder step. He appointed commissioners to swear every man as to the value of his possessions, and levy a rateable part of the value. But on the second occasion the people broke into open rebellion. The king had to withdraw his demands, and to grant a pardon to all who had resisted his officers.

More success attended the levying of benevolences, or pretended free gifts from rich men. This practice had been introduced by Edward IV., but was declared illegal by a statute of Richard III. The Tudors treated this statute as void, on the pretext that Richard was not a lawful king, but a usurper. Henry VII. had occasionally demanded benevolences; Henry VIII. demanded them frequently. Those who refused were summoned before the Privy Council and sharply reprimanded. If they remained obstinate, they were sent to prison or to serve as common soldiers.

Henry VIII. also had recourse to forced loans. What made the lender's case more grievous was that he twice obtained an Act of Parliament relieving him from his debts. The second Act went so far as to provide that if the king had paid any of his creditors, they should repay the king. Elizabeth occasionally took a forced loan, but she repaid the principal, and gave knighthood or civil speeches by way of interest.

The consent of Parliament was not so clearly requisite for the imposition of duties upon imported merchandise as for direct taxation. It is true that the spirit, if not the letter, of the memorable statutes which took away the right of arbitrary taxation from the Crown included indirect as well as direct taxes; it is true that certain indirect taxes, especially upon wool, had been either regulated or abolished by statute; it is also true that during the fourteenth and fifteenth centuries Parliament had established the precedent of granting by an Act all the duties usually levied upon merchandise, the customs payable upon staple comnodities (wool, sheepskins, leather, and tin) when exported, the tunnage or duty of so 
much per tun upon wine imported, and the poundage or duty of so much per cent. on the value of all other imported commodities; but nowhere could there be found any statute in plain words forbidding the king to levy any duty whatsoever without the consent of Parliament. The statutes limiting the king's power to tax were construed even in later times as narrowly as possible. He was held to retain every prerogative which was not taken away in words so stringent as to defeat all evasion. Moreover, the lawyers held, and even Parliament did not dispute, that the king had peculiar prerogatives with regard to the foreign commerce of the kingdom. The ports were his, to open or to close; then why not demand a consideration for opening them to certain commodities? Acting on this view, Mary levied an imposition, as it was called, upon foreign cloth, and Elizabeth levied an imposition upon sweet wines; but prudence withheld the Tudors from multiplying such impositions.

Forfeitures. - In this period the Crown derived a great revenue from forfeitures. Henry VII. had the gleanings of the civil war. Henry VIII. had the spoils of the monasteries and of the victims of the law of treason. Edward VI. took some at least of the endowments of the guilds. Much of the wealth so easily gained was wasted. Yet the Tudors, by means of this and the other resources which we have mentioned, were enabled to govern without calling Parliaments so frequently as custom and law required. Henry VII. called no Parliament in the last five years of his reign. Henry VIII. governed without a Parliament from I 523 to I 529. Even Elizabeth once allowed five years to pass without calling a Parliament.

Control of Parliament over Legislation in the Tudor Period.-The principle that the king could not make law without the consent of Parliament had been too firmly established under the Plantagenets to be questioned by the Tudors; but the Tudors availed themselves to the utmost of a right claimed and exercised by their pre- 
decessors - the right of issuing ordinances. In the year I 539 Henry VIII. obtained the passing of an Act which gave to his proclamations the full force of law. The Act, however, provided that no proclamation was to overrule the common law, or to affect the rights of any subject to his personal freedom or his property. This Act was repealed soon after the accession of Edward VI. ; but the Ministers of Edward issued many proclamations to regulate Church ceremonies, the price of provisions, and other matters of public interest. One proclamation of this reign orders the justices of the peace to arrest all spreaders of false news and commit them to the galleys, there to row as slaves. A still more arbitrary proclamation, issued by Queen Mary in the last year of her reign, threatens with summary execution all persons found to have heretical or seditious books in their possession. Elizabeth issued proclamations threatening rioters and vagrants with the penalty of death. It does not appear how many persons actually suffered punishment under such proclamations, which may have been made chiefly in order to terrify. The power of making them was, however, quite inconsistent with a limited monarchy. A sovereign who could menace offending subjects with capital punishment for offences not capital by the ordinary law, and without trial in due legal form, was dangerously near to becoming absolute.

But the most important instance of this irregular legislation is to be found in the ordinances published in 1585 for the regulation of the press. By these ordinances the calling of a printer could be practised only in London and the two Universities. No printer of less than six months' standing was to continue his trade, and no man was to enter on the trade until the excessive number of printers had been reduced within such limits as the Archbishop of Canterbury and Bishop of London should think proper. Every printer was commanded to certify his presses to the Stationers' Company, and no book was to be published without the approval of the Archbishop of 
Canterbury and Bishop of London. Offences against these regulations were to be punished with imprisonment. The freedom of the press had never been acknowledged in England, but the ordinances of 1585 form the first complete code of restriction.

Responsibility of Ministers to Parliament in the Tudor Period.-It cannot be said that in the Tudor period Ministers were really responsible to any other authority than the Crown. The parliamentary prosecution of greater offenders, as of Latimer or of Suffolk under the Plantagenets, or of Bacon and Strafford under the Stuarts, was under the Tudors practically unknown; but the responsibility to the Crown was more stringent than ever. The mediæval kings of England had, rarely carried the punishment of a fallen Minister beyond the loss of office and of wealth; but the anger, at least of Henry VIII., was deadly. Nor was it only his anger that was formidable; he would abandon the most faithful servant as soon as that servant had become unpopular. He would seek popularity for himself by prompting the Parliament to punish acts done in the service and for the advantage of the Crown. Thus in the beginning of his reign he allowed Empson and Dudley, the instruments of his father's exactions, to be attainted on an absurd charge of treason. Thus he incited the prosecution of Wolsey, who had laboured so zealously to increase the influence of the king both at home and abroad. Thus, having used Cromwell to enforce his ecclesiastical supremacy and to dissolve the monasteries, he sacrificed him to the vengeance of the Catholic party. By pursuing this policy he kept power in his own hands, and left others to bear the odium of its abuse. All the great prosecutions of his reign were really set on foot by him, and the Parliament presumed to destroy only those whom he had marked for destruction. Under Edward VI. the Protector suffered death, at the hands not of the Parliament, but of his rivals. Elizabeth chose her Ministers so prudently that they never became objects of general hatred; thus she was 
never obliged to sacrifice them to public opinion. She never incited the Parliament to destroy a worn-out and unpopular statesman, but she never allowed her Ministers to forget that they were absolutely responsible to her.

The Executive Government in the Tudor Period.It has been shown to what extent the Tudors succeeded in freeing themselves from the restraints imposed of old by Parliament upon the kings of England. It remains to trace the causes which made the executive authority so flexible and so powerful in their hands. Under the king the Privy Council was the chief executive authority. The Privy Council of the Tudors can be traced back to the councils of our earlier Plantagenet kings, but it differed from them in some most important respects.

From the time of the Norman Conquest our kings had carried on the government with the help of a permanent council. We have seen that this council consisted of the great officers of state and of the royal household, together with any other persons in whom the king might repose special confidence. It was competent to transact every kind of business, although it was occasionally merged in the larger council of tenants-in-chief, or at least of barons, for the purpose of making laws or levying taxes. With the progress of civilisation new institutions had been developed to take over particular portions of the work of the old Norman Curia Regis. In the thirteenth century the courts of common law, and in the fourteenth century the Court of Chancery, had become quite distinct from the council, and discharged all the ordinary judicial business.

In the course of the same period the English Parliament had taken shape, and had acquired all the powers of legislation and taxation formerly exercised by the great councils above mentioned. When these changes had been completed, the ancient Curia Regis may be said to have disappeared. But the king was still the head of the executive government, and still needed advice and assist- 
ance. Thus in the fifteenth century we stili.find royal council consisting of great officers of state and certain barons and prelates, which fulfils many of the functions of a modern Ministry. We still find this council merged from time to time in a general assembly of the baronage; but such an assembly is now an extraordinary expedient to meet a difficult crisis. The council is the normal governing authority. It is so powerful that the Parliament endeavours to control it in various ways, by nominating members, by compelling them to take an oath, by granting them wages, and by regulating their procedure.

The name of the Privy Council first occurs in the records of the fifteenth century. But the Privy Council of the Lancastrian kings was a very different body from the Privy Council of the Tudors. Not only was it influenced by Parliament in the ways already mentioned, but it was largely composed of lords and bishops too powerful to be mere instruments of the king's will. Thus it often had an independent will, and acted as a check on the royal prerogative. After the Wars of the Roses its independence was gone. Parliament ceased to interfere with the council, where the king's influence was now unquestioned. Its members were no longer powerful enough to take a course of their own. After the dissolution of the monasteries it contained few ecclesiastics. It contained several lay lords, but they no longer enjoyed the independent authority of the barons of the Middle Ages. It contained the Chancellor and Treasurer, but even they were less influential than the Secretary. The Secretary had formerly been but a superior clerk; he was now the most trusted and powerful of the Ministers. He was usually a commoner, a man of talent and ambition, who hoped to make his fortune, and could make it only by the favour of the sovereign. Cromwell, who uprooted the power of Rome, and Cecil, who overcame the power of Spain, both held the office of Secretary.

The sovereign did not always preside in the Privy Council, but he came to the meetings when important 
business wàs to be transacted. In the council he was absolute. The privy councillors might belong to the most hostile parties; they might be at deadly personal feud; but they were all obedient instruments of the monarch. The Privy Council transacted all the business which is now transacted in the Cabinet. It settled what Bills should be presented to either House, what grants of money should be demanded, what policy should be followed in the general business of government. It kept close watch on all the subordinate authorities in the State. It issued instructions to ambassadors and generals. It also acted as a court of justice; but the judicial function will more conveniently be considered. hereafter.

The Privy Council as a Court of Justice.-At all times it has been a principle of the English Constitution that the king is the fountain of justice. From the king the various courts drew all their authority. If there were any kind of wrong-doing for which no redress was to be had in existing courts, the king was expected to provide a remedy. Thus, when the courts of common law had so fettered themselves with technical rules that they became unable to redress certain wrongs, the parties aggrieved made application to the Chancellor, and this gave rise to the Court of Chancery. There was always a reserve of judicial power in the Crown. Even before the accession of the Tudors this power had sometimes been wielded through the council; but under the Tudors the council became the most powerful court of justice in the kingdom.

Why the Privy Council was so convenient as a Court of Justice.- The first advantage which the council had over all other courts was an advantage in power. The council, as the government, could use all the strength of the kingdom to enforce the decision of the council as a court of justice. Thus it was able to coerce offenders whom ordinary courts could not control; for, although the king's judges had long administered justice through- 
out England, there still were noblemen and gentlemen accustomed to take the law into their own hand, feared by plaintiffs, by witnesses, and by jurymen, and not likely to submit to an unfavourable verdict, even if such were by any chance given against them. Those sturdy lawbreakers the Tudors were determined to tame, and they did tame them by summoning them before the council, where they were sentenced to fine or imprisonment.

The second advantage of the council as a court of justice was its freedom from those rules of procedure which protected an accused person. In the courts of common law no defendant could be required to criminate himself. The council would interrogate a defendant, and, if he refused to answer, keep him in prison. In the courts of common law torture as a means of procuring evidence was unknown. The council sometimes employed torture in cases where the safety of the State was supposed to be in jeopardy. In the courts of common law the unanimous verdict of a jury was necessary to a condemnation. A simple majority of the council decided a question of innocence or guilt, as well as any other question.

The third and greatest advantage of the council was its absolute subservience to the Crown. Though the judges were often subservient too, they were restrained to some extent by the tradition of their office, and by the maxims of the common law, which in their eyes was almost sacred. The councillors had few scruples of legality, and were anxious to please the master who had raised and could abase them; so that no man could escape the severity of the council if the sovereign were known to be displeased with him.

The jurisdiction of the council extended throughout the kingdom, but, for prompter repression of disorder, Henry VIII. established two subordinate councils, the Council of the North and the Council of Wales. These councils administered in their respective districts justice of the same kind which the royal council administered elsewhere. 
In this way the Tudors, without abolishing the ancient and regular courts of justice or altering their procedure, provided the most effectual means of crushing resistance to the royal will. The Privy Council, or, what was substantially the same body, the Court of Star Chamber, the Council of the North, and the Council of Wales, were unable, it is true, to pass sentence of death, and therefore incompetent to try capital crimes; but they could inflict almost every punishment less than death, fine, whipping, mutilation, or indefinite imprisonment. They commanded a force which no subject could hope to resist; they employed a procedure which might often prove fatal to the innocent, but left no chance of escape to the guilty; they were animated by a spirit of unhesitating and unscrupulous devotion to the king's will. It was largely by means of these courts of justice that the Tudor sovereigns maintained their power through all the tumult of the Reformation.

Local Administration.-Under the Tudors the local administration of England took a new form. The ancient courts of the county and the hundred had long since fallen into decay; their judicial business had been gradually absorbed by the royal courts. The manorial courts had dwindled as the manors gradually lost their feudal character, and the villeins became freemen detached from the soil, whilst freemen were cleared away to make room for sheep. Yet the progress of civilisation made an active local administration more necessary than ever. A new administrative system was therefore built up in the county and in the parish.

The County.-Under the Tudors the sheriff and the county court make way for the Lord-Lieutenant and the justices of the peace.

The sheriff had lost much of his power in the course of the thirteenth and fourteenth centuries, but he remained the king's representative and the military chief of the shire. Under Henry VIII. the Crown occasionally intrusted the control of the militia to persons specially 
commissioned for that purpose. An Act of Philip and Mary completed the change by creating the new office of Lord-Lieutenant. The Lord-Lieutenant acted as military chief of the shire, and was answerable for the militia. Thenceforward the sheriff's chief remaining duties were to receive the king's justices of assize when they entered the county, to provide for the execution of criminals, and to make the necessary preparations for parliamentary elections.

The office of justice of the peace is older than the beginning of the Tudor dynasty. Knights sworn to keep the peace in their county are mentioned as early as the year I 195. Conservators of the peace are mentioned several times in the thirteenth century. An Act of the thirty-fourth year of Edward III. provided for the regular appointment of justices of the peace to maintain order in the county, and to hear and determine felonies and trespasses. Under the Tudors the justices became the governing authority in the county. They continued to hold this position until the passing of the Local Government Act of 1888 .

The Parish.-We have seen that in most cases the parish was shaped upon the township. The self-government of the township had decayed, but the parish was still important for all purposes connected with religion. The church then far more than now was the school, the meeting-place, the centre of local interest. The parish raised a fund to repair and beautify the parish church from time to time, and appointed churchwardens to watch over its fabric along with the priest. It was natural, therefore, that in the Tudor period the parish should be chosen as the smallest area for administration. The church-rate was imposed as a regular tax upon every householder in the parish. The relief of the poor was first assigned to the parish by various Acts of Henry VIII., which enjoined the parson and churchwardens to make a collection for the poor, and to exhort the stingy members of the congregation. The great poor-law of Elizabeth (I60r) 
provided that in every parish two overseers of the poor should be appointed. They were to make a rate, and to spend what they received in relieving the impotent poor, and in providing materials and tools for the poor who were able to work. An Act of Philip and Mary had laid upon the parish the duty of keeping up the roads, and had ordered the election of a parish surveyor for that purpose. Thus at the end of the Tudor period the local administration of the parish had taken the form which it kept unchanged down to the reform of the poor-law in 1834 .

The Towns.-Most English towns had grown in wealth and population under the later Plantagenet kings. Certain seaports and manufacturing towns had risen to great prosperity. The wealth of Bristol and Norwich in the fifteenth century is attested by the number of large and stately churches then erected, which remain even to this day. But whilst the towns grew in numbers and riches, their constitution became more exclusive and narrow. The causes of this change are obscure, and have been very variously stated by learned writers. But the change itself is generally admitted. Formerly it had been easy to become a burgess. All that was necessary was to settle in a town and to pay the local dues. From the fifteenth century onwards new difficulties were put in the way of acquiring burgess rights. Such rights became a personal privilege, to be acquired only by birth, by purchase, or by a long apprenticeship. The consequence was that the body of burgesses became smaller in proportion to the whole population of the town. Even within that body the distribution of power was changed. The apathy of the poorer burgesses, who disliked the burthen of unpaid office, co-operated with the ambition of the richer burgesses, who desired a monopoly of power. The municipal government ceased to be democratic. It was transferred to a close town-council, either elected by the richer burgesses, or even renewing itself by self-election. This revolution, begun in the fifteenth century, was in progress 
throughout the reigns of the Tudors; and since the municipal and the parliamentary franchises were closely connected, this revolution had a serious effect on the composition of Parliament. Until the Reform Act of I 832 and the Municipal Corporations Act of I835, the great bulk of the inhabitants of most towns were excluded from the municipal and parliamentary franchise.

Church Government.-It was especially in their relation to the Church that the arbitrary character of the Tudors was displayed. Henry VIII. and Elizabeth controlled the Church with a severity never equalled before or afterwards. The Plantagenets had always been baffled by the Popes in the attempt to make themselves masters of the clergy. The Stuarts were all inclined either to High Church or to Catholic opinions, and therefore entertained a certain reverence for the clergy. But Henry and Elizabeth treated the archbishops, bishops, and inferior clergy as Crown officials, whom they had made, and whom they could unmake at pleasure. Open nonconformity, whether of Catholics or of Protestants, they punished severely; but they punished it rather as an offence against the law and the authority of the sovereign than as a spiritual disease fatal to the soul. Elizabeth and her Ministers often alleged that they made no inquisition into men's opinions, and did not desire to hurt liberty of conscience. They were not entitled to say so. But it is certain that Elizabeth was not a fanatic. When she persecuted, she did so chiefly from temporal motives.

Had the great mass of the English people been zealous for any particular system of doctrine, Henry and Elizabeth could not have taken this course. They must have become the champions of a creed. But the great mass of the English people did not care much about the points at issue between zealous Catholics and zealous Protestants. What they did heartily desire was to be freed from subjection to Rome, from Papal taxation, from Papal jurisdiction, and from Papal abuse of patronage. 
It was this feeling which led them to accept and support the principle of the royal supremacy over the Church. It was the national desire for independence, joined with the royal desire for authority, which elevated Henry and Elizabeth to almost Papal domination in religious matters. Both Henry and Elizabeth understood that their supremacy was conditional on their holding a balanced policy. Neither Henry nor Elizabeth, nor the English people, had grasped the idea of toleration. Possibly toleration might not have been practicable in that period of deadly conflict; but Henry and Elizabeth alike sought to discover a compromise in doctrine and in discipline which would satisfy the moderate, the timid, the indifferent-that is, the great majority of their subjects. Supported by this majority, they felt themselves strong enough to repress the few who might revolt against spiritual dictation.

Measures taken by Henry VIII. to Enforce the Royal Supremacy.-Henry VIII. compelled the clergy to pay an immense fine for their alleged offence in recognising Wolsey's claim to authority as the legate of the Pope. He procured an Act of Parliament giving him the annates or first year's income, which the holder of every Church preferment had formerly paid to Rome, and another forbidding all appeals to Rome from the ecclesiastical courts. He brought, first, the clergy in Convocation, and afterwards the Parliament, to recognise him as supreme head of the Church of England. He suppressed first the smaller and then the larger monasteries, and distributed most of their land among laymen. By these means he had uprooted the power of the Pope so thoroughly that even Mary could not restore it.

Further Reformation by Edward VI. - Reaction under Mary. - With regard to doctrine and to ceremony, Henry VIII. had not followed any definite principle. He always enforced manyof the peculiar doctrines of the Roman Catholic Church, such as the doctrine of Transubstantiation. On the other hand, he allowed part of the Church Service to be translated, and caused an English translation of the 
Bible to be placed in every parish church. Under Edward VI. a new liturgy, resembling that now in use, was compiled. The doctrine of the Church of England was set out in forty-two articles, not essentially different from the thirty-nine articles of Elizabeth. The doctrine of Transubstantiation was rejected. The obligation of confessing to a priest was denied. The celibacy of the clergy was declared to be superstitious. Altars were taken down, statues destroyed, stained windows broken, and illuminated books of devotion were torn or burnt. The havoc thus made offended many who cared little about doctrinal disputes. Others were shocked by the worldly and greedy character of some who professed themselves most zealous for the Reformation. Finally, the attempt to secure the succession of Lady Jane Grey after the death of Edward VI. displeased the main body of loyal and law-abiding Englishmen. All these circumstances enabled the zealous Catholic party, under Queen Mary, to reverse all the reforms of Edward VI. and to carry on a cruel persecution of the Protestants. A large number of Protestants were frightened into professing Catholicism, but Mary died before persecution could produce its full effect; and all her work was undone by Elizabeth.

Measures taken by Elizabeth to Complete the Reformation. - Elizabeth republished, with some alterations of detail, the liturgy and the articles of Edward VI. Her first Parliament passed two famous statutes, which established the royal supremacy and uniformity in public worship.

Act of Supremacy, 1559.-This Act (I) compelled all clergymen holding benefices and all laymen holding office under the Crown to take the oath of supremacy, whereby they renounced the spiritual as well as temporal jurisdiction of any foreign prince or prelate; (2) made it penal, and on the third offence treasonable, to maintain by writing or deliberate speaking that any foreign prince or prelate was entitled to such spiritual jurisdiction.'

Three years later the obligation to take the oath of 
supremacy was imposed on all persons who had taken a degree at either University, who practised the law, or who sat in the House of Commons.

Act of Uniformity, 1559.-This Act (I) forbade a minister of religion to use any but the established liturgy, under pain, for the first offence, of forfeiting his goods and chattels ; for the second offence, of a year's imprisonment ; and for the third offence, of imprisonment for life ; (2) imposed a fine of one shilling on any person absenting himself from church on a Sunday or holiday.

Rise of the Puritans-The Court of High Commission.-The Acts of Supremacy and Uniformity were directed in the first instance against the Roman Catholics ; but the ecclesiastical system of Elizabeth also gave offence to some zealous Protestants. During the Marian persecution many English clergymen had taken refuge with the Protestants of Switzerland and Germany. There they learned to prefer a Presbyterian form of church government, and to condemn much of the ritual which was retained by Elizabeth. These were the first Puritans. Elizabeth would make no concession to them, and so they were led to question her supremacy. The principal writer on the Puritan side, Thomas Cartwright, went so far as to lay down that the civil magistrate should subordinate himself to the clergy in the affairs of the Church.

Some of Elizabeth's Ministers favoured the Puritans. The House of Commons from I57I onwards generally took their part. English Protestantism needed all its strength to resist the attack of the Catholic Powers. For many years, therefore, the Puritans were little molested. But in I583, Whitgift, their fanatical enemy, became Archbishop of Canterbury. He found an instrument in the Court of High Commission, which the Queen had established in virtue of a power given by the Act of Supremacy. As remodelled in that year the court consisted of fortyfour persons, but its powers could be exercised by any three of them. Its lay members did little; everything was done by the bishops and ecclesiastical lawyers. 
The court had power to inquire into all offences against the Act of Supremacy and the Act of Uniformity, including all expressions of heretical opinion, and all seditious books directed against these Acts; and into all cases of adultery, incest, and other immorality. It could administer what was known as the oath ex officio, which bound the witness to answer even such questions as might tend to criminate himself. It could deprive a clergyman of his benefice, and could also punish with fine or imprisonment at discretion.

Such was the terrible court which continued for many years to harass Puritan clergymen and laymen.

Close of the Tudor Period.-At the close of the Tudor period English society had been quite transformed from its state under the latest Plantagenet kings.

The Nobles.-The new nobility, founded in great part by Henry VIII., had by this time established itself firmly in the land. It had gained fresh dignity by intermarriage with such old families as were left, and fresh wealth by intermarriage with the mercantile class, now rising into great prosperity. It was thus in a position to take a more independent course in politics. Yet this new nobility was still quite different from the nobility which had fallen in the Wars of the Roses. The progress of the art of war had destroyed for ever the martial superiority of the nobles. The new nobility was composed, not of rude warriors, but of peaceable and polished gentlemen. Wealth, birth, education, and the habit of taking part in local and national business, gave it much influence over the rest of the community, but only with the general support of the nation could it ever defy the will of the king.

The Clergy.-The power of the clergy as an independent estate had been utterly broken in this period. The invention of printing had destroyed their monopoly of learning. The Reformation had broken down the belief in their exclusive capacity as mediums of divine grace to the laity. The Reformation had taken away the greater 
part of the wealth of the Church and the majority of the seats of the spiritual peers. The Reformation had also severed the clergy from Rome, so that the clergy could not in future balance the power of the Pope against the power of the king. Thus the clergy were reduced to entire dependence on the royal authority; they looked to the sovereign, now supreme head of the Church, to defend her against the assaults of the Papacy from without and of the Puritans from within. This was the reason why, throughout the seventeenth century, the clergy of the Church of England magnified the power of the Crown in terms which their mediæval predecessors would have thought servile, or even blasphemous.

The Commons.-The commons were now incomparably more powerful than they had been at the accession of Henry VII. In spite of periods of severe distress, commerce and industry had made great progress under the Tudor sovereigns. Under Elizabeth especially the English had become the most prosperous people in Europe. The invention of printing, the multiplication of grammarschools, the development of English litcrature, had greatly improved the intelligence of the mi 'dle class. The tumult of the Reformation, the progress of maritime adventure, and the exhilarating sense of national power, had raised their courage and self-confidence. The spread of Puritan ideas in this class tended to sever them from the nobles and the clergy, whom they had formerly followed, and to render them an independent force in politics. In the conflicts of the seventeenth centur: it is the middle class, led by the lawyers and country gentlemen, which plays the grand and decisive part. 


\section{CHAPTER IX.}

FAMES I., CHARLES I., AND THE COMMONWEALTH, 1603-1660.

Introduction.-The Tudors left the royal office far more powerful than they had received it; yet this very excess of power proved fatal to the Stuarts. England was now strong abroad and orderly at home. The necessity for an almost absolute government had passed away, and the desire for freedom began to gather strength.

It was, above all, in the affairs of the Church that the Tudors had acted as despots. As heads of the nation, even the Tudors had been restrained by statute and precedent; as heads of the Church, they had succeeded to the indefinite power once enjoyed by the Popes. Elizabeth had employed this power to put down the Puritans, but the Puritans grew stronger under her half-hearted persecution. James I. continued the policy of Elizabeth. The Puritans persevere $d$ in resistance. Charles I. and Archbishop Laud pushèd matters to extremity. The King and Archbishop thought themselves bound in duty to make all members of the Church conform to their system; the Puritans felt bound in duty not to conform. The Long Parliament contained a Puritan majority, and put an end to the persecution of the Puritans. But the Puritans were as intolerant as their enemies. They wanted to remodel the Church of England on their own principles, to abolish the office of bishop and to do away with the Book of Common Prayer. Thus they drove a great part of the nation to take up arms for Church and King. In the Civil War the Puritans 
were successful, but they were now divided into two principal parties-the Presbyterians and the Independents. The Presbyterians were far more numerous in the country, but the Independents formed the bulk of the army. The Presbyterians had no one pre-eminent leader, whilst the Independents had in Cromwell a leader who was at once a great general and a great statesman. At length the army purged the Parliament of all opponents, put the king to death, and made the Independents masters of the three kingdoms.

Then Cromwell took a further step and dispersed the remnant of the Parliament which had claimed to control the army. He hoped to restore order to England by his personal authority, and with this object he would willingly have granted a wide toleration; but he never succeeded in reconciling the mass of the nation to his government. The Presbyterians as well as the Anglicans and Roman Catholics were bitterly hostile to him. When he died, there was no longer any one who could control the army or strike awe into the nation. His son Richard was soon deposed. Then all parties joined to bring back the Stuarts and to restore the old Constitution of England. It was understood that thenceforward there should be liberty of conscience, at least for Anglicans and for Presbyterians.

Thus from the accession of James I. to the accession of Charles II., religion was the most potent influence in politics. It is this circumstance which gives so peculiar a character to the constitutional history of that period.

Character and Reign of James I.-James was an able but not a wise man. The two main objects of his policy were the maintenance of peace and the assertion of his own authority. At the beginning of his reign he concluded a peace with Spain, and ever afterwards he was resolved to avoid wars of religion. Anxious to form a yet closer connection with the Catholic Powers, he carried on a long negotiation to obtain a Spanish princess for his son Charles, and afterwards secured for him a French 
princess. These proceedings were premature, and therefore unwise, as they increased the general suspicion of Catholic influence in the Court of England.

James was disposed to tolerate the Catholics; but his experience of the domination of the Presbyterian clergy in Scotland made him hostile to the Puritans. His disposition to persecute them led to constant friction between Crown and Parliament ; for the House of Commons was still more Puritan now than it had been in the reign of Elizabeth.

James expected everybody to be schooled by himself. He could not understand why the Pope or Catholic kings should harden themselves against his learned schemes for a compromise to be accepted by the Roman and the Reformed Churches; nor could he understand why any of his own subjects should obstinately worship in a manner which he thought unseemly, or insist on a church government which he thought disorderly. $\mathrm{He}$ wanted, in fact, to be master, although he had neither the tact needed to manage men, nor the energy needed to overbear them. Owing to this unhappy temper, some of the best schemes of his reign came to nothing. Thus he wanted to make a perfect union between the two kingdoms of England and Scotland, but he could not overcome the prejudice and sluggishness of the House of Commons. Again, the House of Commons wished to commute the old and vexatious feudal claims of the Crown upon the tenants-in-chief for a fixed annual sum to be settled on the Crown, but they could not settle with James what that sum should be.

Constitutional Progress during Reign of James I.The constitutional progress of this reign may be considered under the following heads :-

I. Taxation.-James was very extravagant. As he was rarely on good terms with his Parliaments, he could not get much money from them. He was therefore driven to unconstitutional expedients. He had received from his first Parliament the usual grant of customs, tunnage, and poundage for life, but he claimed the right to add fresh 
duties or impositions on imported merchandise. In 1606 a Turkey merchant named Bate refused to pay such a duty on currants, and thus brought the question whether the duty was lawful before the Court of Exchequer. The court decided that none of the laws which restrained the king from levying taxes without the consent of Parliament applied to levying duties on foreign goods imported into England. James took advantage of this decision to increase the impositions. Successive Parliaments protested against them, but protested in vain. James went still further; he took a Benevolence in $16 \mathrm{I} 4$, and a second Benevolence in 1620 . His Ministers were careful to explain that nobody was forced to give, but everybody understood that a refusal would call down the king's displeasure.

II. Legislation.--In this reign the right of the king to issue proclamations was for the first time closely defined The House of Commons complained to the king in 1610 that he had issued many proclamations which either forbade the doing of things not forbidden by law, or inflicted on unlawful acts heavier penalties than the law authorised, or directed offenders to be tried before courts which had no power to try them. James referred this complaint to Lord Chief-Justice Coke and the other judges of the Court of King's Bench. Having consulted together, they told the king that he had no power to issue proclamations like those of which the Commons had complained. He might issue proclamations calling the attention of his subjects to this or that law, and warning them that it would be strictly enforced. More he might not do. This opinion of the judges did not, however, put a complete stop to the evil it condemned.

III. Responsibility of Ministers.-Under James I. the House of Commons again began to enforce the responsibility of Ministers, but it confined itself to prosecuting offences against the law. It sent up to the House of Lords the charges of corruption against Lord Chancellor Bacon. He was dismissed and punished. A few years later, the Treasurer, Lord Middlesex, was formally im- 
peached of corruption by the Commons at the bar of the Lords. He had been guilty of dishonesty in his office, but would hardly have been brought to account had he not quarrelled with the Duke of Buckingham, the king's all-powerful favourite.

The Administration of Justice.-During the reigns of James I. and Charles I. the battle of the English Constitution was frequently fought in the courts of law. These kings were always trying to enlarge their prerogative. The friends of liberty rested their opposition on the statutes, from the Great Charter downwards, which had limited the royal power, but the language of such statutes was often vague or obscure. At the present day all doubts due to this cause would be removed by new statutes, but in the period of which we are speaking the king would not have consented to any explanatory law which tended to lessen his power, whilst the Parliament would not have passed any explanatory law which lessened the liberty of the subject. The meaning, therefore, of any doubtful enactment could be determined only by raising the question in an action at law, and thus obtaining the decision of the judges.

At this time the judges held office during the king's pleasure. James took advantage of this fact to put pressure on the judges. He required the judges to confer with him before deciding any question which concerned his prerogative. Lord Chief-Justice Coke was dismissed from his office in 1616 because he had asserted the authority of his own court against the Court of Chancery and the ecclesiastical courts.

The Church.-James I. took the side of the bishops against the Puritans. On his accession he summoned representatives of both parties to a conference at Hampton Court, but he did not act as an impartial president. Soon afterwards Convocation issued a new set of Canons, by which every one who did not admit that the whole of the Prayer-Book was agreeable to the Word of God became liable to excommunication. Excommunication at 
this time rendered the offender liable to imprisonment until he owned his fault and made submission. In consequence of these measures, many Puritan clergymen were deprived of their livings. But Abbott, who became Archbishop of Canterbury in I6I I, was himself inclined to the Puritan views, and succeeded in blunting the edge of persecution for the rest of the reign.

Character and Early Years of Charles I.-Charles had less ability and more courage than his father. He had been brought up in overweening notions of royal prerogative, and he was a zealous Episcopalian. Always convinced that he was in the right, he could not imagine that any of his subjects were honest in differing from him on questions of politics or religion. Without being able to form a clear plan of action or to strike hard at the right moment, he was obstinate and unteachable. Highly conscientious in some respects, he was, notwithstanding, most shifty and disingenuous. No man could have been less suited to be a king in times of change.

His troubles began with his first Parliament (1625). Having inherited a war with Spain, he was in great want of money. The Parliament were unwilling to grant him money, but anxious to discuss the affairs of the Church. So he dissolved this Parliament two months after it had met. In his second Parliament (I626), Sir John Eliot persuaded the House of Commons to impeach the Duke of Buckingham, as responsible for the miscarriage of the war with Spain, and for all the other evils of the time. It was only by dissolving this Parliament that Charles was able to save his favourite.

He was now so foolish as to begin a war with France. Having obtained no money from Parliament, he raised a forced loan. Although the judges would not acknowledge the forced loan to be lawful, the Privy Council took severe measures with those who refused to lend. Noblemen and gentlemen were sent to prison, and men of humbler rank were impressed to serve as soldiers. Five of the gentlemen imprisoned sued for their writ of Habeas 
Corpus, but the judges, with some hesitation, declared that they could not thus recover their freedom. This is often referred to as "The Five Knights' case."

The military operations against France failed altogether, and two circumstances increased the public anger. One was the billeting of troops on the country people; the other was the exercise of martial law over soldiers, and even civilians, who were found assisting in breaches of discipline; for at this time martial law, except on the scene of war, was not known to the English Constitution.

Want of money forced Charles to call a third Parliament in 1628. After much resistance, and in return for a considerable grant of money, this Parliament procured the king's consent to the famous Petition of Right. The Petition of Right condemned (I) taxation without the consent of Parliament; (2) arbitrary imprisonment; (3) billeting of soldiers on the people; (4) martial law. This was the first great concession obtained from the Crown for two hundred years, and the most important concession made since the Confirmation of the Charters in 1297.

But the passing of the Petition of Right was only the commencement of fresh disputes. The House of Commons alleged that the prohibition of taxation without the consent of Parliament was meant to cover the levying of customs and impositions. Charles denied this, and prorogued the Parliament. Sir Thomas Wentworth, who had led the House of Commons in their opposition, now came over to the king's side, and was soon afterwards appointed President of the Council of the North.

The Parliament reassembled in 1629 . The controversy about tunnage and poundage was renewed. The Commons prepared to attack the bishops. Charles thereupon dissolved the Parliament and threw the leaders of the opposition into prison. Eliot died in the Tower, and Valentine and Strode remained there until the meeting of the Short Parliament in 1640. Charles now resolved to govern without calling any more Parliaments. He did 
so for eleven years. During this time Wentworth was his chief political adviser.

The Absolute Government of Charles I, 1629-40 -As Charles intended to govern without a Parliament, he had to raise money by various unconstitutional methods. In order to succeed in doing this, he had to put pressure on the judges, that they might declare his doubtful proceedings to be legal. In order to subdue the discontent thus excited, he had to employ constantly the extraordinary courts of justice which had been developed under the Tudors. But there was one thing for which Charles cared even more than for his own authority. This was the enforcement of conformity to his ideas of church government and public worship. Thus the grievances of this period may mostly be ranged under the three heads of Taxation, the Administration of Justice, and Religion.

Taxation.-The first Parliament of Charles I. had only offered him tunnage and poundage for one year - It had been dissolved before even this grant could be completed. Thenceforward Charles levied the whole of the customs, tunnage, poundage, and imposicions by his sole authority. He maintained that the Petition of Right did not affect the king's right to levy such duties.

Ship-money.-The royal navy at this period was still very small. In time of war it had been usual to impress merchant ships with their crews to reinforce the fleet, assessing each port at so many ships, and requiring it to provide the money for their proper equipment. This was the tax known as ship-money. In 1634 the AttorneyGeneral Noy suggested that ship-money should again be levied, although there was no war. Writs demanding shipmoney were therefore issued in the autumn of that year. Some seaports complained that they were too heavily rated in comparison with others, but only London alleged that the demand was unconstitutional. Even London did not venture to refuse. In the following year another writ was issued requiring ship-money, not from the maritime counties only, but from the whole kingdom. Again 
there were loud murmurs, but again the tax was paid. A third writ was issued in 1636 . This time John Hampden boldly refused to pay. He was a wealthy gentleman of Buckinghamshire, and he was only assessed at twenty shillings; but he knew that if the king could take twenty shillings without the consent of Parliament, he miglt take any man's goods. In the following year Hampden's case came before the judges. They had already declared that the king was lawfully entitled to ship-money. But now two judges pronounced it unlawful, and three decided in favour of Hampden on grounds peculiar to his case. Seven judges gave their opinion for the king. So small a majority was almost as bad as a defeat; yet the king continued to levy ship-money. The fourth and last writ of ship-money came forth in January 1639 .

Other Financial Expedients.-Distraint of Knighthood.-Another means of exaction was the enforcement of obsolete laws and doubtful claims of the Crown. Edward I. had required every freeholder having land of the value of $£ 20$ a year to receive knighthood, or to compound for his failure to do so. Edward had intended by this measure to increase the military force of the kingdom and to lessen the power of the great nobles. Times had changed, and neither of these reasons applied to the state of things in the seventeenth century. Yet Charles enforced this obsolete law simply in order to get the compositions of those who did not wish to receive knighthood. In this way he received at various times large sums of money.

Enlargement of the Forests.-Another expedient of the same class was the enlargement of the royal forests. Royal commissioners were sent to perambulate the forests, that is, to trace their boundaries, and to reclaim any land which might at any time have been included in them, no matter how weak the evidence might be. Land thus brought within the forest bounds became subject to the forest laws and the forest courts, which, although limited by the ancient Charter of the Forests, were extremely oppressive. The inhabitants were thus reduced to pay 
large sums for the privilege of having the land disforested, and so brought back under the ordinary laws.

Sale of Monopolies. - The creation of monopolies was an old grievance. Elizabeth had created so many as to awaken general dissatisfaction; but when the Parliament of 1601 expressed this dissatisfaction in strong terms, she replied with a gracious message, saying that she had been misinformed, and withdrawing all the monopolies. James I. had created so many new monopolies as to excite greater discontent than ever. Monopolies had been declared unlawful by an Act of Parliament passed in 1624 ; but it was pretended that this Act forbade the grant of monopolies to individuals only, not to companies. Charles accordingly raised money by selling monopolies to companies which had been incorporated in order to buy them. The following is one instance out of many :-Charles incorporated a company of soapmakers, which, in return for a payment of $£ 4$ on every ton of soap made by it, received the right of testing the soap of all other makers, and of preventing its sale if unsatisfactory. The Privy Council went so far as to write letters to the justices of the peace recommending the company's soap. Then the independent soapmakers united to buy out the company, and took over its privileges upon condition of paying $£ 8$ per ton to the king. Thus commerce was hampered with absurd restrictions in order to bring a paltry sum into the Treasury.

Exorbitant Fines.-Still worse than the sale of monopolies was the practice of imposing exorbitant fines upon offenders, not so much by way of punishment as to enrich the Crown. It is only fair to observe, however, that these fines were often remitted, in whole or in part, upon the offender making a humble submission.

Administration of Justice.-Like his father, the king put pressure upon the judges. He dismissed Lord ChiefJustice Crew in 1626 for refusing to acknowledge that forced loans were lawful. On several occasions he sent for the judges in order to obtain by personal influence a 
decision in his favour. He was usually successful on these occasions, but the judgment of a court of law, formerly so influential with Englishmen, lost most of its weight when it was known that the judges were no longer independent.

Whilst the courts of common law were thus constrained to pervert the law, the Star Chamber and similar courts were employed to punish all who resisted or criticised the king's policy either in Church or State. Exposure in the pillory, whipping, branding, cutting off the ears, indefinite terms of imprisonment, and enormous fines were among the punishments inflicted upon such offenders.

Religion.-Upon Abbott's death in I633 Charles made William Laud Archbishop of Canterbury. Laud was not a bad man. He was not so narrow-minded as many of his Puritan enemies. He was willing to allow considerable freedom of thought to learned men, but he hated all popular controversy on theological subjects. He wished all public worship to conform to one exact model, which was not to be altered or criticised. He loved splendour in buildings and vestments. He insisted on an elaborate ritual. Above all, he was determined to maintain the authority of the bishops. As the king agreed with Laud in all these opinions, Laud was zealous to magnify the king's authority. The king, as head of the Church, was to assert her cause against both Catholics and Puritans. The Church in return was to teach her children the duty of absolute submission to the royal will.

Thus it was that Charles and Laud excited the bitter hatred of the Puritans. The Puritans regarded them as tyrants who were suppressing pure religion, and traitors who were beguiling the Church back into Roman Catholicism. But the Puritan controversialists were brought before the Star Chamber, and often punished with shocking cruelty. Puritan clergymen were summoned before the High Commission Court and admonished or suspended. Puritan congregations were compelled to accept a form of worship which they abhorred. Harassed, but not crushed, the Puritans became more narrow and intolerant than 
formerly. At one time they had objected only to certain forms and ceremonies; now they became bitterly hostile to Episcopal government. Some went farther, and held that there should be no uniform church government at all. Every congregation, they said, should be self-governing.

The Scotch Rebellion and the Short Parliament.The system of government just described might have endured some time longer had not Charles attempted to force the English Liturgy upon the Scotch people (1637). This attempt provoked what was really a rebellion, although disguised under forms of loyalty. The Scotch entered into the famous agreement known as the National Covenant, by which they bound themselves to maintain the Presbyterian form of religion and the authority of the King ( 1638 ). They levied an army to defend their cause. Charles tried to suppress their resistance, but found that he was not strong enough to do so without the assistance of Parliament. He therefore summoned his fourth Parliament in the spring of 1640 . When this Parliament met, it wanted to begin with the redress of grievances; Charles wished it to begin with granting him money. The dispute thus arising led Charles to dissolve this Parliament. It had sat only two months, and is known as the Short Parliament. Charles again tried to suppress the Scotch by his unaided power; but the Scotch invaded England, and seemed likely to take York. As a last resource, Charles assembled a great council of peers in September. Such a great council, resembling those of the Norman kings, had not been called for more than two hundred years. But the peers strongly disapproved of the King's arbitrary government in Church and State; they therefore advised the king to call another Parliament. Charles found himself obliged to take their advice. He issued writs for a general election. The new Parliament assembled in November of that year. This, the fifth and last Parliament of Charles I., is known to history as the Long Parliament.

The Long Parliament.-The Long Parliament was not 
finally dissolved until the year 1660, when it was almost twenty years old, but its term of real power ended in 1648, when it was purged of most of its members. Its history during these eight years may be divided into several periods.

I. Period of Unanimity in Reform.-This period lasted only for a few months, from November 1640 to August I6́ I, but it was full of momentous business. The Parliament began with calling the Ministers of Charles to account. These Ministers felt that their heads were in danger. Windebank, who had been Secretary of State, and Finch, who had been Lord Keeper, saved themselves by flight. Wentworth, now Earl of Strafford, was actually impeached, and when the impeachment seemed likely to break down, was condemned by an Act of Attainder and executed. He was charged with treason, but the only treason known to the law of England is treason against the king. Such treason Wentworth had never committed. To the king he had been only too faithful. He had attempted to make Charles independent of Parliament. He had counselled or approved most of the unlawful acts of the last twelve years. He had offended against the Constitution of England and the rights of the people, and for this he was punished. $\mathrm{He}$ might have had a lighter punishment had not the House of Commons been convinced that the king would recall him to power at the earliest opportunity. "Stone-dead hath no fellow," said the Earl of Essex when a friend interceded with hin to help in saving Strafford's life.

At the same time Laud, Archbishop of Canterbury, was impeached on a charge of treason. His real offence was similar to that of Strafford. He had been the king's adviser in ecclesiastical affairs, as Strafford had been the king's adviser in civil affairs. The advice which he had given the king had been contrary to the wishes of the nation. Here again the Commons were disposed to be cruel, because they knew that Charles would not rest until he had recalled to his counsels the man whom they 
termed a traitor. But Laud was less dangerous than Strafford. He was left in prison for the present.

The Long Parliament was also unanimous in taking away from the king every pretence for raisirg a revenue without the consent of his people. It passed a Tunnage and Poundage Act, which, while granting these duties for a very short period, declared that no customs duties whatever could be imposed without the consent of Parliament. It passed another Act declaring ship-money illegal, a third for the limitation of the royal forests, and a fourth forbidding the distraint of knighthood. Taken together with the Petition of Right, these Acts made it impossible to carry on the government without the goodwill of the House of Commons.

The Long Parliament was also unanimous in abolishing all the extraordinary courts of justice which had been founded by former sovereigns. It abolished the Star Chamber, thus ending the criminal jurisdiction of the King's Council. Together with the Star Chamber it abolished the Council of the North and the Council of Wales. It abolished the Court of High Commission, and deprived ecclesiastical courts of the power to inflict fine, imprisonment, or corporal punishment of any kind upon any of the king's subjects for any offence whatsoever.

In order to protect itself whilst making these momentous changes, the Long Parliament had forced the king to accept a Bill providing that it should not be dissolved, prorogued, or adjourned without its own consent. In order to protect the country against any future attempt on the part of the king to govern without a Parliament, it passed the first Triennial Act. This Act provided that a new Parliament must always be summoned within three years after the last meeting of the previous Parliament. No Parliament was to be continued by prorogation or adjournment for more than three years from the last day of its last meeting. The Lord Chancellor was to issue the writs for election within a week after the roth of September in the third year. On his failing to do so, the peers were $\mathrm{cm}$ - 
powered to meet and issue the writs. If the peers failed, then the sheriffs of the counties and the mayors of the boroughs were empowered to hold the elections without waiting for any writs. Lastly, if the sheriffs and mayors failed in their duty, the citizens and freeholders were authorised to proceed to the election without waiting for any official notice.

Thus, when the Long Parliament was adjourned in August I64I, the Constitution of England had been brought very nearly into its present form. The responsibility of Ministers to Parliament, the power of the purse in the House of Commons, the supremacy of the common law and of the regular courts of justice, had been asserted beyond the possibility of doubt or dispute.

II. Period of Division ending in the Civil War.Thus far the House of Commons had been practically unanimous. If there were any members who disliked what had been done, they were too few even to murmur. But now this concord was to end. Those who had condemned the tyranny of Charles in the State and of Laud in the Church began to separate themselves into two great parties, the forerunners of the great parties of the present day. The points of difference between these parties were principally two, the one political, the other religious.

Political Differences.-Many who had condemned the unconstitutional acts of Charles now thought that reformation was complete. They did not wish to alter the old Constitution of England. They could not conceive how government was to be carried on unless ample powers were still left to the king. They felt for the king himself a personal loyalty, almost as strong as family affection or religious reverence. They were alarmed by the signs of disorder and turbulence which had lately appeared in London and elsewhere. For all these reasons they wished to go no farther in political change. Hyde and Falkland were the most distinguished men of this party.

But another large body of men were not so easily satisfied. They put no confidence in Charles. They 
thought him false and shifty. They feared that as soon as Parliament was dissolved he would return to the bad old ways, choose new instruments of tyranny to take the place of the Ministers who had been punished, and find new means of breaking the laws which he had accepted. The Parliament might be strong whilst it was sitting, but, when it was dissolved, its members would be so many private men; for in those days there was hardly any organisation of party outside the House, no means of communicating intelligence rapidly to all parts of the country. Meantime the king would remain the head of the executive government, and would be able to crush all his enemies one by one. These men thought therefore that, having done so much, the House of Commons must, in prudence, do more. It must obtain control over the executive government; it must determine who should be Ministers of the Crown. Charles must be deprived of the power which his father and the Tudors had enjoyed; he must be reduced to that condition in which later kings were placed by the Revolution of 1688 . Hampden and Pym were the leaders of the party who thought thus.

Charles had taken a step which, if followed up, might have extricated all parties from this difficulty. He seemed to yield to the feelings of his Parliament. In the beginning of 1642 he asked John Pym, the leader of the Puritans in the House of Commons, to become Chancellor of the Exchequer. Nothing came of this offer. He then offered the same post to Sir John Culpepper, and made Lord Falkland Secretary of State. These men were not Puritans, but they had been leaders in the struggle for constitutional freedom. Had Charles taken this step earlier, he might have saved himself much trouble. It was now too late to regain the confidence of the House of Commons, and Charles never gave his confidence to the new Ministers. They had no influence upon his policy.

Religious. Differences.-It is possible that the difference of political opinion might yet have been overcome 
but for the difference about religion. This difference arose in the following manner:-

All, or almost all, the members of the House of Commons were zealous Protestants. They almost all thought that it was the first duty of the State to maintain true religion and to suppress false religion. They almost all held that there should be only one National Church, and that every species of nonconformity should be repressed. They would almost all have agreed that it was right to persecute Roman Catholics-at least, to exclude them from office, power, or privilege of every kind. As they would have treated Roman Catholics, so they would have treated the petty dissentient bodies of Anabaptists, Separatists, and others, which began to appear about this time. But whilst they agreed that in time to come, as in time past, there should be one National Church, they differed as to the discipline, as to the worship, and in a less degree as to the doctrine which should prevail therein. Many of those who had condemned Laud's meddling rule, his love of ceremonial, and his cruelty to those who differed from his opinions, still preferred the Episcopal to the Presbyterian Church government, loved the Book of Common Prayer, and loathed the bareness and austerity of the Puritan model. Others thought that the necessary reformation of the Church was only begun by Laud's downfall. They wished to suppress the bishops, to discard the liturgy, and to bring the Church of England into conformity with the Church of Scotland.

It was only by degrees that these differences of opinion came to be irreconcilable. Had Charles been a great statesman, he might have brought about some temporary compromise. But Charles only tried to set his enemies at variance in the hope of regaining his own power; and thus the breach grew wider until it ended in civil war.

III. The Long Parliament at War with the King.When the Civil War broke out, the moderate party under Hyde and Falkland joined the king, and so left the 
advanced party under Pym and Hampden masters of the Parliament. As the best men on both sides fought with regret, there were several attempts to make peace; but all these attempts were baffled by the two difficulties already mentioned. The king would not part with the power of choosing his Ministers and governing the country. Neither the king nor the Cavaliers would allow the Church to be remodelled in the Presbyterian fashion. The leaders of the Parliament dared not trust the king with the substance of power. Both leaders and followers were determined to force the Presbyterian system upon the country. Neither party would admit the idea of religious equality. So they fought on, each contending for an impossible mastery.

At first the king had the best of the war. Then the Parliament subscribed the Solemn League and Covenant and invited the Scotch army to enter England. By this means they conquered all the north of England. Now the Presbyterians seemed certain of triumph ; but in times of revolution it usually happens that power passes into the hands of the men who are ready to go the greatest lengths. The new sect of Independents was small in numbers, but great in genius and in courage. Full of zeal for their own doctrines, the Independents thought the tyranny of presbyters almost as bad as the tyranny of bishops. They saw the folly of the Presbyterians in wishing to keep Charles as king of England, yet expecting him to enforce with all his power a system of Church government which he thought irreligious and abominable. So the Independents under Oliver Cromwell went to work in their own way. First they made themselves masters of the army by the Self-Denying Ordinance of 1645 , which discharged members of either House from military commands. Then they remodelled the army and inflicted a decisive defeat upon Charles at Naseby. Thenceforward the struggle for power lay between the army and the Parliament. Each of these parties tried to come to some agreement with the king. 
The king tried to set the one against the other. At last the army lost patience. Having defeated a Royalist invasion from Scotland, they purged the House of Commons of all Presbyterian members, brought Charles to a public trial, condemned and executed him, suppressed the House of Lords, and proclaimed England a free Commonwealth.

The Army and the Rump.-Political power was now monopolised by the army and by the remnant of the Long Parliament, which was known as the Rump. It was enacted that the government of the kingdom should be carried on by a Council of State, consisting of forty-one persons, and by the House of Commons. A few of the excluded members were allowed to return, and elections were held in those constituencies which could be trusted to return men favourable to the party now in power. For the time the army and the House of Commons were in accord. Enemies surrounded the new Commonwealth on every side, but all were overcome by the genius and energy of Cromwell. Ireland and Scotland were conquered and the Cavalier party was shattered. But, when danger passed away, the army and the Rump began to quarrel. The army wished for a regular Constitution, such as had been sketched in the document known as the Agreement of the People, recently presented to the House of Commons by the officers, and for a new Parliament. The Rump wished to retain power in its own hands. At length the dispute was settled by Cromwell, who expelled the members from their House in April of 1653 .

The Rule of Oliver Cromwell.-From this time to the day of his death, Cromwell was really king of England. He showed high courage and ability and gained great renown, but he failed in all his efforts to place the government upon a regular footing. He was in many respects a man of conservative opinions. He would gladly have submitted to the restraints of a Constitution if only his right to act as king were fully acknowledged. 
He wished the nobility and gentry to take that part in public affairs which they had taken under the lawful kings of England. $\mathrm{He}$ wished to maintain a regular clergy supported by tithes and not constrained to any rigid uniformity. He was ready to tolerate quiet men of all religions. He was anxious to enforce the old common law, only making a few reasonable amendments. But he found that the leader of a revolutionary party can never become a constitutional king. The Cavaliers despised him as an upstart and abhorred him as the murderer of King Charles. The Presbyterians hated him almost as bitterly because he had broken down their narrow domination. The Levellers, Anabaptists, and other fanatics hated him because he maintained order. Many even of his own party, the Independents, who were mostly republicans, suspected him of wishing to become king, and thought him little better than a traitor.

The Little Parliament.-Cromwell and the army, having got rid of the Rump, called a new assembly, which is usually known as the Little Parliament, or as Barebones' Parliament. It was nominated by Cromwell and the officers, and contained a hundred and forty-four persons. Six members came from Ireland and five from Scotland. Most of them were upright and pious men, according to the standard then accepted. They met on the $4^{\text {th }}$ of July I653, and entered upon the reform of abuses. Some of their ideas were reasonable, others absurd. Finding their task beyond their strength, they resigned their powers into the hands of Cromwell (12th December 1653).

The Instrument of Government.-The leading officers of the army now agreed on a new Constitition, which they embodied in the document known by this name. Under the Instrument of Government, Cromwell was to become Lord Protector of the Commonwealth. He was to be assisted by a council which was to have a voice in filling up its own vacancies and to choose Cromwell's successor. A new and free Parliament of one House only was to be called. It was to contain representatives of the three 
kingdoms-England, Scotland, and Ireland. A uniform and rather high qualification was made for electors. Decayed towns were disfranchised, and rising towns obtained representation - Parliaments were to be triennial, and were to sit at least five months without hindrance. Cromwell accepted the Instrument, and was solemnly installed as Lord Protector on the 16th of December I653.

The Parliaments of the Protectorate.-The first Parliament of the Protectorate assembled in September 1654. Royalists had been excluded, but republicans were very numerous. Cromwell was reduced to purge it of such as questioned his authority. Even then it did not work well, and he dissolved it as soon as possible.

In September 1656 he called another Parliament. . This also had to be purged of extreme republicans. The remaining members wished to render the Constitution more monarchical. By the Humble Petition and Advice which they sent up to Cromwell in March 1657, he was empowered to nominate his successor and to form an upper House of Parliament. But, when they reassembled in the beginning of 1658 , they did not work harmoniously with the new House of Lords which Cromwell had formed out of such materials as were available. Cromwell had to dissolve this Parliament also, and ruled without a Parliament until his death in September of the samer year.

His son Richard succeeded, and summoned a third Parliament in 1659. It offended the army, and the army compelled Richard to dissolve it. Then the army recalled the Rump, and Richard laid down the Protectorate.

The Restoration.-The army and the Rump presently quarrelled again. The Rump was expelled once more. Everything was now in confusion. The army was supreme, but the army had no master-mind to guide it. Before the end of the year the troops again restored the Rump. In the beginning of 1660 General Monk marched southwards with the army which had been stationed in 
Scotland. Soon after entering London he declared for a free Parliament. Thereupon the members of the House of Commons who had been expelled in 1648, as well as the Lords temporal, resumed their seats, and the Long Parliament, thus reconstituted, finally dissolved itself.

A Convention Parliament, that is, a Parliament not regularly summoned by royal writ, met at the end of April. Its general feeling was in favour of a restoration of the monarchy. Indeed it had no other means of putting an end to anarchy. General Monk had already communicated with Charles, who was living in exile at Brussels. Charles went to Breda, in Dutch territory, and thence sent to the Parliament a declaration in which he offered freedom of conscience, an indemnity for past offences, and payment of the arrears due to the army. The Parliament on receiving this declaration acknowledged Charles as king, and he returned to England in May. 


\section{CHAPTER $\mathrm{X}$.}

CHARLES II.-FAMES II.-THE REVOLUTION AND WILLIAM III., I660-1702.

Introduction. - The Restoration had been carried out by the union of men of all parties, who feared the continuance of military rule and longed to return to constitutional government. With the lawful king the old institutions in Church and State were restored. Careless observers might have fancied that no result remained from all the turmoil of the Civil War and the Commonwealth. But this was not the case. The past could not be blotted out. The restored monarchy was very different from the monarchy of James I. or Elizabeth. A successful rebellion, the trial and execution of a king, the many political experiments which followed, had all taught the nation the lesson of its own strength. The middle classes in town and country had learnt their own military and political power. It was impossible that they should endure the revival of the old forms of oppression. It was certain that a king of England who wished to reign in peace must be very careful to keep within the limits of the Constitution.

But the Stuarts were incapable of grasping the lessons of experience. No sooner had they been restored than they began to work towards the fulfilment of their old ambition. Charles II. would gladly have made himself absolute. He was, however, so prudent as always to draw back before any strong expression of national feeling. His brother, James II., had less sense and more energy. He showed that he had no respect either for the law or for the 
prejudices of his subjects. He thus provoked all parties to unite in deposing him. The Revolution of $1688 \mathrm{com}-$ pleted what the Long Parliament had begun. Power passed irrevocably from the king to the Houses, especially to the House of Commons.

The Convention Parliament.-This Parliament, elected by a coalition of parties, followed a moderate policy. The army was paid and disbanded. An Act of Indemnity pardoned, with some few exceptions, all the offences committed within the past twenty-three years. The Crown, the Church, and the Cavaliers recovered such of their lands as the revolutionary government had sold. Provision was made for the expenses of government in the future. Tunnage and poundage were voted to the king for life.

Abolition of Military Tenures. - The Convention Parliament carried out a great and lasting reform in the abolition of military tenures. The military tenure of land had begun to lose its meaning from the time when Henry II. substituted payment of scutage for personal service. Even as early as the reign of Edward III. the feudal army, formed by the tenants-in-chief with their vassals, had been replaced by a professional army, led indeed by noblemen and gentlemen, but recruited by voluntary enlistment. Since the accession of the Tudors the military tenures had become the means by which the sovereign obtained a small revenue for himself at a great loss to the tenantsin-chief. The old rights of wardship and marriage were the means of much oppression. The Court of Wards, which took charge of the estates of minors, was a sink of abuses. The estates were not properly administered, and their value was usually impaired in the course of a minority. Moreover, when the circumstances which once made feudalism necessary had disappeared, it seemed intolerable that the Crown should take the place of the father in choosing guardians and husbands for his children. So deeply were these evils felt, that soon after the accession of James I. the Parliament proposed to the king that these rights 
should be commuted for a fixed annual sum. James was willing to consider the proposal, but could not agree with the House of Commons upon the amount. The Long Parliament had abolished by ordinance the system of military tenure. The nobility and gentry, having been freed from its annoyances for many years, were determined not to permit its restoration. Accordingly the Convention Parliament confirmed the abolition by a statute and commuted the incidents of military tenure for a fixed and hereditary revenue paid to the king. This revenue was to be raised by an excise upon beer, \&c., not, as would have been more just, by a tax upon the lands liberated from feudal burthens. The amount, however, was not large, and the whole nation gained by the extinction of abuses which inflicted so much injury upon agriculture. The Crown still continued supreme lord of all the land in England, but the land was now held by "socage" tenure, which, as we have seen, imposed merely nominal burthens upon the holders. The abolition of military tenures was the last important step in the abolition of the feudal land law in England.

The High Church Reaction.-The Restoration had been brought about by the combined efforts of Anglicans and Presbyterians. Charles had held out hopes of general freedom of conscience. After his return he had issued a declaration in favour of enlarging the National Church to include both parties. Nothing came of this declaration save a useless conference held at the Savoy in London in 1661. The Civil War had been in great part a war of religion, and the zealous Churchmen were resolved to put down the Puritans for ever. Charles did not interfere, as he wished the Puritans to feel that Parliament would not spare them, and that their only hope lay in his indulgence.

The new Parliament, therefore, which met in $166 \mathrm{I}$, passed a series of persecuting statutes.

I. The Act of Uniformity, 166I, required every clergyman, fellow of a college, or schoolmaster to accept every- 
thing contained in the Book of Common Prayer. Under this Act two thousand clergymen lost their livings.

II. The Corporation Act, I66I, compelled all persons holding office in corporate towns (where the Puritans were most numerous) to renounce the Covenant, to receive the sacrament according to the rites of the Church of England, and to declare upon oath that they considered resistance to the king wicked under any circumstances.

III. The Conventicle Act, 1664, forbade, under heavy penalties, any meeting for purposes of worship attended by more than five persons not of the same family, if such worship were not in accordance with the practice of the Church of England.

IV. The Five-Mile Act, I665, forbade any clergyman who had not subscribed the Act of Uniformity or sworn to the doctrine of passive obedience to teach in school or to come within five miles of any corporate town.

By these measures the Cavaliers hoped to extirpate Puritanism and to bring the whole nation once more within the circle of the Episcopal Church. But the attempt proved altogether unsuccessful.

The Royalist Reaction.-This Parliament met in a fever of loyalty to the king and of abhorrence for republicanism. It solemnly declared that there was no legislative power in the Houses without the king, and that the king was sole commander of all the national forces by sea and by land. As the presentation of petitions by large and disorderly crowds had been one of the first symptoms of civil conflict, the right of petition was put under severe restraint. No petition was to be presented by more than ten persons. No petition for alteration in Church or State was to be signed by more than twenty persons, unless it had first been approved by three justices of the peace or by a majority of the grand jury of the county. A Bill to repeal the Triennial Act of I64I was brought in, but dropped. At length, in Ió64, the king demanded its repeal, avowing that he would never suffer a Parliament to come together by the means 
prescribed in that Act. Thereupon the Act was repealed, with a vague proviso that Parliaments should not in future be intermitted for above three years at the most.

Decline of Royalist Feeling.-This Parliament, loyal as it was, did not choose to forego that commanding position to which it had been raised by the great rebellion. It wanted to criticise everything and to control everything. The profligacy of the Court, the corruption of the officials, and the disasters of the war with Holland (1665-1667), confirmed this disposition. In the year I 665 the House of Commons, whilst voting a liberal supply, appropriated it expressly to carrying on the war - a precaution only taken twice since the Lancastrian period. It was taken again in the following year. In the year 1667 Parliament passed an Act for taking account of the supplies which had been voted. Under this Act commissioners of accounts were appointed, and invested with extraordinary powers of audit and inquiry into the public accounts. In consequence of their report, Sir George Carteret, the treasurer of the navy, was expelled the House of Commons for having issued money without a proper warrant. Hyde, who was now Earl of Clarendon and Lord Chancellor, had tried to resist the encroachments of the House of Commons, but in 1667 the Commons impeached him of high treason and forced him to fly the country.

The Cabal and the Declaration of Indulgence.Since the accession of James I. it had become the practice for the king to consult with only a few trusted members of the Privy Council on the most important affairs of State. This practice, however, was regarded as unconstitutional. Some time after the fall of Clarendon, Charles took into his confidence five councillors, of whom Antony Ashley Cooper was the most famous. These councillors were known as the Cabal. The name has been wrongly derived from their initials, but is far older, and signifies any knot of men who act secretly and in concert. With the help of the Cabal, Charles endeavoured to carry out 
a policy of his own. In foreign affairs he wished to ally himself with France; at home he wished to secure the support of the Catholics and Nonconformists. In 1672 he issued a declaration of indulgence, suspending all the laws which imposed penalties on religious opinion. But this step alarmed both bigots and lovers of freedom. When the Parliament met in 1673, it compelled Charles to withdraw his declaration.

Test Act of 1673. - The Parliament now determined to exclude all but members of the Church of England from any public office. By the Act of Supremacy, I 559, every person taking temporal or ecclesiastical office was required to abjure the spiritual authority of the Pope; but there was no penalty for failing to take the oath, and peers were expressly exempted from the obligation to take it. By the Test Act now passed, nobody could take any temporal office unless he first received the sacrament according to the rites of the Church of England, and made a declaration against the doctrine of Transubstantiation. This Act excluded Nonconformists as well as Catholics from office, but it was directed especially against the Catholics, and was therefore supported by the Nonconformists. As a recompense for their assistance, a Bill was brought in to repeal all the Acts under which they were persecuted. But this Bill was lost. Thus the Nonconformists were excluded from all branches of the public service. In consequence of the passing of the Test Act, James, Duke of York, had to resign the office of Lord High Admiral. Clifford, for the same reason, had to resign the office of Treasurer. Thus the Cabal was broken up.

Impeachment of Danby.-After the fall of the Cabal, Sir Thomas Osborne, afterwards Lord Danby, became Treasurer. Against his will, and by the express orders of Charles himself, Danby took part in a discreditable negotiation with Lewis XIV. of France. When this fact became known to the Commons, they impeached Danby of high treason. Danby alleged the command of the 
king for what he had done; but the Commons ignored this plea, thus asserting the responsibility of Ministers to Parliament. Danby then pleaded a pardon which he had secretly obtained from the king, but the Commons held that the king's right to pardon any criminal did not extend to stopping the progress of an impeachment by granting a pardon before sentence had been given. In order to save Danby, Charles first prorogued and then dissolved Parliament. But the next Parliament decided that a dissolution did not break off an impeachment once begun. The first of these questions was settled in favour of the Commons by the Act of Settlement in I7OI; the second was also settled in their favour in the course of the impeachment of Warren Hastings.

The Popish Plot-The Parliamentary Test, 1678.About this time Titus Oates circulated the fable of a Popish plot to kill the king and to enslave the English people to the Church of Rome. This fable was generally believed, and the public went mad with fear. The Parliament, which had sat since I66I, had been becoming more and more hostile to the king, and more and more zealous for the Protestant religion. It now passed an Act compelling all members of either House, before taking their seats, to take the oaths of allegiance and supremacy, and to make a declaration against the doctrine of Transubstantiation and the adoration of the saints. Thus was completed the exclusion of the Catholics from every place of power save one-the throne. Soon afterwards followed the dissolution of Parliament.

Whig and Tory-The Exclusion Bill.-Political excitement now ran as high as in I640. The Court party were for the first time known as Tories, a name originally borne by certain of the native Irish, who turned robbers and harried the Protestants. The country party were for the first time known as Whigs, a popular name for the most fanatical of the Scottish Covenanters. A majority hostile to the Court was returned at the general election. Its leaders introduced the famous Exclusion Bill, which 
was to prevent the succession of James, Duke of York, the king's brother and next heir, but a Catholic. Before it could be passed in the Commons, Charles dissolved the Parliament.

The Habeas Corpus Act, 1679. - In this brief Parliament time had been found for one memorable statute, namely, the Habeas Corpus Act, which for the first time provided effectual security that no man should be imprisoned for an indefinite time without trial. The Great Charter had laid down the principle that no freeman could be imprisoned otherwise than by the lawful judgment of his peers. Any man imprisoned without trial had a right to obtain from the Court of King's Bench a writ of habeas corpus (Latin for "that you have the body"), addressed to the person keeping him in custody, and requiring that he should be produced in court together with the warrant for his commitment, so that the court might at once ascertain the fact of his being kept in custody, and the grounds on which he was confined. 'The court was bound to issue this, writ whenever demanded; but, although the law had thus carefully provided for the liberty of the subject, the power of the Crown had often overridden the law and kept in durance persons obnoxious to the Government. Possible claimants of the throne, like Arabella Stuart, or leaders of resistance to the king's will; like Eliot, Valentine, and Strode, had languished in prison until they were released either by death or by political revolution. Thus further legislation was needed to make the right to personal freedom a reality. The practical effect of the Habeas Corpus Act, as amended by later statutes, is that a person committed on a charge of treason or felony must be indicted at the next assizes or released on bail, unless it is proved that the witnesses for the Crown could not appear at that time; and if he is not indicted at the assizes following, he must be discharged altogether. If he is committed for any offence other than treason or felony, he must be admitted to bail. If he is committed without any offence being laid to his charge, 
he must be released on giving bail to appear in the next term, so that the court may examine into his case. Severe penalties were enacted against the gaoler who should fail to produce his prisoner, and against the judge who should refuse to issue the writ of habeas corpus. The imprisonment of any English subject in any place outside England was forbidden on pain of very severe penalties.

It has not been found practicable always to enforce the Habeas Corpus Act. In times of political disturbance it may sometimes be necessary to confine persons who have not actually raised a rebellion, and against whom the intention to raise a rebellion cannot be proved. At such times the Government of the day has demanded the suspension of the Habeas Corpus Act, and a temporary statute suspending it has been passed.

The Exclusion Bill brought in again-Reaction in the Country.-Another Parliament met in 1679. The Exclusion Bill was brought in again, and was passed by the Commons, but thrown out by the Lords. Charles now dissolved this Parliament. Another Parliament was summoned to meet at Oxford in I68r. It sat just long enough to show that it would be violent and unscrupulous. Charles saw that a reaction was now spreading over England. The public began to feel remorse for the judicial murders committed on innocent Catholics, and disgust for the violence of the leaders of the Opposition. Charles boldly dissolved this Parliament, and never called another.

Despairing of parliamentary success, the leaders of the Opposition now had recourse to conspiracy. But these plots were discovered. William Lord Russell, Algernon Sidney, and others were put to death.

Forfeiture of the Charters.-As the Opposition was strongest in the city of London and the boroughs throughout England, the Government caused informations to be laid against them for having violated the terms of their charters. The old charters having been forfeited, new charters were issued which restricted municipal privileges 
to a very small number of persons in each town. Municipal offices were everywhere placed in the hands of persons whom the king could trust. But whilst care was taken that the majority in the next House of Commons should be in favour of the king, the king resolved not to call any more Parliaments. When he died in 1685, more than three years had elapsed since the dissolution of the last Parliament.

Accession of James II.-One of the first acts of James II. was to order that the customs duties should continue to be paid as before, although they had legally expired with the death of the late king. James, however, thought that he might safely call a Parliament. It proved extremely loyal, and settled upon the king for his life a revenue of nearly $£ 2,000,000$ sterling. The unsuccessful rebellion of Argyle and Monmouth strengthened the authority of James. But when the Parliament assembled for a second session, it proved obstinate in resisting two schemes on which James had set his heart. James intended to secure for the members of his own Church, not merely a fair share, but a monopoly of office and emolument. As a means to this end, he wished to repeal the Test Act. The Parliament saw his object and would not hear of repeal. James also saw that he could not become absolute without the help of a powerful standing army. Hence he wished to add largely to the small force of regular troops which he had received from his predecessor. But the House of Commons abhorred a standing army, and would not grant the additional supplies demanded by the Ministers. James therefore prorogued the Parliament and resolved to govern according to his own discretion.

The King Attacks the Church of England.-James was resolved to make his religion the religion of the people. For this purpose he made use of his ecclesiastical supremacy. He gave ecclesiastical preferment to several avowed or suspected Roman Catholics. In defiance of the Act of the Long Parliament which abolished the 
Court of High Commission, he set up a similar court, the Court of Ecclesiastical Commission, which had full power to inquire into all cases of alleged misconduct in the clergy, and to suspend them from their duty or to deprive them of their livings. Among other acts of tyranny, this court expelled all the Fellows of Magdalen College, Oxford, for refusing to elect as president, Parker, the Catholic Bishop of Oxford.

At the same time James appointed a great number of Catholics to civil and military offices. He claimed to do this by virtue of his prerogative of dispensing with statutes. Having secured the subservience of the Bench by dismissing several judges, he caused a pretended informer to bring an action against Sir Edward Hales, a Roman Catholic, who had received a commission in the army. The judges held that Hales had done nothing unlawful in accepting the commission, since the king could dispense with all statutes to the contrary. Having obtained this decision, James paid no further attention to the Test Act.

The Declaration of Indulgence.-The Roman Catholics in England were at this time so few that James could not trust to them alone if he wished to become absolute; he therefore tried to conciliate the Nonconformists. He issued one Declaration of Indulgence in 1687 and another in 1688. By these declarations he suspended not only the statutes which inflicted penalties upon Roman Catholics and Nonconformists, but also the statutes which excluded them from any kind of preferment. Even if he had been sincerely anxious to grant religious liberty to all, he would have been to blame for these declarations. To publish them was to assert that no law could bind him, that he had in himself absolute legislative power. But James did not really care for religious liberty. He only wanted to ruin the Protestant churches by setting them against one another. Most of the Nonconformists saw that James was not honest, and declined to accept toleration at his hands. 
James had ordered that his second deciaration should be read aloud in every church in the kingdom. Sancroft, Archbishop of Canterbury, and seven bishops, presented to the king a petition remonstrating against this order. James ordered that they should be prosecuted for seditious libel, but the jury acquitted them amid universal rejoicing.

The Revolution of 1688.- - So long as James had no son, the nation was disposed to endure his arbitrary government, and to wait for the accession of his daughter Mary, who had been married to William, Prince of Orange, and was a zealous Protestant. But when a son was born to James in I688, this hope was extinguished. Seven of the principal men in England sent a letter to the Prince of Orange calling upon him to vindicate the religion and liberty of England. He accepted the invitation, and landed in England with an army. James, deserted by all, attempted to fly. He was discovered and stopped by some fishermen of Sheerness. Thence he was brought back to London. William, however, contrived to alarm James once more. Every opportunity of flight was afforded to him. He fled a second time. A Convention was then summoned by William.

The Declaration of Rights and the Bill of Rights.If James II. had remained in England it would have been difficult to dethrone him. Many of those who had hitherto taken part against him believed in his divine right to the throne, and would not have driven him from it by force. But as he had fled to France, it became possible to pretend that he had abdicated of his own accord. The Convention, after many debates, passed a Declaration of Rights, reciting the fact of his abdication, and condemning as unlawful the principal acts by which he had offended the nation. The crown was then offered to William and Mary, and accepted by them. The Convention was turned into a Parliament, which met in January I689. A Bill of Rights, embodying the principal provisions of the Declaration of Rights, was then laid before the House. Its principal provisions were as follows :- 
(I.) That the pretended power of suspending of laws or the execution of laws by regal authority, without consent of Parliament, is illegal.

(2.) That the pretended power of dispensing with laws or the execution of laws by regal authority, as it hath been assumed and exercised of late, is illegal.

(3.) That the commission for erecting the late Court of Commissioners for Ecclesiastical Causes, and all other commissions and courts of like nature, are illegal and pernicious.

(4.) That levying money for or to the use of the Crown, by pretence of prerogative, without grant of Parliament, for longer time or in other manner than the same is or shall be granted, is illegal.

(5.) That it is the right of the subjects to petition the king, and all commitments and prosecutions for such petitioning are illegal.

(6.) That the raising or keeping a standing army within the kingdom in time of peace, unless it be with consent of Parliament, is against the law.

(7.) That the subjects which are Protestants may have arms for their defence, suitable to their conditions, and as allowed by law.

(8.) That the election of members of Parliament ought to be free.

(9.) That the freedom of speech and debates or proceedings in Parliament ought not to be impeached or questioned in any court or place out of Parliament.

(I0.) That excessive bail ought not to be required, nor excessive fines imposed, nor cruel and unusual punishments inflicted.

(I I.) That jurors ought to be duly empanelled and returned, and jurors which pass upon men in trials for high treason ought to be freeholders.

(I2.) That all grants and promises of fines and forfeitures of particular persons before conviction are illegal and void.

(I3.) And that for redress of all grievances, and for 
the amending, strengthening, and preserving of the laws, Parliaments ought to be held frequently.

After claiming these rights for the English people, the Bill proceeded to confer the crown upon William and Mary and their offspring ; and in default of their offspring, upon the Princess Anne and her offspring ; and in default of her issue, upon the issue of William by any wife other than Mary.

Importance of the Bill of Rights.-The Bill of Rights decided in favour of the people and against the king all the principal questions which had been contested throughout the Stuart period. It is, therefore, one of the most important of our statutes, holding the same rank as the Great Charter of John, the Confirmation of the Charters by Edward I., and the Petition of Right under Charles I. But it is even more important as changing the succession to the throne, and bringing in a series of sovereigns who had only a parliamentary title. Nobody could pretend that William, or Anne, or George I. held the crown by divine right. Those who believed most firmly in the divine right of kings regarded these rulers as usurpers. The Tories, who had most reverence for the kingly office; were unfriendly to kings set up by Parliament. The Whigs, who were friendly to kings set up by Parliament, had little reverence for the kingly office. Accordingly the power of the Crown, which had been so great in the seventeenth century, became comparatively insignificant in the eighteenth century. The government of England was thenceforward conducted, not by the king subject to the criticism of Parliament, but by the leading members of Parliament in the name of the king. Parliament had hitherto served as a check upon the supreme power; it now became the supreme power itself.

Appropriation of Supplies-The Mutiny Act.-Two innovations made soon after the passing of the Bill of Rights served to increase the newly gained power of Parliament. The first of these innovations was what is known as the Appropriation of Supplies. 
I. Appropriation of Supplies.-In former times the king, as head of the government, had expended, according to his own discretion, both his hereditary revenue and the sums voted by Parliament. Parliament might grant or refuse the money asked for by the king's Ministers, but it did not pretend to say how the money, once granted, should be spent. It was only on one or two exceptional occasions, when the House of Commons was thoroughly distrustful of the king or his Ministers, that it took measures to secure the proper exp₹nditure of its grants. But the Parliament of 1688 introduced the practice of appropriating the supplies, i.e., of settling how much of the revenue should be devoted to different branches of the government. Having given William a revenue of $£ \mathrm{I}, 200,000$, it determined that one half of this revenue should be appropriated to the civil list-in other words, the civil government-and the other half to the army and navy. From that time the process of appropriation has been carried further and further. At the present day every item of the public expenditure is settled by the House of Commons. The same Parliament granted the excise duties, not as formerly for the king's life, but only for four years. A great war with France, which began about the same time, increased taxation, and led to the establishment of the National Debt. Thus the government became completely dependent upon money voted by the House of Commons. The House of Commons had thenceforward absolute power over the national purse.

II. The Mutiny Act.-The Bill of Rights had forbidden the king to keep a standing army without the consent of Parliament. The intention of this enactment was to do away with a standing army altogether. The Tories hated standing armies, because a standing army had brought Charles I. to the scaffold, and had set up a republic. The Whigs hated standing armies, because James II. had tried to use a standing army in support of his absolute power. All parties wished to intrust the defence of the kingdom to the militia; but this could not 
be done, as we were just entering on a war with the king of France, who possessed the finest regular army in the world. It was necessary, therefore, to keep up the standing army formed by James II. But a standing army cannot be kept in order without special laws to enforce discipline, and special courts to administer these laws. The English Constitution knew nothing of such laws or such courts. When James II. hanged certain soldiers for deserting their colours, he was acting contrary to law. So, when a mutiny broke out in 1689 among a Scotch regiment quartered at Ipswich, the first Mutiny Act was passed to prevent such offences in future. It was to be in force for one year only. It had to be re-enacted, but it was still for a year only; at first because men hoped that there would be no need for a standing army, but afterwards because Parliament was resolved to keep the standing army under its control. In I88I the Mutiny Act was replaced by the Army Discipline and Regulation Act; but this also has to be renewed every year. If it were not renewed, there would be no means of enforcing discipline in the army. The soldier who deserted could only be treated like a workman who had broken his contract; the soldier who struck his commanding officer could only be prosecuted for assault and battery. Thus the standing army can be kept in order only by the assistance of Parliament. Since the Revolution of 1688 Parliament has wielded the power of the sword as well as the power of the purse.

The Toleration Act, 1689.-The greater part of the Nonconformists had honourably refused to join James II. in his attack on the Church of England, and had actively assisted in the Revolution. They had thus established a claim to relief from the persecution endured under Charles II. After the Revolution a last attempt towards the comprehension of Nonconformists in the Church was made, but failed for want of zealous support by any party. A Toleration Act, however, was passed in 1689. Its provisions cannot be fully understood without elaborate 
explanation, but its practical effect was to allow all Protestants, other than Unitarians, to worship God in the manner most agreeable to their own consciences. Thus an end was put to the persecution of all sects other than Unitarians or Roman Catholics. The part of the population still liable to persecution was a very small fraction of the whole.

The Toleration Act takes the same place in the history of the relations of Church and State which the Bill of Rights holds in the history of the relations of king and people. It marks a turning-point in history, the end of one period and the commencement of another. For many centuries after the conversion of England to Christianity there had been one Church of England, coextensive with the kingdom of England. All agreed that it was the duty of the State to see that all its members were also members of the one true Church. When the Church of England became Protestant, the Catholic doctrine of unity was still maintained. The Puritan and the Laudian were alike resolved to tolerate no difference of opinion. Puritan and Laudian alike fought for the power of reforming the Church according to their own ideas, and of forcing others to accept those reforms. Persecution thus became inevitable. The only alternative to persecution was comprehension, which always failed.

The Toleration Act of 1689 was the first legal recognition of diversity of religious opinion. Those who could not bring themselves to accept the doctrine, discipline, and ritual accepted by the majority of the nation were allowed to form separate churches, protected by the law. The Church of England, as by law established, henceforward stood side by side with tolerated Nonconformist Churches. Thus was created the ecclesiastical order, with which we are so familiar that most persons have forgotten how slowly it was reached. It is true that the area of toleration was still narrowly confined. It is also true that the law granted only toleration, not equality. The privileged Nonconformists were still ex- 
cluded by statute from all office and preferment. Nearly a century and a half elapsed before the service of the State was thrown open to men of all religions.

Liberty of the Press.-A change even more important than those above mentioned was brought about almost by accident a few years after the Revolution. This was the liberation of the press. The Tudors, James I., and Charles I., had all kept the press under severe restraint. The Long Parliament had not been more liberal. Soon after the Restoration a law had been passed to enforce a censorship of the press. It had been renewed from time to time, and had finally expired in 1679. Charles II. and his Parliament were then on bad terms. No new legislation on this subject took place until after the accession of James II. In 1685 the Licensing Act was revived for seven years. In 1692 it was continued until the end of the next session, but it was never renewed after it had expired in I693. Thenceforward there was no restraint upon the press other than the law of libel. The law of libel might then be strained to cover all hostile criticism of the Government. Nevertheless, the expiry of the last Licensing Act was a real gain for freedom.. From this time forward the press became a great political power. Under Queen Anne, almost all distinguished literary men wrote political pamphlets; newspapers were multiplied, and began to express opinions as well as facts; a much greater number of persons interested themselves in public affairs.

The Triennial Act.-Now that the House of Commons had become the chief power in the State, there was little danger lest the king should try to govern without a Parliament. It was not necessary to pass a law like the Triennial Act of 164I, forbidding the intermission of more than three years without a Parliament, but it was still possible for the king to keep the same Parliament as long as he pleased, long after it had ceased to represent the wishes of the nation. It was necessary, therefore, to pass an Act for the calling of new Parliaments at reasonable 
intervals. The ancient laws in favour of annual Parliaments had long since become obsolete. By the Triennial Act of 1694 it was provided that every Parliament should cease and determine within three years from its first meeting. The intermission of Parliaments for more than three years was once more forbidden by this Act.

Reform of the Procedure in Trials for High Treason. - The old criminal law of England placed accused persons under several disadvantages. They were not furnished with a copy of the indictment (written accusation) before trial, their witnesses could not be examined on oath, they could not make their defence by counsel. These unjust rules operated with particular cruelty in trials for treason. For the judges were usually under the influence of the Crown, and the ablest lawyers were retained for the prosecution. The only advantage enjoyed by a person accused of treason was given by a statute of Edward VI., requiring two witnesses for a conviction. Throughout the seventeenth century trials for treason had been marked by the grossest injustice and inhumanity. In 1695 an Act was passed to amend the procedure in such trials. It was enacted that a copy of the indictment and a copy of the panel of jurors should be delivered to the accused before trial; that he should be allowed to make his defence by counsel; that his witnesses should be examined on oath; and that no prosecution for treason should be brought after three years from the date of the alleged offence except it were an attempt to assassinate the king.

The Act of Settlement, 1701.-This Act, as its name denotes, was intended chiefly to settle the order of succession to the crown at a time when it became improbable that either William or Anne would leave any issue to inherit after them; but the Act also contained some provisions of great constitutional importance.

(x.) The Sovereign to be a Member of the Church of England.-It was enacted that whosoever should hereafter come to the possession of the crown was to join in communion with the Church of England as by law estab- 
lished. This enactment completed the series of statutes by which persons not in communion with the Church of England were excluded from sharing in the government. Unlike the rest of these exclusive laws, it has been maintained to the present day. It has never caused any hardship, and may be justified on the ground that the sovereign for the time being is also the head of the Church. The example of James II. had proved that a king not in communion with the Church was unfit to be her head.

This enactment also illustrates the decay of the belief in the hereditary right of succession. The Exclusion Bills of the previous generations had been defeated by the force of this belief. But now a Tory Parliament passed a law to set aside the hereditary right of succession whenever the next heir to the crown was not in communion with the Church.

(2.) Attempt to Revive the Privy Council.-Another clause in the Act of Settlement tried to revive the Privy Council. It required that all the business of government formerly transacted in the Privy Council should still be transacted there, and that all resolutions of the Council should be signed by those councillors who had consented thereto. We have seen that in the Tudor period the Privy Council had really governed the country. Under the Stuarts, power had gradually passed to a smaller body of men, in whom the king placed particular confidence. After the Revolution this continued to be the case. The king consulted with a few eminent men, and left to the majority of the councillors only a nominal share in public business. Strict upholders of old constitutional practice took alarm at this innovation. The king could do no wrong; only his advisers could be made responsible. It was therefore essential to know who his advisers were. If once he ceased to take the opinion of the whole council and let himself be guided by the advice of a clique, what security would there be against misgovernment?

Such, no doubt, were the considerations which suggested this clause in the Act of Settlement. But it could 
not alter the natural tendency of things. The rank of privy councillor was often conferred as a mere mark of distinction on men who had neither the wish nor the ability to take part in the government. The Privy Council was too unwieldy for prompt decision. It contained men of all parties, those whom we should call the leaders of the Opposition as well as the Ministers. The real advisers of the Crown continued to be few. The danger of irresponsible government was averted in the next century by the development of the Cabinet system.

(3.) Exclusion of Placemen and Pensioners from the House of Commons. - It was enacted that no person who had an office or place of profit under the king, or received a pension from the Crown, should be capable of serving as a member of the House of Commons. The House of Commons was now supreme in the State. It was no longer liable to be coerced, but it was all the more liable to be corrupted. It was not subject to the check of a vigilant public opinion. Many members sat for constituencies absolutely controlled by some powerful individual or by the Crown. The debates and divisions were not yet published. As the practice of intrusting office to the leaders of the majority in the Commons for the time being was not yet established, the House was often unruly, and tried to embarrass the Ministers. Ministers were thus tempted to have recourse to corruption as a means of managing the House. Corruption might take the form of direct money bribes, or of places and pensions. Against the latter form of corruption this clause of the Act of Settlement was aimed, but it went too far; it excluded even those persons who held the most important offices under the Crown. It cut off the House of Commons from direct knowledge of the business of government. A few years later this clause had to be repealed. It was then enacted that only persons holding offices created since I 706 were to be incapable of sitting in the House; but it was added that a member accepting any office under the Crown, other than a commission 
in the army, should be obliged to offer himself for reelection. These rules are still in force.

(4.) Independence of the Judges.-It was enacted that judges' commissions should be for life or for good behaviour, and that their salaries should be ascertained and established. They were to be liable to removal, however, upon a joint address of both Houses of Parliament. In this way the judges were secured from such intimidation as had been exercised by the Stuarts. The character of the English Bench was effectually raised by this enactment.

Conclusion.-The series of great reforms above described brought to an end the conflict between king and people, first begun by the barons against John, and continued from age to age down to the expulsion of James II. Henceforward the royal power was subordinated to the will of the people expressed in Parliament. England became, as it is said, " a crowned republic." The sovereign retained his pomp and his titles; he retained in form the prerogatives actually wielded by the most powerful of his predecessors. He was still the head of Church and State, the fountain of justice, the captain-general of the national forces by sea and land. But the powers implied in this description could henceforth be used only by permission of the House of Commons, and according to the advice of the men in whom it placed confidence.

Personal Influence of William III.-The real extent of the political change effected at this period was partially concealed by the activity of William. He was far too able and energetic to be satisfied with a nominal sovereignty. He ruled at a crisis in which a real sovereign was sorely needed. He was his own Foreign Secretary, the ablest Foreign Secretary whom England has ever possessed. He was his own commander-in-chief, and led great armies always with honour, if often without success. Not until his death could it be seen how much the power of the Crown had been diminished by the Revolution. 


\section{CHAPTER XI.}

\section{ANNE, GEORGE I., AND GEORGE II.,}

I 702-1760.

Introduction.-The passing of the Bill of Rights and of the other important statutes of William III. marks an epoch in our constitutional history similar to the epoch marked by the Confirmation of the Charters by Edward I. A long period of conflict between different elements in the State was brought to a close; a long period of repose began. The English Constitution, as amended by the Bill of Rights, underwent no formal change for one hundred and forty years. Those years were full of great events. England finally outstripped Holland, and became the undisputed mistress of the sea and the chief carrier of the world's merchandise. She gained from France the supremacy both of India and of North America. Finally, she efferted, by a series of remarkable inventions, such a revolution of industry as had not been known at any period of the past. All these achievements had their effect upon her internal history, and prepared the way for a new period of revolution. But it is not our business to describe them here.

This period of repose, however, is marked by some constitutional changes of interest. In order to understand them more clearly, it is convenient to make a division at the death of George II. ( 1760 ), or rather at the dissolution of the famous Ministry in which the elder Pitt was the real Prime Minister. The three reigns of Anne, George I., and George II. are best considered by themselves.

When Anne became queen, the results of the Revolu- 
tion of 1688 were fairly secure. But it was not yet decided what party should be supreme in the State. Anne, a Stuart by blood, was a Tory and High Churchwoman by conviction. Marlborough, her most powerful subject, could scarcely be called either Whig or Tory. Like William III., he stood above parties, and used them for the execution of his vast schemes of foreign policy. At first he leaned upon the Tories. Finding them intractable, he induced Anne to replace them with Whigs. When Anne became tired of Marlborough and his wife, she brought the Tories back to power. But the accession of the House of Hanover was the triumph of the Whig party. During the next forty-eight years England was governed by the Whigs.

The Whig party at this time consisted first of a number of the noblest and wealthiest landowners, who are often referred to as "the Revolution families;" secondly, of the moneyed and mercantile class, which was daily growing in numbers and riches; thirdly, of the Nonconformists in all parts of the kingdom. The Tories included some of the greater and nearly all the smaller landowners, the inferior clergy, and the bulk of the poorer class who were not Nonconformists. The Whigs were probably a minority, but they possessed more than half of the wealth of England, and a preponderance of her ability and enterprise. They were an aristocratic party of liberal opinions. Under George I. and George II., who were virtually foreigners, they really governed England. With the accession of George III. their power was shaken.

Reign of Anne.-The principal constitutional events of this reign were the parliamentary union of England with Scotland, and the attempt to restore the intolerant Church policy of the reign of Charles II.

The Parliamentary Union of England with Scotland.

I. Unsuccessful Attempts towards Union.-A parliamentary union of his two kingdoms had been a favourite project of James I., but he had been baffled by the indifference of the English Parliament. After conquering 
Scotland, Cromwell had carried out a parliamentary union; but this union had been effected without the consent of the Scotch, who were kept in subjection by an English army. At the Restoration the separate Parliaments of England and Scotland were re-established. The Scotch soon learnt to regret the time when they had enjoyed equal commercial rights with Englishmen. Under an Act of the Scottish Parliament, the king, in 1670, appointed commissioners to treat on behalf of Scotland for a parliamentary union. The apathy of the English again prevented anything being done. Soon after the Revolution of I688 William III. suggested that a parliamentary union should be effected, and the Scotch Parliament passed an Act empowering him to appoint commissioners, but the English would not yet respond. Before his death events occurred showing that either complete union or complete separation must presently ensue. A Scotch company made a rash attempt to colonize the isthmus of Darien, in the very heart of the Spanish possessions. The settlers were expelled by the Spanish forces. The English Government had not supported the settlers, and the English people were accused of rejoicing at their misfortunes. This incident showed that Scotland had all the burthens of independence without its advantages. She was governed by a king of England, advised by English councillors, and depending on an English Parliament, whilst she was excluded from a share in English commerce and colonization, and denied the assistance of English fleets and armies.

William now recommended the subject of the union to the English House of Lords, which passed a Bill for the appointment of commissioners to represent England, but the Commons threw out the Bill in a fit of petulance. After the accession of Anne, however, both Parliaments empowered the queen to name commissioners, and a series of conferences took place in 1702 and 1703 . It soon appeared that the commissioners had no hope of coming to an agreement. The English were anxious to 
maintain their commercial monopoly, and to exclude Presbyterians from office. The Scotch were uneasy for their Church, and bent on sharing in English commerce. These conferences therefore ended in nothing.

II. The Act of Union, 1707.- What finally decided this tedious question was the alarming temper shown by the Scotch nation. Moved partly by resentment on account of the Darien business, partly by Jacobite influence, and partly by intense national pride, the Scotch Parliament passed in 1704 the Act of Security, providing that after the death of Anne the crown of Scotland should not pass to the successor to the crown of England, unless due security were given for Scotch religion and Scotch trade. The English Parliament retorted with a law that henceforward all Scotchmen were to be regarded as aliens, and imports from Scotland were to be excluded. Upon this the Scotch became more moderate, and a new commission was appointed to consider the Union.

In I706 the Treaty of Union was settled. It was agreed that England and Scotland should form one kingdom, to be known as Great Britain ; that their flags should be blended; that their Parliaments should be united; and that Scotland should be represented by sixteen peers and by forty-five commoners. The peers were to be elected for each Parliament by the whole body of Scotch peers, and the Crown was not to create any more Scotch peerages. The Scotch national debt was discharged by England, and Scotland was to contribute to the land-tax $£ 48$,000 for every $£ 2,000,000$ contributed by England. Scotland was to retain her national law and her courts of justice. Separate Acts of the Scotch and English Parliaments provided for the security of the Established Church of Scotland and the Established Church of England respectively, and these Acts were comprised in the same parliamentary ratification with the articles of Union. The Union took effect in I707. The existing English Parliament, with the addition of the Scotch representatives, became the first Parliament of Great Britain. 
Anxiety for the Protestant cause and fear of a restoration of the Stuarts had been the chief motives for the Treaty of Union. It was unpopular in Scotland, and probably would not have been ratified by a thoroughly representative Parliament. But the actual Scotch Parliament was by no means representative of the Scotch people. Nor would the Treaty of Union have obtained favour in England save for the fear of total separation. Both countries, however, benefited by the Union. England was delivered from a constant danger in the existence of a separate kingdom adjoining her borders. Scotland secured her full share in the profits of English commerce and colonization. One of the poorest of European countries at the time of the Union, she has since become one of the most prosperous.

The High Church Reaction. - The Tories in the reign of Anne resembled in their views the Cavaliers of the Restoration. They were well satisfied to keep the constitutional liberties gained at the Revolution, but they were bent on crushing the Nonconformists, with whose help these liberties had been gained.

With this object the Tories brought forward, time after time, a Bill to prevent occasional conformity. Nonconformists had frequently evaded the Test Act by returning to their own worship after they had qualified themselves for office by once taking the sacrament according to the rites of the Church of England. It was proposed to make such conduct penal. The Bill was favourably received by the House of Commons, but was thrown out in the House of Lords, where the Whigs formed a strong majority. At length, in the year I7IO, the Whigs began to fear that the new Tory Ministry would make peace with France. In order to secure some Tory votes for the prosecution of the war, they meanly forsook their friends and consented to the Bill against occasional conformity. In I7I 3 the Tory Ministry passed a much worse measure, the Schism Act, which was designed to hinder Nonconformists from acting as schoolmasters or 
tutors. It seemed as though the Toleration Act itself was in danger of repeal.

Accession of the House of Hanover-The Whig Ascendency.-With the death of Anne the power of the Tories came to an end. The new dynasty was weli aware that from the Tories they could expect only indifference, but that the Whigs were bound to them by the instinct of self-preservation. William III. had found himself similarly situated, but George I. was far less acquainted with English politics than William III. George I. could hardly speak English, and is said to have conversed with Sir Robert Walpole in Latin. George I. interested himself, not as William III. had done, in the politics of all Europe, including England, but in the politics of Germany, especially as they related to Hanover. For these reasons George I. was glad to devolve the care of governing England upon the party which could be trusted to defend his title to the throne. His indifference to English politics had two momentous effects - the one temporary, the other permanent. The temporary effect was to make the Whig party supreme in England; the permanent effect was to reduce yet further the power of the Crown, already so much diminished by the Revolution.

Whig Legislation.-On returning to power, the Whigs relieved the Nonconformists from the persecuting laws passed under Queen Anne. The Occasional Conformity Act and the Schism Act were repealed. The Whig leaders would gladly have gone on to repeal the Test and Corporation Acts, and render Nonconformists as fully capable of holding office as Churchmen, but they were warned by friends that any further progress in religious freedom would provoke a powerful reaction which might turn out the Whigs and overthrow the House of Hanover. They thought it better, therefore, not to attempt the repeal. These Acts remained on the statute-book, but it became the practice to pass an annual Act of Indemnity relieving those who had incurred penalties under them.

The Septennial Act.-Soon after the accession of 
George I. the Jacobites raised a dangerous rebellion in Scotland and the north of England. A restoration of the Stuarts was feared. The strict observance of the Triennial Act would have involved a dissolution of Parliament whilst the public was yet excited. An Act was therefore passed which prolonged the possible duration of a Parliament from three to seven years, and empowered the then existing Parliament to sit for that time. Ever since, the term for which a Parliament can legally sit has been seven years.

The Peerage Bill.-Another measure which never became law deserves to be noted, as illustrating the weakness of the Crown and the aristocratic temper of many of the Whigs. In the session of 1719 the Ministers introduced a Bill for limiting the power of the king to make peers. It provided that the number of peers should never exceed by more than six the number then actually existing, and that the king should have power only to keep the number up to that limit. It would have replaced the sixteen representative peers of Scotland with twenty-five hereditary peers. Had this Bill been carried, the peerage would have become a close body, and a few great families would have obtained an enormous power. The final result might have been disastrous to the House of Lords. The Bill, however, was resisted by many of the Whigs of the House of Commons, especially by Walpole, and never became law.

Development of the Cabinet-Party Government.More important than any legislative innovation made during this period was the development of the Cabinet. Its development was the direct consequence of the Revolution of $\mathrm{r} 688$. But this consequence was not foreseen by any of the statesmen who took part in that revolution. The Cabinet was not the deliberate invention of any one man, nor even of a series of reformers. It took shape gradually, and under the pressure of circumstances. None of the authors who in the last century wrote on the Constitution of England had anything to say regarding 
the Cabinet. To the present day the Cabinet has never received legal recognition, yet it is the very pivot of government. Its history, therefore, deserves to be told at some length.

The Two Forms of the Cabinet.-An English Cabinet may be defined as a small council of Ministers, not known to the law, yet controlling the government. At different periods of our history such a council has been formed in different ways. In the seventeenth century it was formed by the monarch selecting those persons in whom he had peculiar confidence. In the eighteenth century it came to be formed of those persons who had the confidence of the majority of the House of Commons. In its first form the Cabinet was the creature of the king; in its second form the Cabinet is the creature of the Parliament. The transition from the first to the second form of the Cabinet was brought about by the Revolution.

The Early Form of the Cabinet.-A Cabinet in this form dates from the beginning of the seventeenth century. The word Cabinet is found in Lord Bacon's Essays. The Privy Council, we have seen, became too large for the work which it was expected to do. Many privy councillors had neither the industry, nor the knowledge, nor the ability required for taking an active part in the government. From the accession of the Stuarts onwards it had been more and more the practice of our kings to discuss affairs of state with a few men who either held some great office, or were highly considered for their talent or experience, or happened to be royal favourites at the time. What had been agreed upon in this smaller body would be formally resolved in the larger Privy Council.

Unpopularity of the Cabinet in its Original Form.The law had never recognised the existence of a smaller body within the Privy Council. The general public did not know who were its members; it was therefore regarded as unconstitutional. It was regarded as the instrument for forming and executing designs which could not bear the criticism of upright independent 
statesmen, and for which no prudent person would be responsible. A king who wanted honest advice would never consult with a mere clique in the Privy Council. All the privy councillors were entitled to have their opinion asked, for the Privy Council was recognised by the law as the king's proper adviser. Everybody knew who were privy councillors. Although members of the Privy Council were bound to secrecy, the whole council could be called to account by Parliament if the king persevered in evil courses. But how could Parliament or the courts of justice grasp an elusive body like this secret council of the king?

Growing Frequency of Cabinet Councils.-It is in vain that any number of persons set themselves against the drift of things. The Privy Council remained incapable of governing, so recourse was still had to a body which could govern. After the Restoration an attempt was made to render the Privy Council less cumbrous and more useful. It was divided into committees for the care of different departments of State, such as the Committee for Trade and Plantations and the Committee for Foreign Affairs. This expedient is not yet obsolete, but questions of general policy requiring unity of power could not be treated thus. On such questions Charles II. still took counsel with a few persons. Clarendon, Ormond, Southampton, and Nicholas formed a sort of Ministry in the first years of his reign. After the fall of Clarendon, he settled everything of consequence with the five councillors so often denounced as the Cabal. Their unpopularity suggested to Sir William Temple the need for a further reform of the Privy Council. He proposed to form a new council of thirty members, all men of independent fortune. One half were to be servants of the Crown, the other half were to be disengaged from that service. But the reformed Privy Council was still too large and too discordant to be of any use ; it speedily broke up. Charles reverted to his old practice of secret councils. James II. followed the same method. 
After the Revolution William III. ignored the Privy Council, and settled his policy with the help of a few trusty advisers. The clause in the Act of Settlement requiring that the Privy Council should transact all the business which had formerly belonged to it remained a dead letter.

The Later Form of the Cabinet.-As yet the Cabinet was not regularly composed of members of the party which had the majority in the House of Commons. The tradition that the king chose his own advisers had not lost its force. He was not yet required to take them all from the party which happened to be strongest. It was enough if none of his advisers were so much disliked by the majority in the House of Commons as to run the risk of impeachment. It was not necessary that all should positively enjoy the confidence of that majority, for it was still the accepted principle that the king was to govern, and that the Commons had only to prevent him from misgoverning. But the Revolution of 1688 made it impossible to adhere to this principle. The Revolution brought about a state of affairs in which no government was possible without the active and incessant co-operation of the Commons. In order to obtain this co-operation the king was obliged to choose for Ministers those statesmen who had the confidence of the Commons, or, in other words, who held the opinions of the majority in that House.

William III. struggled for some time against this conclusion. He wished to be king of the whole nation, not the chief of a party. He began by taking the fittest men for Ministers, irrespective of their opinions. But he found by experience that a Ministry thus composed was weak in itself, and could not hope for fair play in Parliament.

Lord Sunderland, a statesman of great experience and subtlety, showed him that he would have less trouble in governing if all his Ministers were of the party prevailing in the Commons. Between 1693 and 1696 he gradually 
formed a Ministry of Whigs. But when the Whigs lost their majority in the House, he was again at a disadvantage; for a Tory Ministry could not enter into his plans as the Whigs had done.

When William III. died, Marlborough carried on his policy. Marlborough, who had always been a Tory, tried at first to govern with the help of his own party. Finding them indifferent or hostile to the war with France, he was led gradually to replace them with Whigs. In I 708 the whole Ministry was Whig. Two years later the Tories won at the general election. The Whig Ministry was displaced and a Tory Ministry succeeded. After Anne's death another change of fortune came. The Ministers of George I. were all Whigs.

Thus, by degrees, with no fixed design on the part of any one, and simply as a matter of convenience, grew up the practice of choosing Ministers solely from the party which was strongest in the House of Commons. Once this practice was established, it led to remarkable consequences. Formerly all that was expected of Ministers was that they should be loyal to the king. Now they were expected to be loyal to their party, and consequently to each other. In form they still were, they still are, the servants and counsellors of the Crown. In fact, they became, and have continued ever since, the servants and advisers of the majority in the House of Commons.

As the king was prevented by his position from making common cause with either party, party government could not be complete until the king was practically deprived of his share in governing. This process was assisted by an accident: George I. could not speak English. He therefore thought it useless to preside at the meetings of the Cabinet. He was the first king of England who stayed away from these meetings. Thus he gave rise to the custom, now firmly established, that the Cabinet consults together apart from the sovereign. But when once the sovereign had ceased to preside in the Cabinet, it was natural to seek some other president. The person natu- 
rally chosen was the Minister most respected by the party. The leader of the party thus tended to become a Prime Minister; this term was long unpopular in England. A Prime Minister was long regarded as an ambitious subject who stood between the people and their sovereign. The name was anxiously disavowed by Ministers who really exercised the power of Prime Minister. It was not used in any official document until the Congress of Berlin in the year 1878 .

The Prime Minister.-Under the modern constitution of England, the Prime Minister is the most powerful man in the State. His functions have never been defined by statute, but they have been accurately defined by custom. They are principally three-to exercise a general control over the whole executive government; to be the organ of communication between the Cabinet and the sovereign, and to be the organ of communication between the Cabinet and Parliament.

I. The Prime Minister as Controlling the Executive.The Prime Minister may or may not take charge of some special department. One Prime Minister has been Secretary of State for Foreign Affairs, another has been Chancellor of the Exchequer. Others have held some office without any serious duties, usually that of First Lord of the Treasury. What office a Prime Minister shall hold is a matter for his personal preference, but every Prime Minister exercises a general control over all the departments. This control does not extend to the details of administration, which the head of each department settles for himself; but, whenever a question of policy has to be decided, the head of the department is bound to inform the Prime Minister and to defer to his opinion. This is particularly necessary when a proposed charge would affect the public expenditure. For the Prime Minister arbitrates, as it were, between the demands of different departments on the public purse. The Prime Minister is also expected to bestow particular attention upon foreign affairs. Every important despatch received or written by the Secre- 
tary for Foreign Affairs must be submitted to the Prime Minister.

II. The Prime Minister as the Organ of Communication between the Cabinet and the Sovereign.-The second function of the Prime Minister is to inform the sovereign of the feelings and opinions of the Cabinet, and the Cabinet of the feelings and opinions of the sovereign. None of his colleagues is allowed to meddle in this business. The sovereign, it is true, often communicates directly with the head of a particular department in order to obtain official information; but it is considered unconstitutional for the sovereign thus to communicate with the head of a department upon any question of general policy, or upon the action of the government as a whole. Such communications, if continued, would lead to the Prime Minister's insisting upon the resignation of his colleague or else sending in his own resignation.

III. The Prime Minister as the Organ of Communication between the Cabinet and the Parliament.-The position of the Prime Minister with reference to Parliament is similar to his position with reference to the Crown. All communications to Parliament concerning the feelings or opinions of the Cabinet must be made either by the Prime Minister in person or with his knowledge and approval. Mere official information may be given by the head of a particular department to the House of which he is a member. The Prime Minister usually holds the important although ill-defined position of leader of that House in which he sits, and thus enjoys by custom certain privileges in making statements to that House.

Relation of the Prime Minister to the Individual Members of his Cabinet.-The relation of the Prime minister to individual members of his Cabinet is very difficult to define. The Prime Minister is intrusted by the sovereign with the duty of choosing his colleagues. In the performance of this duty he may use his discretion, limited only by the necessity of choosing the men of the greatest ability and influence in his party. It is true that 
the limitation thus imposed is very narrow. When the Prime Minister has chosen his colleagues, he is bound to discuss with them every question of general importance. If any one of them disagrees with the Prime Minister and the rest of the Cabinet, he must either resign his office or stifle his dissatisfaction and act loyally with his colleagues in carrying out their opinion. The same rule holds where several members of the Cabinet disagree with the Prime Minister and the rest. For, by the usage of the Constitution, the Prime Minister is entitled to go on governing as long as he can command a majority in the House of Commons. Colleagues who disapprove of his conduct may resign, and when they have resigned may do their best to defeat him in that House. If they are influential, they will probably succeed in this attempt, and so force him to resign; but constitutional usage requires them so long as they remain in the Cabinet to support him loyally, and to refrain from prejudicing either the sovereign or the Parliament against him.

Deliberations of the Cabinet.-The members of the Cabinet are always members of the Privy Council. As privy councillors they are sworn not to disclose anything said in the discussion of affairs of State. No minutes are taken of the proceedings in a Cabinet Council, but it is known that these proceedings are quite informal; they are not like the proceedings of Parliament. It is not usual to make set speeches. It is most unusual to press matters to a division. The object of everybody present is to find out the general drift of opinion, and to adapt himself to that. The final resolution is accepted as the resolution of every member of the Cabinet. The Prime Minister, if able and energetic, usually dominates in these discussions.

The Working of the Cabinet System. - It is the peculiarity of the Cabinet system, as above described, to combine much of the unity, secrecy, and promptitude which belong to a despotic monarchy, with complete dependence upon the goodwill of a large representative 
assembly. Such dependence would make government impossible were that assembly a mere loose, unconnected gathering of individuals or of small knots of men. But the House of Commons has very rarely fallen into that condition; it has usually been divided into two great parties, each of which is firmly bound together by tradition, by opinion, by interest, and by strict organization. The ordinary member will go far indeed before he deserts his party, and the party will go far before it deserts a leader whose ability, experience, and reputation it has found highly advantageous. These circumstances make tolerable the dependence of the Cabinet upon the House of Commons. The Cabinet system is essentially based upon the party system. Cabinet government is thus open to the grave objection of undergoing a change of policy whenever a party which has previously been in a minority acquires a majority. This objection would be fatal if the two great parties did not agree in many of the most fundamental ideas of government. If they differed like Catholics and Protestants in the sixteenth, or like Cavaliers and Roundheads in the seventeenth century, party government would involve everlasting revolution. The Cabinet system, therefore, cannot work well except in a country where political differences are restricted and political passions are under control.

Ministerial Responsibility under the Cabinet System. - Under the Cabinet system ministerial responsibility assumed a new form. So long as Ministers were really appointed and dismissed by the king, it was only by means of impeachment that the House of Commons could drive a Minister from office. Thus, in order to get rid of a Minister whose policy they condemned, the Commons had recourse to a criminal accusation, and, in order to carry their point, often wrested the law, especially the law of treason, in the most arbitrary and shameful manner; but from the time when difference of opinion between the Minister and the majority of the Commons resulted, as a matter of course, in the resignation of the Minister, im- 
peachment was confined to its proper use as a means of bringing actual law-breakers to justice. A fallen Minister had no longer any reason to fear the loss of his life or estate, and even young members of the House of Cornmons ceased to threaten the king's advisers with the axe and block.

Final Prevalence of the Cabinet System.-The Cabinet system, as above described, was not completed until the nineteenth century. But it was established in all important points in the course of the reigns of George I. and George II. Sir Robert Walpole was, perhaps, the first Prime Minister in the modern sense of that term. During his long term of office, from I72I to I742, he asserted his right to be the mouthpiece of the Ministry in Parliament and in the royal closet. He enforced strict subordination on the part of every colleague. Any one who tried to exercise the independence formerly enjoyed by Ministers and privy councillors was promptly dismissed from office.

Reaction against the Cabinet System. - Walpole anxiously disclaimed the title of Prime Minister, which he knew to be hateful to the English people, but his unquestionable supremacy provoked a violent reaction. Both Whig and Tory had reason to dislike the Cabinet system. Proud of their birth, their wealth, their hereditary influence in the State, the Whig chiefs were naturally averse to a system which merged all their wills in the will of one ambitious member of the House of Commons. Taught by tradition that the king was the real, not merely the nominal, head of the State, the Tories were instinctively hostile to a system which reduced the royal authority to a shadow. Yet they might have acquiesced in a diminution of the power of a Hanoverian king if it had not been accompanied by their entire and permanent exclusion from office. As it was, the Tories who wished to be Ministers united with the Whigs who had been driven out of the Ministry. Lord Bolingbroke expounded the constitutional theory of the opposition in his famous 
treatise, "The Patriot King." The patriot king was to revive the tradition of the English monarchy, to disregard party, and to select wherever he could find them those Ministers who were willing to work under him for the common good.

The Opposition at length succeeded in driving Walpole from office. But they did not seriously endeavour to give effect to the doctrines of Bolingbroke. After some years of weakness and confusion caused by jarring ambitions, events renewed their natural course, and the Cabinet system was restored.

Changes in the Great Offices of State.-With the decline of the power of the Privy Council the office of Lord President lost its consequence. It is now virtually a sinecure, bestowed upon some public man who is valuable as a member of the Cabinet, but who cannot undertake serious ministerial duties.

In this period, also, the office of Lord Treasurer became obsolete. The last Lord Treasurer was the Duke of Shrewsbury, appointed by Queen Anne on her deathbed. On his resignation in October of the same year, the Treasury was put into commission. It has so continued ever since. But the commissioners take scarcely any part in the management of the finances. The office of First Lord of the Treasury is usually held by the Prime Minister, because it is dignified and does not involve any labour. The junior Lords of the Treasury are chiefly employed in other than financial business. The real control of the finances is centred in the Chancellor of the Exchequer. The office of Chancellor of the Exchequer dates from the reign of Henry III., but his importance as a Minister dates from the reign of George I. The Chancellor of the Exchequer had always been a commoner. Since the Treasury was put in commission he has invariably sat in the House of Commons. 


\section{CHAPTER XII.}

GEORGE III., 1760-1820.

Introduction.-The reign of George III. occupies the interval between the period of Whig supremacy and the period of democratic change. Its constitutional interest is twofold. The first part of the reign was taken up with the king's efforts to arrest the progress of parliamentary government, to interfere with the new Cabinet system, and to make the royal authority once more real. The second part of the reign was not marked by any great event in constitutional history, save the Union with Ireland; but it was a time of preparation for constitutional changes of the gravest moment. The foundation of the American Republic, the outbreak of the French Revolution, the suffering incidental to the great war with France, and above all the wonderful expansion of English commerce and industry, due to a series of brilliant mechanical inventions, changed at once the structure of English society and the character of English politics. Suppressed for the moment, the forces of revolution accumulated until after the close of the war with France and the death of George III. ; then they broke out with redoubled power.

Accession of George III.-Fall of the Whigs.-The young king was not a remarkably able man, but he was laborious, resolute, and despotic in temper. His father, Frederick, Prince of Wales, had died whilst he was yet a child. The Princess, his mother, had taught him high notions of prerogative. "George, be king," was her repeated exhortation. George was, therefore, prepared 
to claim more authority than had been wielded by the two first kings of his house. He would not be content with that division of power which gave the substance to the Whig aristocracy and the shadow to the Hanoverian king. Nor was he dependent upon the Whigs as George I. and even George II. had been. George III. was born and brought up in England; he could say in his first speech to a new Parliament that he gloried in the name of Briton. He was popular with the mass of his subjects; he was especially popular with the Tories. The great majority of the Tories had never been earnest Jacobites. After the failure of the rebellion of I745, the Jacobite party was virtually extinct. The Tories could therefore indulge their natural disposition to support the royal prerogative by rallying round the young king.

The Whigs were suffering from the ill effects of too much prosperity. Under George I. and George II. they had been so secure of power that they could afford to quarrel among themselves. They were now broken up into a number of small factions, representing rather this or that great family than any great principle. The elder Pitt indeed had lifted English politics to a higher level; he had appealed with success to the English nation. He was now Secretary of State and virtual Prime Minister. He had raised England as high as she had been raised by Marlborough. But George III. had an instinctive dislike of genius, and was resolved to tolerate no independent will in the government. His first step was to rid himself of Pitt. He drew up his first speech to Parliament without consulting the Secretary of State, then he took advantage of the jealousy which Pitt inspired in the other Ministers. Pitt had resolved to declare war against Spain, which was preparing to unite with France against Great Britain. His colleagues shrank from taking so bold a step; the king supported them, and Pitt was forced to resign. The king bestowed a pension on Pitt and the rank of baroness on his wife; but this show of kindness only served to lessen Pitt's 
popularity. Lord Bute then became Secretary of State and virtual Prime Minister. Supported by the king, he did all that he could to annoy his colleagues and make them feel that they were powerless. The first Lord of the Treasury, the Duke of Newcastle, who represented the great Revolution families, was forced to resign soon after Pitt had retired. Then Lord Bute became Prime Minister. He immediately began to negotiate for a peace with France. All who ventured to express disapproval of the preliminaries were made to feel the king's displeasure. Not only privy councillors and lords-lieutenant, but many humble public servants were dismissed for this offence.

The King's Friends. - Lord Bute had neither the ability nor the resolution necessary to carry out the unconstitutional policy of the king. $\mathrm{He}$ was soon driven from office; but the king was still resolved to be master. $\mathrm{He}$ had recourse to one statesman after another. He generally failed to obtain that unbounded submission which he required. But whenever his Ministers attempted to act upon their own judgment, they found themselves harassed. and baffled by his intrigues. The confidence which he refused to them he bestowed on other politicians who were not responsible to Parliament. These men would cast their votes, not for the policy of the Ministry, but for the policy favoured by the king. They would inform the other members of Parliament that the king disapproved of the measures of his Ministry. They would canvass against the Ministers, and use promises and threats to stimulate opposition. These men were known as "the king's friends."

The Cabinet System Attacked.-The King's object at this period of his reign was to regain that effective control of the government which had been enjoyed by the kings who reigned before the Revolution. He wished to choose his Ministers, to dictate the policy of his Ministers, and to get rid of them when they ceased to comply with his wishes. But he thus came into conflict with the 
new system of Cabinet government described in the last chapter, under which Ministers are really chosen by the majority of the House of Commons to carry out its will, and lose office only when they lose their majority. This new system was so well suited to the political condition of England that it had already struck deep root. George III. could not abolish it, or even permanently arrest its growth. He could only impede its easy natural working by underhand and often discreditable means. Even this much he could effect only by influencing the House of Commons. Thus he was obliged, even whilst attacking parliamentary government, to employ parliamentary weapons.

The House of Commons and the Infliuence of the Crown.-As the Cabinet system is based on the supremacy of the House of Commons, the House might have been expected to unite in its defence; but so far from the king encountering unanimous resistance, he usually secured a majority in the Commons. For this there were several reasons.

I. The Cabinet System was still New.-The Cabinet system had not yet become familiar to the public. It was an unavowed system. The language of lawyers, tradition, and sentiment ignored the Cabinet and pointed to the king as the head of the executive government. The Tories accepted Bolingbroke's theory of a patriot king employing men of merit irrespective of party. The Whigs had no clear notion of the extent of the change which they had effected.

II. Indifference of the Mass of the People.-The mass of the people, outside London and one or two other large towns, cared little for the issue of the conflict between the king and the Whigs. The Whigs, whilst almost republican in their ideas, were an aristocratic party. They had not much hold upon the lower classes. Pitt had once swayed the body of the people, but Pitt was not, in any sense, the leader of the Whigs.

III. Parliamentary Corruption.-In the absence of any general hostility to his plans, King George could do much 
by seducing or intimidating individual members of the House of Commons. The art of corruption was no new thing. It had been practised by kings and Ministers ever since the Restoration. During the hundred years preceding the accession of George III., the House of Commons had obtained the control over public affairs without being made fully responsible to the nation. Its debates and divisions were kept secret. Many of its members sat for boroughs with a merely nominal constituency. As the House was not controlled by public opinion, it could be controlled only by corruption. After the Revolution of 1688 , the temptation to corrupt members of the House of Commons became still stronger. Walpole gained, perhaps unjustly, the reputation of having perfected corruption. George III. was not inferior to Walpole. He spent so much in bribery, that, notwithstanding his large civil list and his strict economy, he ran deeply into debt. He used intimidation as well as bribery. He treated every important. division as a personal matter, causing his wishes to be made known to members, scrutinising the division lists and distributing favours or punishments accordingly. In I 764 General Conway and other officers of the army were deprived of their commissions for voting contrary to the king's wishes.

IV. State of Parliamentary Representation.-Parliamentary representation had been deeply vitiated by the combined influence of the causes so often referred to alreadythe original disproportion between the representatives of counties and the representatives of boroughs, the creation of numerous rotten boroughs by the Tudors and Stuarts, the decay of many ancient towns returning members; and owing to these causes a great number of seats were absolutely at the disposal of the Crown, and a still greater number were virtually the property of private persons. Some powerful families could return six, eight, or even ten members. Probably one-third of the House of Commons was thus nominated by private individuals or by the Crown. As the House of Commons 
was now supreme, great prices were paid for boroughs by wealthy men, who did not really care about politics, but who wished to get consideration. These men, when returned to the House, commonly voted with the Court, because it was the fashionable side. Besides the nomination boroughs, there were a number of boroughs still retaining some independence, in which the electors were few and corrupt. These electors sold their votes as a matter of course. The Government candidates were sure to succeed if supplied with the means of bribery. Under these circumstances the Government was almost always successful in managing the House of Commons. The long persecution of John Wilkes showed that the majority of the Commons were ready to support the king to all lengths.

Case of John Wilkes.-John Wilkes was a clever dissolute man and an extreme Whig. He was member for Aylesbury and proprietor of a paper called the North Briton, which he used to attack Lord Bute. In No. 45, written after Lord Bute had resigned, he attacked the king's speech expressing approval of the peace with France. He was arrested on a charge of libel. This was illegal, for a member of Parliament could not be arrested on any other charge than one of treason, felony, or breach of the peace. Moreover, he had been arrested by a general warrant, that is, a warrant indicating no particular person, but directing the arrest of the authors, printers, and publishers of his paper. Warrants of this kind would render many persons liable to arrest although they might have nothing whatever to do with the offence alleged. Such warrants were declared to be illegal by the Court of King's Bench in I765. In I766 they were condemned by a resolution of the House of Commons, passed under the influence of a Whig Ministry, which then happened to be in office.

In 1763 the House of Commons would not wait for the judgment of a court on the charge of libel, but voted that No. 45 of the North Briton was a seditious libel, ordered it to be burned by the hangman, and expelled Wilkes 
from the House. The people, at least in London, were on the side of Wilkes, for they thought that he had been hardly treated. But Wilkes did not venture to await his trial when the Government and the House of Commons were so incensed against him. He fled from England, and thus incurred sentence of outlawry by failing to stand his trial for libel. A few years later he returned to England and was elected member for Middlesex. He was expelled for having published a libel on Lord Weymouth, then Secretary of State. When he was re-elected by the county of Middlesex, the Commons pronounced that he was disqualified, and that his opponent, Colonel Luttrell, had been duly returned. This was unconstitutional, as the House is not entitled to elect its own members.

Publication of Parliamentary Debates.-In spite of its arbitrary temper, the House of Commons had to submit to an innovation which has enormously increased the power of public opinion over the action of Parliament. This was the publication of debates. In early times the House of Commons had done all in its power to keep the debates secret. It was justified in so doing. Without secrecy a member could not be safe in speaking his mind. Even with the utmost care to maintain secrecy, servile members often betrayed enough to bring down the royal displeasure upon those who expressed themselves too freely. Thus it became a standing request of the Commons to the king that he would pay no heed to any reports of their proceedings made without the authority of the House. Any person making such a report was treated as an offender against the privileges of the House.

But after the invention of printing, and the changes which augmented the power of the House of Commons, other persons than the king. and his Ministers became curious to know what passed in debate. The leaders of the Long Parliament saw their advantage in this curiosity. In I64I the Parliament allowed its proceedings to be published, but publication without leave continued to be treated as a violation of privilege. Thus, from the 
Revolution onwards, there was perpetual conflict between the wishes of Parliament and the wishes of the public. Debates were reported, but at the reporter's risk, and under difficulties which made the report imperfect and partial. As no shorthand writers were admitted to the House, there could be no accurate record of the speeches. Recollections more or less inexact, and always tinged by party feeling, afforded the only material for the published accounts of what was said. The imperfection and injustice of the reports afforded a new argument against allowing any debates to be printed.

But in the year I77 I Wilkes incited certain rewspapers to publish the speeches delivered in the House of Commons, together with the names of the speakers. The House ordered the printers to be taken into custody. The printers treated the order with contempt, whereupon the House requested the king to issue a proclamation for their arrest. But when Miller and Wheble, two of the persons named in the proclamation, were arrested, Wilkes, as an alderman of the City, and the Lord Mayor, refused to recognise the arrest as legal, since no offence against the law was specified in the proclamation. They released the prisoners accordingly. As they were both members of the House, they were themselves ordered to attend in their places, and were sent to the Tower. But such was the enthusiasm shown in their favour by the Opposition and the city of London, that the House thought it better to drop the subject. From that time onwards no objection has been raised to any fair report of speeches delivered in the House. The reporters remained, however, on the footing of other strangers present at the debates, and were liable to be excluded on the motion of any member. To take notes in the House was still contrary to rules, so that the reports were necessarily imperfect. It was not until the burning of the old Houses of Parliament in I 834 that a separate gallery was provided for reporters. Although the House of Commons alone had been concerned in the quarrel with the printers, the freedom of 
reporting was established at the same time for the House of Lords; but it was not until I836 that the division lists of the House of Commons, and not until I 857 that the division lists of the House of Lords, were regularly published.

The freedom of reporting parliamentary debates ranks only second to the reform of parliamentary representation in constitutional importance. By the publication of parliamentary debates and divisions, all who can read a newspaper have been made partakers in political discussion. Political knowledge and an interest in politics have been diffused far more widely than in any former period. The power of the House of Commons has been reduced, and the power of the press has been increased. Newspapers became more attractive when they began to give full reports of proceedings in Parliament. Having more ample material for criticism, they could criticise with more effect.

Fox's Libel Act, 1792.-The freedom, and therefore the force, of political discussion in newspapers was increased by an Act of Parliament passed many years after the liberty of reporting had been established. Since the lapse of the censorship of the press, writers had been free to publish what they pleased, subject, however, to punishment if they offended against the law of libel. But the definition of libel was extremely elastic. What the Opposition might consider fair criticism the Government might consider a seditious libel. The freedom and safety of political writers depended largely on the nature of the authority charged with deciding whether certain expressions were or were not libellous. It had been repeatedly laid down that upon a prosecution for libel the jury had nothing to do beyond deciding on the fact of publication by the accused. Whether the publication was libellous was to be decided by the judge. The judge, as a rule, was prepossessed in favour of the Crown. This rule therefore operated to the injury of political writers. The rule was attacked by Erskine, the celebrated advocate, and was abolished by Fox's Libel Act. This Act pro- 
vided that the question whether a particular publication is libellous shall be decided by the jury. Its effect has been entire freedom of political discussion. Not only fair criticism, but also unmeasured abuse of the Government is perfectly safe, so long as the writer does not incite to a breach of the law.

The American War.-The king had never relaxed in his efforts to obtain control of the government. In Lord North he at last found such a Prime Minister as he required. Lord North was an able man, personally honest, and remarkably good-natured, but altogether wanting in moral courage. The king and former Ministers had involved England in a dispute with the North American colonies by taxing them without their consent. The king hardened himself against any concession for the sake of peace, and endeavoured to subdue the colonists by force of arms. Lord North made himself the instrument of this policy, which he did not approve. The French came to the assistance of the colonists, and we were defeated. The nation became weary of the war, the Opposition redoubled their attacks, and Lord North was driven from office. Thus the king's obstinacy in refusing to make terms with the revolted colonies had brought about a disaster which left him at the mercy of his old enemies, the Whigs.

Renewed Conflicts of the King with his Ministers. Upon Lord North's retirement Lord Rockingham formed a Whig Ministry, but he died within a year and his Cabinet broke up. The more decided Whigs, led by Charles Fox, withdrew from office. A new Ministry was formed by Lord Shelburne, an able statesman, who could hardly be said to belong to either party, and was distrusted by both. Had the Whigs wisely waited their time, they might have regained their former supremacy. But their leader, Fox, impatient for power, formed a coalition with Lord North, whom he had until lately denounced in the most savage terms. The allies forced Lord Shelburne to resign, and formed the famous Coalition Ministry. Their unscrupulous ambition, however, disgusted the nation. Their Bill for the better 
government of India aroused the furious anger of the king, who saw in some of its provisions an attack on the prerogative of the Crown. He could not arrest the progress of the Bill in the Commons, but resolved to defeat it in the Lords. He authorised Earl Temple to inform the peers that he should regard as an enemy every one who voted for the India Bill. The Lords threw out the Bill, and the king dismissed Fox and North.

The King in Conflict with the House of Commons.Fox and North commanded a powerful majority in the House of Commons. They felt sure that they could drive from office any Minister whom the king could find. The king showed unusual sagacity in choosing William Pitt, the second son of the great Lord Chatham, then only twenty-five years of age. Pitt waited a few months for a favourable opportunity to dissolve Parliament. During this time he carried on the government in defiance of the will of the majority of the House of Commons. This course was coming to be regarded as unconstitutional, and has only once been followed in later times. But the Opposition made the grave mistake of showing that they feared the result of an appeal to the country. The general election of I784 gave Pitt a friendly House of Commons. This election marks the final overthrow of the Whig party as it had existed since the Revolution of 1688. With two short intervals, the Whigs were excluded from office for forty-six years. They regained power only after a complete change in the political and social condition of England.

The King's Influence in the Latter Part of his Reign. -The king had defeated the Whigs, but he had defeated them only by the help of a man very different from North or Bute. Pitt would not submit to dictation, and the king dared not dictate to the Minister who had saved him. On one occasion, indeed, Pitt found the king immovable. In order to effect the parliamentary union of England and Ireland, Pitt held out a hope that Catholics would be admitted to Parliament. When he attempted 
to fulfil his undertaking, the king would not hear of Catholic emancipation. Pitt resigned, but presently returned to office, and fearing to unsettle the king's reason, pressed the subject no further. After Pitt's death the king tried to extort from the Grenville Ministry in 1807 a promise never to raise the question of admitting Catholics to Parliament. Their refusal to give this pledge resulted in their loss of office. But the king's insanity prevented him in his last years from taking any continuous part in politics.

Growing Demand for Parliamentary Reform.-The Whigs had been taught by their discomfiture at the hands of the king the necessity for a fuller representation of the people in Parliament. Both Chatham and Wilkes had demanded a reform in parliamentary representation. The younger Pitt introduced a Reform Bill soon after taking office. He proposed to take one hundred members from small boroughs, and to distribute them among the counties and the great towns. He was willing, however, to compensate the owners of the pocket-boroughs which were to be suppressed. The king did not venture openly to oppose so modest a reform, but he tried to discourage Pitt. Pitt's followers were hostile and rejected his Bill. Occasional motions were afterwards made in favour of parliamentary reform, but its opponents were enabled by the reaction from the excesses of the French Revolution to defeat them all.

Progress of Religious Liberty.-The spirit of religious intolerance, which had been so strong in the seventeenth century, had lost force in the eighteenth century. The old controversies between Catholic and Protestant, between Churchman and Nonconformist, had lost their attraction for the public. Since the accession of the House of Hanover the Nonconformists had enjoyed practical toleration. The last persecuting laws directed against Catholics had been passed in the reign of George I. Yet there was left enough bigotry among the mass of the people to make their repeal dangerous. Sir George 
Savile's Act of 1778 allowed Roman Catholics to acquire land, and abolished the penalty of imprisonment for life imposed on a Catholic priest who dared to celebrate the rites of his Church. The consequence of this Act was the celebrated Gordon Riots of 1780 . Toleration, however, continued to make progress. By I793 Roman Catholics and Dissenters had been freed from all restraint upon worship, education, or the acquisition of property. All further progress was then stopped by the reaction against the French Revolution.

The Parliamentary Union of Great Britain and Ireland.-The parliamentary union of Great Britain and Ireland was effected in I 800 . Until the year I 782 the Irish Parliament had been kept in strict subordination. An Irish statute passed by Sir Edward Poynings, Lord Deputy of Ireland under Henry VII., forbade the consideration of any measure other than a money Bill which had not first been approved in the English Privy Council. An English statute of the reign of George I. asserted the right of the Parliament of Great Britain to make laws for Ireland. Henry Grattan, supported by the Irish Volunteers, took advantage of the unfortunate war with the American colonies to demand the repeal of these statutes. They were repealed in 1782 , under the Rockingham Administration. The Irish Parliament was thus recognised as possessing full legislative powers. Nevertheless, Ireland could not be said to have gained national independence. In the first place, the right to vote in the election of members and to sit in Parliament was confined to Protestants. In the second place, a majority of seats in the Irish House of Commons was at the disposal of the Crown, or of great families which were all Protestant. Lastly, the real heads of the executive government, the Lord-Lieutenant and his Chief Secretary, depended for power, not on the Irish Parliament, but on the Crown - that is to say, on the English Ministry for the time being. Thus the influence of England upon Irish affairs continued to be very great. 
For several years the relation between the two kingdoms underwent no change. The Irish Parliament pur-sued a more liberal policy than of old towards the Catholics. It repealed the laws which interfered with their freedom of worship, with their education, and with their right to acquire landed property. It gave them the franchise, although it withheld the right to be elected. But the Catholics remained in a very unsatisfactory condition. They formed the great bulk of the inhabitants of Ireland; they were, in fact, the old Irish nation as opposed to the English and Scotch settlers. Yet successive confiscations had deprived them of nine-tenths of the land. They were excluded from place and power, from either House of Parliament, and from the municipal corporations. They had to pay tithe for the support of the Established Church, which they regarded as heretical. They had till lately been subjected to the cruel penal laws which excluded them from all the professions, and made the remnant of their property insecure. It was inevitable that the majority of the Irish Catholics should be hostile to the Protestants and to England. If the Protestant ascendency were broken down, and the Catholics were allowed their natural share of power, it was certain that the Irish Parliament would no longer work in any tolerable harmony with the British Parliament. Yet the Protestant ascendency was naturally breaking down under the influence of modern ideas of freedom and toleration. Many of the Protestants, led by Grattan, were anxious to mitigate that ascendency. Pitt, like all the best English statesmen of the time, wished to improve the position of the Catholics. The time was coming when the Irish Parliament would no longer be controlled by the Crown and the Protestant aristocracy. What link would then be left between the two kingdoms?

The outbreak of the French Revolution brought on a crisis in Irish politics. French ideas of freedom became popular in Ireland. An attempt was made to unite the Irish Nonconformists with the Irish Catholics in the effort 
to establish an Irish Republic, organised on democratic principles, and altogether independent of Great Britain. This movement ended in the rebellion of 1798 . Most of the Irish Nonconformists had withdrawn from the movement sooner than accept aid from France. Thus the rebellion of 1798 was essentially similar to the risings of I64I and I688. It was a revolt of the Irish Catholics against the Protestant conquerors. After it had been suppressed, Pitt resolved to end at once the Protestant ascendency and the legislative independence of Ireland. The Irish Parliament was induced, probably with the help of corruption, to pass an Act ending its own existence.

By the terms of the Union, Ireland was to send a hundred members to the House of Commons, and four spiritual and twenty-eight temporal peers to the House of Lords. The temporal peers were to be elected by the whole body of Irish peers and to hold their seats for life. Ireland retained her separate Established Church. The law of Ireland being substantially similar to the law of England, no general safeguard of its validity was necessary. Complete freedom of trade was established between England and Ireland. Pitt wished to enable Catholics to sit in Parliament, and thus to reconcile the mass of the Irish people to the Union. He was baffled by the obstinacy of George III. Catholic emancipation was not secured until twenty-eight years later, and only after a struggle which revived the ancient antipathy of the Catholic Irish to England.

Development of Democratic Ideas.-More momentous than any legislative changes were the new social and political influences which began to be felt in the reign of George III. From that time dates the growth of modern democratic ideas. These ideas have not been peculiar to any one nation; they have been the common property of the peoples of Europe. Their progress was partly due to general causes which cannot be stated here, but it was also due in part to causes of a more definite kind. These were (I) the influence of the great French writers 
of the eighteenth century ; (2) the foundation of the Republic of the United States; (3) the outbreak of the French Revolution; (4) the industrial revolution in England. It is necessary to know something about the operation of these causes, if we would understand the course of English constitutional history in the nineteenth century.

I. The Infuence of the Great French Writers of the Eighteenth Century.-In their discussion of political and social questions the French writers of the eighteenth century were at first influenced by admiration of England. The study of English institutions was just coming into fashion. Until the Revolution of 1688, and for some time afterwards, English institutions had awakened scarcely any interest abroad, and were almost unknown to foreigners. Attention was first called to them by the rapid rise of England in the years following the Revolution. The wars of William III. and Anne broke the strength of France and made England the first power in Europe. The prosperity of the English people appeared more remarkable in comparison with the wretched state of other nations, especially of the French. The French, our unsuccessful rivals and our nearest neighbours, were most forcibly struck by the contrast. For the first time Frenchmen began to examine English society. They saw that Englishmen possessed a political, religious, and industrial freedom unknown in France. Thus they were led to the natural, although exaggerated conclusion, that the greatness of England was entirely due to her liberty.

The love of liberty in France was thus kindled by the study of English institutions. But the French writers soon carried the demand for liberty far beyond English precedents. The French temperament is hotter than the English. The lack of political experience and the hatred excited by misgovernment in France hindered Frenchmen from seeing that liberty alone is not a cure for all the evils of our lot. French political economists began to build economic theories on the assumption that Nature: 
left to herself, will ensure the greatest production and best distribution of wealth. All legislative interference with commerce and industry, they said, is mischievous. Rousseau, a Frenchman by adoption, although a Genevese by birth, went so far as to teach that all the misery of man is due to civilisation. The savage man was good, wise, and happy. Together with all existing civilisation he condemned all existing governments. Even the English, he said, were not free except whilst a general election was in progress. He tried to found government entirely on the consent of the governed. He took no account of the historical reasons which make different forms of government preferable in different times and countries; for he would not allow any government to be good, unless it conformed to the natural rights which he assumed every man to possess.

II. The Foundation of the United States.-The course of politics in England had been little affected by any events in foreign countries. Isolated from our neighbours by the sea, we had preserved the free institutions of the Middle Ages at a time when nearly the whole of Europe was governed by absolute monarchs. The republics of Holland and Switzerland were too small to have any influence on our political ideas. They were, moreover, aristocratic in constitution. But the foundation of the United States had a powerful effect upon the politics of the mother country. The American people were our kinsmen, only recently separated from us, and still preserving most of our laws and institutions. When they established a.democracy without a king, a nobility, or an Established Church, they revived ideas which in England had lain buried since the fall of the Commonwealth. The effect was the greater because these ideas were now detached from the peculiar religious opinions which had proved so distasteful to most Englishmen. For the founders of the American Union had studied recent French literature, especially the writings of Rousseau, and rested their new constitution upon principles supposed to be applicable 
everywhere. The liberties of the people of England had always been claimed as their peculiar inheritance, secured by custom, by charter, and by statute. The liberties of the American people were asserted to be the inalienable rights of human nature.

III. The Outbreak of the French Revolution. - The French Revolution was an attempt to carry into effect the principles preached by Rousseau and other French philosophers. It was hastened by the establishment of the United States. At first it met with sympathy from the English people, who regarded it as the means of establishing constitutional government in France. But the extravagant theories proclaimed, and the cruel deeds committed, in the course of the Revolution, alienated and disgusted most Englishmen. The French republic proved as aggressive as Lewis XIV., and forced war even upon Pitt, who honestly wished not to interfere in French affairs. The war with France lasted twenty-three years. It caused severe suffering in England; suffering bred discontent, and discontent was met with repression. Meantime the memories of the French Reign of Terror had put a stop to all liberal legislation in England. The most reasonable reform was regarded as a step towards anarchy. Nevertheless, the ultimate effect of the French Revolution was favourable to democratic opinions. The final triumph of democracy in a great country so near our own assisted the progress of democracy among ourselves. In the nineteenth century English Radicals have usually looked either to France or to the United States for inspiration.

IV. The Industrial Revolution.-The industrial revolution began in the middle of the eighteenth century. Until then the people of England had been engaged chiefly in agriculture. They produced more food than they required, and exported considerable quantities of corn. Manufactures were carried on by hand labour, chiefly in the homes of the workmen, and to a large extent in the country. The employer commonly worked 
at the trade himself, and often combined with it the cultivation of a farm. Machinery was little used; large factories were almost unknown; towns were comparatively few and small. Only in one or two large seaports, like London and Bristol, could there be found merchants and bankers equal in riches to the great landed proprietors. Land was still the basis of wealth and influence, the landowners were still the most powerful class in the kingdom.

From the middle of the eighteenth century onwards, this state of things began to change. Machinery was more and more employed in all important industries. With the rise of machinery came the establishment of factories. Production on a large scale took the place of production on a small scale; the employer had now a much greater number of workmen than formerly; he ceased to work with his own hands, and gave all his time to managing his business. The change was stimulated by the increasing use of steam as a motive power. The introduction of steam power gave a decisive superiority to the country which was richest in fuel. Thus England became the foremost manufacturing country of the world. Manufacturers and merchants began to equal or surpass the riches of the landowners; the middle class acquired such social and political consequence as it had never enjoyed before.

With the progress of manufactures, mining, and shipping, the balance of population between town and country changed more and more. The country population still grew, but grew far less rapidly than the town population, for the new conditions of industry required that producers should be collected together in great masses. Thus many large towns arose, especially in the North of England and the Lowlands of Scotland. This change also produced memorable consequences. People who live in large towns have always been more disposed to political change than people living in the country. They are more quick-witted and critical; they are less influenced by custom; they are 
more nervous and excitable. In England this difference was deepened by the fact that most of the large towns were new. They had no ancient institutions or traditions, no class of persons accustomed for centuries to lead the rest of the citizens. They naturally became centres of democratic feeling.

A few of the towns which owed their greatness to the industrial revolution had been ancient parliamentary boroughs, and so returned members to the House of Commons. But most of these towns, if they had then existed at all, had been villages, or less than villages, when the ancient system of representation had been settled, and were therefore unrepresented. Even Leeds and Manchester, although they had been places of some importance so long ago as the time of the Edwards, had no representatives. Thus a vast commercial and industrial population, abounding in talent, energy, and ambition, found that it had a smaller share in Parliament than the few great families which controlled so many pocketboroughs. It was therefore resolved to obtain parliamentary reform. Parliamentary reform may be regarded as the first political result of the industrial revolution.

A second political result of that revolution was to be municipal reform, for these rising towns had no proper system of local government. The ancient institutions of the hundred or of the parish or township, or even of the petty borough, were utterly inadequate to the wants of immense seaports and manufacturing towns. There innumerable multitudes were crowded together, without any means of providing for the most elementary wants of city life. There was no authority capable of ensuring proper pavements in the streets, proper drainage in the houses, a police sufficient to put down crime, or parks and gardens for public recreation. The districts inhabited by labourers and artisans were full of discomfort, disease, and squalor. At first individual towns tried to better their condition by obtaining special Acts of Parliament to regulate their own administration, but as time went on it was found necessary to reform municipal government throughout England. 


\section{CHAPTER XIII.}

\section{GEORGE IV., WILLIAM IV., AND VICTORIA, I $820-1888$.}

Introduction.-The period extending from the death of George III. to our own day can hardly be paralleled in English history for the number and extent of the changes made in the Constitution. Not even the period of the Norman Conquest nor the period of the Reformation can compare with it in legislative innovations. The innovations of this period all tend in the same direction; they are all steps in the passage towards democracy. The forces making for democracy had been pent up so long as the English were contending with the French for freedom and empire; but when the war with France had been ended by the victory of Waterloo, these forces began to find an outlet. They have been at work ever since upon the Constitution.

The decay of old religious animosities has left men more free to take sides according to what appears to be their material interest. The industrial revolution has withdrawn a large part of the population from the country, where custom and tradition are most powerful, to assemble them in cities, where the desire of bettering one's condition is universal. The same revolution, by collecting workmen in great masses for the production of wealth, has helped them to organise themselves for mutual assistance, for higher wages, and for political change. The general diffusion of reading and writing, the extraordinary number of newspapers, and the skill shown in organising party, have all increased the political influence of numbers. 
The progress of democratic ideas in other countries has reacted upon political opinion in England.

It is impossible, within the limits of a single chapter, to give more than the merest outline of the legislation of this period. The principal constitutional changes may be grouped under the following heads :-

I. Progress of Religious Equality.

II. Reform of Parliament.

III. Further Development of Cabinet Government and Changes in the Executive Departments.

IV. Reform of Local Administration.

I. Progress of Religious Equality.-We have seen that at the outbreak of the great war with France, Catholics and Nonconformists had been released from all legal restraint upon their worship, the education of their children, and the acquisition of property. From the outbreak of the great war to the death of George III., progress towards religious equality had been almost suspended. A few concessions had indeed been made. In I 8 I 3 Irish Catholics were enabled to hold in England any civil or military office which they might have held in Ireland previous to the union of the Parliaments. In I8I7 the Military and Naval Officers' Oaths Act admitted both Catholics and Nonconformists to all ranks in the army and navy. But the Test and Corporation Acts, which required the taking the Sacrament according to the rites of the Church of England, as a qualification for service under the Crown and municipal office, were still law, although made of no effect by the Indemnity Acts, passed to protect transgressors. The necessity of taking the oath of supremacy still more effectively excluded Catholics from municipal bodies or the public service. The necessity of making a declaration against transubstantiation and the worship of the saints excluded Catholics from sitting in either House of Parliament. Catholics had obtained the parliamentary franchise in Ireland, but were still deprived 
of it in Great Britain. Lastly, both Catholics and Nonconformists suffered much annoyance from peculiarities of the law which will be explained when we come to describe the remedial measures.

Removal of the Sacramental Test, 1828.-The repeal of the Test and Corporation Acts had been suggested from time to time, but nearly forty years had elapsed since the last of these proposals. In the reign of George IV., however, the Whigs were recovering from that impotence to which they had been reduced by the rashness of Fox and by the recoil from the French Revolution. Their leader, Lord John Russell, renewed the struggle for religious equality by moving in 1828 for a committee to consider the Test and Corporation Acts. In spite of a faint opposition offered by the Wellington Government, he carried his motion by a large majority. Soon afterwards he introduced a Bill to take away the necessity of receiving the Sacrament according to the rites of the Church of England, as a qualification for office. The Bill passed its second reading unopposed. Mr. Peel (afterwards Sir Robert Peel), the Tory leader of the House of Commons, was at heart favourable to religious freedom. He persuaded the parties most hostile to Lord John Russell's Bill to content themselves with requiring from every person about to enter upon office a declaration that he would not use the power, authority, or influence which he derived from it to the detriment of the Church as by law established. The words "on the true faith of a Christian," added to this declaration, had the effect of excluding Jews from the benefit of the Act. Nonconformists obtained by this Act free admission to municipal office, and to almost all offices in the gift of the Crown.

Act for the Removal of Catholic Disabilities, 1829. -We have seen that Pitt intended to follow up the parliamentary union of England and Ireland with the grant of full political equality to Roman Catholics, but that he was baffled by the dull obstinacy of the king. The Roman Catholics could not forget the hopes which 
had been held out to them by Pitt. The English and Scotch Catholics were too few to enforce their demand for equality, but the Irish Catholics were numerous enough to threaten insurrection. Daniel O'Connell, an Irish Catholic barrister, had set on foot the Catholic Association, in which he enrolled most of his Catholic countrymen. All over Ireland Catholic meetings were held and Catholic orators delivered angry speeches. The power of the Catholic Association was first proved by the result of the election for the county of Clare, held in July I828. Mr. Vesey Fitzgerald, a Protestant, but personally popular with his countrymen, had accepted office as President of the Board of Trade in the Duke of Wellington's Government. He was thus obliged to seek re-election. O'Connell resolved to stand against him. Even if elected, O'Connell would be unable to take his seat in Parliament; but he felt sure that the result of the poll would prove the strength of the Catholics, and that his very exclusion from Parliament would hasten the success of his cause. He was returned by an overwhelming majority. Thereupon the Duke of Wellington and his Cabinet opened their eyes to the difficulties of resistance. They perceived that the whole Catholic population of Ireland was ready to rise. To keep it down the united strength of Great Britain would have been required, but Great Britain was divided upon this question. The Duke of Wellington and Sir Robert Peel came to the conclusion that they must either prepare for civil war or yield to the Catholics. They decided to yield, but they had great difficulty in persuading others to do the same. King George IV. would not hear of concession. Most of the bishops were obstinate. With them went a majority of the lay peers. A majority of the English people, according to Peel, were on the same side, but the adhesion of the Whigs gave the Ministers an immense majority in the House of Commons. This majority and the personal influence of Wellington overpowered resistance in the House of Lords. The King was too feeble to persevere in his refusal, and the 
masses were not represented. Thus the Relief Bill was passed into law. It conferred the franchise upon the Catholics of Great Britain. It admitted the Catholics of Great Britain and Ireland to either House of Parliament. It admitted Roman Catholics to all municipal offices, to all judicial offices, except in the ecclesiastical Courts, and to all political offices, with only three exceptions, namely, the ofice of Regent, the office of Lord-Lieutenant of Ireland, and the office of Lord Chancellor in England and in Ireland. Some clauses against Jesuits and other religious orders were inserted in the Act, not so much because statesmen thought them necessary, as to calm the fears of zealous Protestants. The Act was comprehensive enough to establish real political equality between Catholics and Protestants. Unfortunately, it had been passed a generation too late and under threats of violence. It did not lessen the discontent; it only raised the demands of the Irish Catholics. It taught the dangerous lesson that the shortest way to obtain reform was to organize a league or an association for the purpose of coercing the Government of the day.

\section{Admission of Quakers, Moravians, and Separatists} to Parliament, \&c.-Members of the religious bodies known respectively as Quakers, Moravians, and Separatists had not been excluded from Parliament by any express statute; but inasmuch as every member of Parliament had to take the oath of allegiance before taking his seat, they were excluded by their conscientious objection to swearing. In I833, the first Reformed Parliament allowed Mr. Pease, a Quaker, to substitute a simple affirmation for the usual oath. An Act of that year, and an Act of I837, enabled all Nonconformists who shared in the Quaker scruple on this point to qualify by simple affirmation both for seats in Parliament and for all offices in which an oath was required. At a much later period (r888), the same indulgence was extended to every person who should declare, upon any ground whatsoever, that an oath had no binding effect upon his conscience. 
Admission of Jews to Parliament, \&c. - The religious tests devised to exclude Catholics and Nonconformists from power and place had incidentally served to exclude the Jews also. But the abolition of these tests did not admit the Jews to place and power. They were still excluded from Parliament, inasmuch as the oath of allegiance had to be sworn on the Gospels. They were still excluded from the service of the Crown and from municipal office by the words " on the true faith of a Christian," inserted in the declaration which took the place of the sacramental test. In I $830 \mathrm{Mr}$. Grant introduced the first Bill for the abolition of Jewish disabilities. It was lost on the second reading, and subsequent Bills were equally unfortunate. But in I 845 an Act was passed admitting Jews to municipal corporations. In I 847 Baron de Rothschild was elected to the House of Commons by the City of London, but was not allowed to take his seat, as he could not swear in the usual form. In 1858 the Jewish Relief Act admitted Jews to Parliament, and in 1867 the words "on the true faith of a Christian" were omitted in all cases.

Admission of Nonconformists to the Universities. One of the last steps towards the establishment of civil equality, irrespective of religious differences, was the admission of Catholics and Nonconformists to the full benefit of the English Universities. Since the year I58 I subscription to the Thirty-nine Articles had been required of all persons matriculating at Oxford. Since the year 1616 subscription had been required at Cambridge, not from persons entering the University, but from persons proceeding to degrees. At Cambridge, as well as at Oxford, scholarships and fellowships, offices and dignities, were confined to members of the Church of England. Two years after the passing of the first Reform Act, the first attempt was made to alter this state of things, but it was not until I 854 that Nonconformists were enabled to take degrees at Oxford and Cambridge. In I87 I the University Tests Act admitted them to all but a few offices in both Universities.

Abolition of Compulsory Church Rates, 1868.-At a 
time when there was only one Church in England it had become the usage to levy a rate in every parish for the maintenance and repair of the parish church. This rate was voted by the parish vestry and levied by the churchwardens. Nonconformists naturally objected to paying a rate for the parish church which they did not use, whilst they had to defray the expense of keeping up their own chapels. Discontent led to resistance. During many years Governments vainly sought for some compromise which would satisfy all parties and end the scandal. At length, in I868, Mr. Gladstone's Cabinet passed an Act abolishing compulsory church rates, but making arrangements to assist the collection of voluntary church rates.

Disestablishment and Disendowment of the Church of Ireland, 1869. - The Church of Ireland had been guaranteed by the Act of Union, but its existence was always insecure. The transfer of religious endowments from the Catholic to the Protestant Church had been effected in Ireland, not by the will of the majority of Irishmen, but by the will of the English settlers in Ireland. The majority of Irishmen had remained fervent Catholics, and the Protestant Church had made no serious or persistent effort to convert them. Even the Protestant minority were not united in defence of the Church; for a large proportion of the Protestant settlers in Ireland were of Scottish descent, and adhered to the Presbyterian doctrines of their fathers. Thus the Established Church of Ireland ministered only to the wants of a small part of the people of Ireland. As it professed to embrace the whole kingdom, and had actually received the bulk of the ancient religious endowments, the number of its ministers and the amount of its revenues were greatly in excess of the work which it had to perform. In the eighteenth century it was disfigured by many abuses. In the nineteenth century it was reformed, but it continued to rest on a narrow basis. It remained hateful to Catholics and unpopular with Presbyterians. From the time when Catholic disabilities were removed, the downfall of the Pro- 
testant Establishment in Irelanr! became certain. When the Reform Act of 1867 had placed the Liberal party in power, Mr. Gladstone adopted a policy of conciliation towards Irish Catholics. In 1869 he passed an Act to disestablish and disendow the Church of Ireland. This Act is memorable in English constitutional history as the only Act of its kind. It is also noteworthy as having reduced the number of spiritual peers by four.

Marriages and Burials of Catholics and Nonconformists. - The Common Law of England, formed at a time when all Englishmen were members of one Church, had made no provision for differences of belief respecting the rites of marriage and of burial. Nor had it provided any civil record of births, deaths, and marriages. In every parish church there was kept a register of baptisms, marriages, and burials. So long as the Church and the nation were co-extensive, this state of things caused no dissatisfaction. But when religious divisions began, it was severely felt by Catholics and Nonconformists. Like other parents, they were anxious to secure legal evidence of the birth of their children. But they could secure such evidence only by having their children baptized in the parish church. All Catholics and some Nonconformists entertained the strongest objection to such baptisms. With regard to marriage, the position of Nonconformists had been made more vexatious in recent times. Until the passing of Lord Hardwicke's Marriage Act in 1753 there had been no hindrance to their marrying elsewhere than in the parish church. The Marriage Act required that the marriages of all parties other than Jews or Quakers should be celebrated in the parish church. Thus the clergy of the Established Church were compelled, whether they liked it or no, to celebrate the marriages of persons for whom the Anglican marriage service had no sanctity. Lastly, all parish graveyards as consecrated ground were vested in the parson of the parish. No corpse could be interred there otherwise than with the forms of the Church burial service. 
The first and second of these grievances were removed by Lord John Russell in 1836. He passed an Act for the registration of births, deaths, and marriages by civil officers. Thus parents obtained legal evidence of the birth of their children without the necessity of baptism in the parish church. He passed another Act allowing persons about to be married to choose what religious ceremony they preferred, and to dispense with any religious ceremony if they thought proper. Civil registration, however, was made necessary for every marriage. When a marriage was celebrated in church, the minister was to transmit the record to the registrar.

The Nonconformist grievance respecting burials was not adjusted till many years afterwards. Where Nonconformists were numerous, they provided their own graveyards, in which they could use such rites as they approved; but in most places Nonconformists were too few to adopt this course. Nonconformists therefore demanded in England the privilege, which they already enjoyed in Ireland, of free access for their own ministers to the parish graveyard. This privilege was finally conceded by the Act to amend the Burial Laws passed in I88I. Under this Act the burial may take place at the discretion of the person in charge of the dead, either without any religious service or with such Christian and orderly religious service as he prefers.

Admission of Evidence in Courts of Justice.-According to the common law, no man's evidence could be received in a court of justice unless it were given upon oath, and the oath had been administered in the usual way. The result of this rule was to withhold the protection of the law from persons unwilling to swear in the usual form or to swear at all. Exceptions had long since been made in the case of Quakers, Moravians, and Separatists. Lord Denman's Act in 1839 enabled all persons to be sworn in the form most binding on their conscience. In I 86I every person who should declare that an oath was, according to his religious belief, unlawful, was allowed in 
criminal proceedings to make an affirmation instead of being sworn. The Act of 1888 already referred to allows an affirmation to be substituted for an oath by every witness who declares that an oath has no binding effect upon his conscience.

II. Parliamentary Reform.-The defects and irregularities in the system of parliamentary representation which have already been mentioned continued to grow more glaring down to the death of George IV. These defects and irregularities fall under two principal heads: (1) the distribution of seats, and (2) the qualifications for the franchise

(r.) The Distribution of Seats.-Since the reign of Edward I. each county and each borough had returned two members to Parliament. The exceptions to this rule were few. The Welsh counties and boroughs, when they obtained parliamentary representation, had, by reason of their small extent and population, been limited to one member apiece. The City of London, by reason of its size and importance, had long enjoyed the privilege of returning four members. Such exceptions hardly modified the effect of the rule. That rule produced great anomalies in the representation of the counties, which differ so much in size; but it produced still greater anomalies in the representation of boroughs. It produced the greatest anomaly of all in the excess of borough as compared with county members.

The faults of our borough representation had been aggravated, not amended, by the action of the Crown. Since the time of Edward I., indeed, a few insignificant boroughs had lost the right of returning members, but a far greater number of insignificant boroughs had been created. Between the accession of Henry VIII. and the death of Charles II., one hundred and eighty borough members had been added to the House of Commons. A few of the new boroughs were important places. The rest were mere villages, which had received the right of returning members in order to increase the influence of 
the Crown. Meantime the ancient boroughs had undergone all varieties of growth or of decay. Some had risen to be great cities. Others had not actually diminished, but had lost their relative importance through the development of wealth and population elsewhere. Others had actually dwindled, had lost their staple industry, or been more than half washed away by the sea. One or two could show nothing more than shapeless ruins. During the same period many villages had grown into towns. Since the beginning of the industrial revolution, populous cities had arisen upon lonely shores or in remote valleys, once tenanted only by the shepherd or the gamekeeper. Owing to all these changes, the borough representation had ceased to be anything like a genuine representation of English towns.

It should be added that the same causes which affected the distribution of seats in England had affected, to an even greater extent, the distribution of seats in Scotland and Ireland. In those kingdoms the anomalies of representation were even greater than in England.

(2.) The Qualifications for the Franchise.-The qualifications for the franchise had also been left without any general revision, and had thus become unsuitable to the condition of modern England.

The County Franchise.-In the counties every freeholder having land worth forty shillings a year was entitled to vote at parliamentary elections. Owing to the fall in the value of money, this qualification had become very low, and admitted practically every freeholder. But owing to the growth of large estates during the eighteenth century, the number of freeholders had been reduced until they were a very small part of the population of the counties. Meantime other classes of people living in the country had become important by their numbers and prosperity, but took no part in elections. There was the class of persons holding land by what is known as copyhold tenure. A copyholder is practically the owner of his land, although he owes certain services and payments 
to the lord of the manor which are not due from a freeholder. There was the class of tenant-farmers, whether holding by long leases or from year to year, who now cultivated nine-tenths of the land of England. Lastly, there were the labourers who worked for hire.

The Borough Franchise.-The qualifications for the franchise in towns were extraordinarily varied. As they had never been settled by any general statute, they depended in each town on the circumstances of its history and on the charters which it had received. In some towns every householder had a vote; in others, nobody had a vote except the members of the town council, which was often a close body, electing its own members. In other towns different intermediate systems prevailed. So far as the borough franchise had been modified, since the accession of the Tudors it had been restricted. It was much less liberal in the reign of George III. than it had been in the reign of Edward III. All these deficiencies were made more remarkable in many boroughs by the wonderful growth of their population in recent times.

Results of Anomalies in Representation.-The practical results of all the anomalies which we have described were principally twofold. The first result was to confer immense power on the owners of land, on the landed interest. This power was not due to the influence of landowners upon their tenants, for in those days no tenant, however large his holding, had a vote. It was due to the control over the borough representation exercised by the great landowners. It was said that the Duke of Rutland could return six, Lord Lonsdale nine, and the Duke of Norfolk no less than eleven members. The second result was to place a considerable part of the representation of the country under the control of the Crown-that is, of the Cabinet. So much was this the case, that when the first Reform Bill became law, many intelligent persons feared that no Ministry could keep its hold on the House of Commons or maintain a working majority. 


\section{Causes which Led to the Reform of Parliament.-}

It is difficult to say how long this strange system of representation might have lasted in quiet times. The results were not so deplorable as might have been expected. Whenever it was deeply moved, the mass of the people had generally contrived to make its wishes prevail, even in the unreformed Parliament. In ordinary times the sagacity and moderation of those who wielded such disproportionate power over Parliament had prevented their indulging in mere tyranny. But in the reign of George III. the signs of imminent change began to appear. The industrial revolution had created a vast population, which was hardly represented at all. The long war, bad harvests, and an unsound poor-law had inflicted so much suffering upon this population as to make it angry and ungovernable. The spread of democratic institutions and of democratic ideas in other countries had begun to tell upon public opinion in England. Everything was ready for a revolution in our parliamentary system.

The Reform Act of 1832. - The death of George IV. led to the election of a new Parliament in I830, and the impulse to change given by the French Revolution of that year resulted in the return of a more Liberal House of Commons. The Tory Government having been obliged to resign office, Earl Grey and the advocates of parliamentary reform came into power. They introduced a Reform Bill in the spring of $183 \mathrm{I}$. It passed the second reading in the Commons, but was abandoned in committee. Parliament was now dissolved, and the electors were favourable to the reformers. A new Reform Bill was carried through the Commons but thrown out in the Lords. Much excitement and disorder consequently prevailed in many parts of the kingdom. In the next session the third Reform Bill was carried by means of pressure which led the majority of the peers to withdraw their opposition.

Provisions of the Reform Act of 1832.-By the Reform Act of 1832 fifty-six boroughs having less than 2000 
inhabitants were totally disfranchised, and thirty boroughs having less than 4000 inhabitants lost one member. Two members were taken from Melcombe Regis and Weymouth, which had jointly returned four. The one hundred and forty-three seats thus obtained were distributed as follows:- Twenty-two new boroughs, either large towns or districts of London, received two members apiece. Twenty-one of less consequence received one member to each. Sixty-five additional members were given to the counties. The remaining seats were bestowed, eight on Scotland, and five on Ireland. In counties the franchise was extended to copyholders and leaseholders, and to tenants-at-will paying a rent of $£ 50$ or upwards. In boroughs all householders paying a rent of $£ \mathrm{IO}$ and upwards obtained the franchise, and the various local franchises were almost all abolished. Separate Reform Acts were passed for Scotland and Ireland.

Results of the Reform Act of 1832.

(I.) Diminution in the Influence of the Crown and the Landed Interest.-By extinguishing the rotten boroughs, giving representatives to the large towns, and establishing household franchise in all boroughs, the Reform Act of I 832 put an end to the parliamentary influence formerly wielded by Ministers, and reduced to an enormous extent the parliamentary power of the landed interest. It is true that the landed interest gained in some small degree by the addition made to the county representation, and by the bestowal of the franchise upon tenant-farmers, who were more or less subject to the landlord's influence. The gain, however, was no compensation for the loss. During the thirty-five years which followed the passing of the Reform Act, power lay chiefly with that middle class which had been so much augmented by the industrial revolution.

(2.) Differences of Opinion between the House of Commons and the House of Lords. - As the middle class gained the upper hand in the House of Commons, whilst the landed interest remained supreme in the House of 
Lords, the two Houses began to differ much more frequently upon questions of public policy. These differences generally ended in the House of Lords giving way. In an age of democratic revolution, the hereditary House is necessarily much weaker than the elective House. That the Lords always yielded in time to avert a dangerous conflict was largely due to the Duke of Wellington. He saw clearly that the balance of political power had shifted, and he was so highly esteemed for courage and for loyalty, that he could prevail upon his followers to accept even the most distasteful measures.

(3.) Moderate Temper of the Reformed Parliament.But the Reform Act of I832 did not result in the violent revolution which many cautious persons had feared. It did not admit any appreciable part of the labouring class to the franchise. In those boroughs where every householder had formerly enjoyed the franchise it even deprived many labouring men of their vote. The new electors whom it created were usually prosperous men, who wished indeed to see many things altered, but would by no means have consented to anarchy. The Reformed House of Commons disappointed eager reformers by its conservative temper. The greatest and most striking change which it accomplished was to establish entire freedom of trade.

Causes which Led to the Reform Act of 1867.For some years after the Reform Act of I 832, the subject of parliamentary reform was almost forgotten, but the causes which had led to that statute were still at work. The industrial revolution was still in progress; nearly the whole of our railway system has been constructed since I832. The establishment of free trade between I 840 and I 860 lessened the gains of agriculture, whilst it gave an extraordinary impulse to trade and manufactures. The rural districts almost ceased to grow in population, whilst towns became larger and larger, and wide areas were covered with mining or manufacturing villages. Thus the part of the nation which lived by the 
land was losing, and the part of the nation which lived by commerce and manufactures was gaining power.

At the same time the artisan class began to wish for political power. The elements of education were much more widely diffused; the popular standard of comfort rose considerably ; democratic ideas were making progress everywhere. On the Continent they produced in 1848 an all but universal revolution. In England they found a vent in the Chartist agitation. The object of this agitation was to obtain what were known as the five points of the People's Charter, namely, universal suffrage, vote by ballot, annual Parliaments, equal electoral districts, and payment of members. The Chartists owed much of their influence to the distress caused by hard times, and Chartism lost its vogue when prosperity returned. Still, democratic opinions continued to spread, the more rapidly, perhaps, that with the Chartists all fear of violence vanished.

The Reform Act of 1832 had broken the tradition of centuries, which made men unwilling to touch the anomalies of our representative system. A new measure of reform seemed one of the most effective ways of gaining popularity. For a generation before the passing of the Act of I832, the Whigs had rarely been in power. For a generation after the passing of that Act they had rarely been out of power. With all these inducements, the question of parliamentary reform was once more brought forward by Lord John Russell, but for some time nothing came of these discussions.

The Representation of the People Act, 1867.-This, the second Act of the kind, owed its character to the competition of Liberals and Conservatives for popular support. It was carried by $\mathrm{Mr}$. Disraeli, then a member of Lord Derby's Cabinet. It effected a small redistribution of seats, taking thirty-three from the English boroughs, and giving twenty-five to the English counties, one to the University of London, and seven to Scotland. It gave three members apiece to a few of the largest towns. 
It provided that in counties or boroughs returning three members, the elector, instead of voting for three candidates, should not vote for more than two. It effected more momentous changes in the qualification for the franchise. In counties the franchise was now extended to all occupiers rated at $£ \mathrm{I} 2$ a year. Practically the whole body of English tenant farmers acquired the franchise. In boroughs the franchise was now conferred upon all householders whatsoever, and upon lodgers paying $£$ IO a year. Thus the franchise was given to the great body of skilled artisans in the towns. The middle class of the great towns lost the larger part of that political influence which they had acquired by the first Reform Act. Separate Acts passed in I 868 introduced household franchise into Scotch and Irish boroughs.

The Representation of the People Act, 1884, and the Redistribution of Seats Act, 1885. - Causes -similar to those which had brought about the Representation of the People Act, I 867 , have brought about still vaster changes in recent years. The qualifications for the parliamentary franchise were modified by an Act of 1884 . The distribution of seats was modified by an Act of the following year.

Representation of the People Act, 1884.-This Act affected the franchise in all three kingdoms. By this Act the household franchise and lodger franchise, introduced in boroughs by the Act of I867, were extended to the counties. The franchise was thus conferred upon the whole body of agricultural labourers in England and Scotland, and of small farmers in Ireland. The other provisions of the Act were comparatively unimportant, but the extension of the household and lodger franchise to the counties was in itself a revolution.

Redistribution of Seats Act, 1885.-The provisions of this Act embrace England, Scotland, and Ireland. It has taken away the separate representation of all boroughs with less than I 5,000 inhabitants, and one member apiece from all boroughs with less than 50,000 inhabitants. It 
has taken away two members from the City of London. It has left both members to boroughs which had then between 50,000 and 165,000 inhabitants. It has taken one member from Rutland, the smallest of the English counties. The seats thus rendered available have been distributed according to a new method. The Act abandoned the principle followed in the Middle Ages, and to a considerable extent retained in modern times, of according equal representation to all the local communities, irrespective of their size. It adopted a principle, more attractive at the present day, of proportioning representation to population. It divided the United Kingdom, with the exception of the City of London and those boroughs which retained two members, into districts more or less equal in population, each of which returns one member. Thus the city of Liverpool, which had hitherto formed one constituency, and since I 867 returned three members, was divided by this Act into nine constituencies, with one member apiece. The county of Middlesex was similarly broken up into seven divisions.

But the Act, as we have seen, has not altogether ignored the old principle of distribution, and therefore the distribution which it effected is not based solely upon numbers. The Act also gave to Scotland twelve more members, thus raising the Scotch representation to seventy-two, and the total number of the House of Commons to six hundred and seventy. Scotland, Wales, and Ireland now return more members in proportion to the number of their inhabitants than does England. The representation of the Universities was not affected by the Act.

The Representation of the People Act, 1884, and the Redistribution of Seats Act, I885, have effected the most momentous change in the English Constitution ever made by statute. No one can doubt but that their consequences will be most important. The nature of these consequences, however, cannot yet be foretold.

Abatement of Bribery at Elections.-The enlargement of the constituencies, due to the Reform Acts, put 
a new difficulty in the way of corrupting the electors. Votes were now too numerous to be bought with the same ease as formerly. Political feeling ran higher, and there was a larger proportion of electors who cared enough for their party to refuse money for deserting it. Something of this improvement was due to the greater publicity given by the increasing multitude of newspapers. Still more was due to the improved method of trying petitions against successful candidates. During the greater part of the eighteenth century, election petitions were tried by a committee of the whole House of Commons, which took no pains to ascertain the facts, and gave judgment in favour of the party whose opinions agreed with those of the majority. In I770 George Grenville passed an Act which transferred the trial of election petitions to a committee of thirteen, to be chosen by the parties out of a list of forty members chosen by ballot. To this committee each party then added a nominee to maintain their respective interests. The committee thus formed showed more justice and sense of responsibility than had been shown by the committee of the whole House, but it was far from being absolutely impartial.' In 1868 , therefore, the trial of election petitions was intrusted to judges of the higher courts. The law against corrupt practices at elections was gradually rendered more stringent. The Act of I 883, the latest dealing with this subject, has rendered the old-fashioned forms of corruption difficult and dangerous. Whatever indirect means may be taken to pervert the judgment of electors, direct bribery and treating have been much reduced.

Undue Influence at Elections-The Ballot Act, 1872. -Frequent complaint had been made that so long as votes were openly recorded at parliamentary elections, many electors must be subject to undue influence. The tenant, it was said, might be intimidated by his landlord, the workman by his employer, and all who wanted to receive by all who could bestow favour or assistance of any kind. These considerations, together with the example of foreign 
democracy, led the Chartists to include secret voting, voting by ballot, among the five points of their Charter. Many able men, including Liberals as well as Conservatives, were, however, opposed to voting by ballot. They thought that if the ballot protected the voter from undue influence, it also screened him from public opinion. They thought that if the ballot was favourable to independence, it was unfavourable to the sense of responsibility. They produced no impression, however, on the popular feeling in favour of vote by ballot. It was at length established by the Ballot Act of 1872 . This Act was temporary, but has been regularly renewed ever since.

Corruption of Members of Parliament.-The corruption of members of Parliament by means of bribes, pensions, and places had virtually ceased before the close of the eighteenth century. This happy result was due partly to the personal example of high-minded statesmen like the two Pitts and Burke. It was due still more to the publicity of debates, which enabled everybody to judge how faithfully members adhered to the principles which they professed to their constituents. It was also due to the increasing interest in politics, which sharpened the vigilance of the public. Something was effected by legislation. From I 782 onwards sinecure posts had been gradually diminished in number. At the accession of William IV. all the hereditary revenues of the Crown were resigned to the nation in exchange for a moderate civil list, which was further reduced on the accession of Queen Victoria. The fund available for pensions was also curtailed. Thus any future sovereign who might wish to imitate the policy of George III. would find that he no longer possessed the means of influencing members of Parliament. The Reform Act of I832, which destroyed the rotten boroughs and made every member depend upon public favour for his continuance in Parliament, has also raised a barrier against the corrupt influence of the Crown and its Ministers.

The House of Commons and Public Opinion.-The 
Acts affecting parliamentary representation and the distribution of seats have added much to the power of the House of Commons. But other changes have augmented even more the power of public opinion over members of that House. The publication of full and accurate reports of parliamentary debates has enabled all who can read to follow the course of politics. The publication of parliamentary papers of every kind has furnished newspaper writers with abundant material for political discussion. Newspapers have been cheapened and multiplied more rapidly than ever since the abolition of the newspaper stamp (1855) and of the paper-duty (I86I). Distinguished politicians deliver almost as many set speeches to public meetings as to the House. Political questions are discussed and determined to a great extent outside the House of Commons, and the reputation of its members for special ability and special knowledge is constantly on the decline.

The Organization of Parties.-Parties exist more or less in every free country. Well-defined parties have existed in the English Parliament ever since the days of Charles I. But few attempts to organize parties outside the House were made before the middle of the last century. It is only in the present century, and since the number of persons enjoying the franchise became so large, that the organization of parties has become an art or profession demanding the industry of a lifetime. At present, every party endeavours to economise votes to the utmost. In every constituency careful inquiry is made for all the electors who are likely to support the one side or the other. Much thought is bestowed by the party chiefs in devising a policy which will gain the most general support. Constant communication is kept up between the party chiefs and the local managers. Candidates are chosen with the strictest regard to party considerations, and are usually pledged on every question of importance before they proceed to the poll. They have little subsequent freedom in determining their course. They are 
more and more becoming simple delegates charged to express the will of organized parties.

Organization for Particular Political Objects.-The organization above described is a permanent machinery for effecting all the objects of a party, but other organizations have been formed in this century, in order to compass a particular result, and have been dissolved when the work was done. Such were the Catholic Association formed to procure the abolition of Catholic disabilities; the Political Unions formed to bring about the reform of Parliament ; the Anti-Corn-Law League, of which the object was indicated by the name, and several similar combinations of more recent date. Associations of this kind have taken a memorable part in the politics of the nineteenth century, by forming public opinion, by exciting popular enthusiasm, and sometimes by threatening violent rebellion if their demands were not conceded. Such associations have not a little diminished the sense of its own independence entertained by Parliament.

III. Further Development of Cabinet Government and Changes in the Executive Departments.-The series of Reform Acts has promoted the growth of parliamentary government. Since 1832 the House of Commons has gradually acquired complete control over the general course of policy, and considerable control even over the details of Government. It has acquired absolute power to determine who shall govern. The sovereign has all but lost discretion in the choice of Ministers, and invariably calls to office the leader of the party which possesses the majority in the House of Commons. The Ministry has become entirely dependent on that majority, and resigns office as soon as its support has been withdrawn. Since 1867 Ministers have not always waited for a formal vote of want of confidence. On four occasions they have resigned simply because the result of a general election had proved unfavourable, and without waiting for the new House of Commons to assemble.

So long as the majority of the House of Commons 
upholds the Cabinet, the power of the Cabinet is more absolute now than at any former time. Its power has necessarily grown with the power of the House. The support given by the majority, in so large a body as the House of Commons, might indeed have been thought unstable. When the first Reform Act was passed, many persons feared that the extinction of the boroughs subject to the influence of the Crown would prevent any Ministry from securing a solid majority, and so shake the whole system of parliamentary government. This fear has not been realised. The old influence of the Crown has been replaced by the stringent party system above described.

The great families which formerly nominated so many members of the House of Commons were often influenced by personal feelings, which made their support of a Ministry uncertain. But their place has been taken by the professional organizers of party, whose personal feelings are not concerned in politics, and whose sole aim is to produce a large and compact majority. Formerly, also, many members sat for boroughs over which they had absolute control, so that they could not lose their seats by taking an independent part. Now, no member can feel secure in his seat unless he complies exactly with the wishes of his party. As compared with the Parliaments of the last century, the Parliaments of to-day contain a far larger proportion of men who owe all their personal importance to the fact that they are members of the House of Commons. They are, therefore, more careful not to forfeit this distinction by remissness in supporting the party cause. For all these reasons Ministerial majorities are more stable now than before the first Reform Act.

The Cabinet and Legislation.-It is particularly in the field of legislation that one may observe the absolute dependence of a modern Cabinet on the House of Commons and its absolute power whilst supported by that House. Until after the passing of the Reform Act of I832, no Ministry resigned because of failure to carry 
a legislative proposal. At the present day, failure to carry such a proposal, if important, would necessarily involve resignation or an appeal to the country. On the other hand, the Cabinet has acquired, practically, the sole power of introducing new laws. According to the letter of the Constitution, any member of either House has the right of bringing in any Bill which he thinks proper. But such has been the extraordinary increase in the number and complexity of the Bills introduced by the Government of the day, that the whole available time of the House of Commons is taken up in discussing them. A Bill introduced by a private member has hardly any chance of being discussed, much less passed, unless it is taken up by the Ministry. Upon the whole, it is well that this should be so. The bulk of our statute law is enormous. Any hasty or ill-considered addition to it is a serious evil. Some safeguard against ignorant and careless legislation is afforded by the necessity of obtaining for a Bill which is to become law the sanction of those who are intrusted with the Government.

Internal Cohesion of the Cabinet.-The same causes which have drawn closer the bond between the Cabinet and the House of Commons have strengthened the tie which unites the members of a Cabinet to one another and to their chief. Now that the sovereign has lost all real power in appointing or dismissing Ministers, it is almost impossible that there should exist in any Cabinet a party of "king's friends," seeking to thwart the chief whom they profess to support. Now that parties in the country are so vast and well disciplined, there is much less likelihood of insubordination in the Cabinet, whether prompted by family pride or by conscientious firmness. Such insubordination can usually be visited with prompt dismissal, and dismissal would mean banishment from public life. The only check upon the absolute supremacy of the Prime Minister is the inconvenience of losing the help of an able and energetic colleague. This check is no doubt effectual to some extent. The opposition of 
such a colleague in the Cabinet Council may induce a Prime Minister to modify his plans, but outward conformity with the chief is more rigorously than ever exacted from all who belong to the Ministry. The smooth working of the Cabinet system is thus ensured, at some expense of integrity. For there can be little doubt that members of a Cabinet sometimes argue with every appearance of zeal in favour of measures which in their hearts they believe useless or mischievous.

The Executive Departments.-During this period the work of the Executive has been incessantly growing. New departments have been created to perform new duties, and old departments have been remodelled in order to obtain more symmetry or greater efficiency.

The Secretaries of State.-Down to the Union of England and Scotland there had usually been two Secretaries of State. From the Union down to the suppression of the rebellion of 1745 there was a third Secretary to transact Scotch business. A third Secretary to look after Colonial Affairs was again appointed after the Seven Years' War (1756-1763) had enlarged our empire. But this Secretaryship was suppressed after the loss of most of our American possessions in 1782. A new division of duties was made between the two remaining Secretaries. One took charge of the Home Office, to which Irish and Colonial affairs were annexed. The other took charge of the Foreign Office. In the course of the great war with France, an additional Secretary was appointed to take over Colonial affairs and part of the administration of the Army. After the outbreak of the Crimean War it was found that military matters required the whole time of a Secretary, and so Colonial affairs were transferred to a fourth Secretary of State. A fifth Secretary of State for India was added in 1858 , when the government of that country passed from the East India Company to the Queen. Thus there are now five Secretaries of Statefor Home, for Foreign Affairs, for War, for the Colonies, and for India. Each is legally capable of doing the 
business of any of the others. An invariable practice makes all members of the Cabinet.

The duties of the Home Secretary are many and various. Through him pass all petitions or other communications made to the Queen in person, and all the answers given by the Queen. It is his duty to see that order is maintained throughout the kingdom, and to make arrangements for the administration of justice. He controls the prisons and the metropolitan police; he advises the Crown in the exercise of its prerogative of pardon. He is nominally responsible in these respects for Ireland as well as for England. But the real responsibility for Irish affairs rests with the Chief Secretary, who, although in form the subordinate of the Lord-Lieutenant, has in later times become an independent Minister. The Foreign Secretary supervises the relations of this country with all independent States, advises the Queen in the appointment of ambassadors and other diplomatic agents, receives and answers despatches, and obtains redress for injuries sustained by British subjects abroad. The Secretary of State for War has at the present day almost absolute control over all matters relating to the military forces of the Crown. The Secretary of State for the Colonies is intrusted with all the business arising out of the connection between the colonies and the mother country. He advises the Crown in the appointment and recall of colonial governors, in the use of the veto which it possesses on Bills which have passed a Colonial Parliament, and in all negotiations between a self-governing colony and the United Kingdom. The Secretary of State for India has a general control over the affairs of the Indian Empire; for, although the Viceroy of India in Council has powers almost equal to those of an absolute sovereign, the Viceroy is appointed and removed by the Cabinet of which the Secretary for India is a member.

The First Lord of the Admiralty.-In early times the general government of the royal navy had been vested in the Lord High Admiral, but the office of I.ord High 
Admiral was put into commission in the year 1708 , and since then has only once been revived for a short time. The duties of the office were transferred to a Board of Admiralty, but the management of naval affairs was divided between this and other Boards. It was only in I 832 that the Board of Admiralty took over the entire administration of the navy. At the present day the head of the Board, the First Lord, is really absolute, and the other members are no more than his advisers. The First Lord of the Admiralty is to the navy what the Secretary of State for War is to the army. The First Lord always has a seat in the Cabinet.

The President of the Board of Trade.-The Board of Trade was for a long time a committee of the Privy Council. Its present title dates from I862, and its present organisation from 1867 . Its duties are numerous and weighty. It collects and publishes such statistics as are thought likely to be of use in commerce and agriculture. It has charge of the standard weights and measures. It has much to do in administering the law of patents and the law of bankruptcy. It has control over railway and tramway companies, over companies which provide water, gas, or electric light, and over the whole of our merchant shipping. It also has charge of harbours and lighthouses. But here, again, the authority of the Board is merely the authority of its President. He does everything and the Board does nothing.

The President of the Local Government Board.-Experience has shown that if local authorities are to perform properly the important duties assigned to them in England, they need, as a rule, a certain amount of inspection and control by the Supreme Government. Such inspection and control hardly existed in England previous to the year I834. The Poor Law Amendment Act of that year established Commissioners to supervise the administration of poor relief, and in I 847 these Commissioners were superseded by a Poor Law Board. In I 848 a Board of Health was established in order to secure that proper 
precautions against disease should be taken by the local authorities. In 1858 this Board was suppressed, and its duties were portioned out between the Home Secretary and the Privy Council; but, with the growth of local authorities in number, in power, and in activity, it became necessary to set up a new department for their regulation. Accordingly an Act of I87 I transferred the duties of the Poor Law Board in the administration of poor relief, and the duties of the Home Secretary and Privy Council with respect to public health, to the new Local Government Board. The Local Government Board now forms one of the most important departments of State. But the Board is a mere fiction; its powers are wielded exclusively by the President, who is usually a member of the Cabinet.

The Vice-President of Council.-It was in the year I 830 that the first State grant in aid of elementary education was made. When the grant was increased in I839, a committee of the Privy Council was appointed to see that it was properly expended. An Act of 1856 appointed a Vice-President of the Committee of the Privy Council on Education. His duties have since been enormously enlarged by the Elementary Education Acts. Elementary education is now compulsory and gratuitous, and the grant in aid has risen to upwards of $£ 6,000,000$ a year. The Vice-President is becoming by degrees a Minister of Education, such as exists in most countries of the Continent. His department remains in form a committee of the Privy Council, and the President of the Council is also President of the Committee. But here, as in the case of those Boards which have grown out of similar committees, all real power is in the hands of one man, namely, the Vice-President. He is sometimes, not always, a member of the Cabinet.

Other Departments of the Executive.-Another executive department which has been constantly growing in modern times is the Post-Office. Its chief is the Postmaster-General. $\mathrm{He}$ is practically the general manager of postal business. The Board of Works was first set 
up in $\mathrm{I} 85 \mathrm{I}$. It has the care of royal palaces and parks, and of all public buildings not in the care of any of the other departments. The first Commissioner of Works really exercises all the powers of the Board. The Board of Agriculture was formed by an Act of I889. It has taken over a variety of powers from a variety of Boards and Commissions. It has to take precautions against the spread of diseases among live stock, and to publish agricultural statistics. Its powers and duties are all vested in the President.

Effect of the Increase in the Number of Departments on the Cabinet. - The increase in the number of departments has tended to enlarge the Cabinet. It is not every head of a department, indeed, who can claim to take his seat there. The five Secretaries of State and the First Lord of the Admiralty are always in the Cabinet. The nominal chief of the Treasury department, the First Lord (who is usually the Prime Minister), and its real chief, the Chancellor of the Exchequer, are also Cabinet Ministers, as a matter of course. So are the Lord Chancellor and the Lord President of the Council. The heads of departments other than those named, sometimes are and sometimes are not Cabinet Ministers. But the natural tendency is to take in as many heads of departments as possible. Cabinets are gradually becoming larger, and it is probable that in time there will be formed an inner Cabinet consisting of the Prime Minister and those colleagues whom he finds most useful.

IV. Reform of Local Administration.-Down to the death of George III. the local administration of England still bore the form impressed upon it in the time of the Tudors. It was carried on by the authorities of: (I) the Parish ; (2) the Corporate Town; and (3) the County.

The Parish.-The parish was the primary area of local self-government, both in town and in country. The parish authority was the assembly of all the rated householders, known from its place of meeting as the vestry. The incumbent of the parish acted as chairman of the 
vestry. The principal officers of the vestry were the churchwardens, the overseers of the poor, and the surveyor of highways. The principal functions of the parochial authority were the relief of the poor and the maintenance of roads. Then, as now, parishes differed extremely in extent, in population, in wealth, and in the proportion of intelligent and public-spirited householders. In most parishes the vestry was careless and its officers were incapable.

The Corporate Towns.-Almost every town of considerable antiquity had been incorporated. Each had its constitution, the outcome of special charters and of local usage. These constitutions displayed innumerable differences of detail, but too generally agreed in their narrow and exclusive spirit. As a rule, they confined municipal authority to a small number of the townspeople, or even to a council which had the right of electing its own members. The corporations were generally indolent. Many of them were also corrupt and wasted public property in private jobbery. Even when they had some public spirit they were hampered by the insufficiency of their powers. They were not in a position to carry out the extensive improvements needed when towns became large and populous. Moreover, many of the new towns which had grown out of the industrial revolution had never been incorporated, and had nothing better than the old organization of the manor, the parish, or the hundred. Owing to these circumstances a town which desired to undertake any great public work usually had to procure a special Act of Parliament creating a new authority for the purpose.

The Counties.-In each county the local administration was intrusted to the bench of magistrates. The justices, then as now, were nominated by the Crown on the recommendation of the Lord-Lieutenant from among the persons possessing a certain property qualification. Beside the judicial power which they still retain, they exercised administrative powers of the most varied description, and collectively of some importance. In many matters they 
exercised supervision over the parish authorities. The justices were, as a rule, upright and economical, although not very active in administration. Thus their possession of administrative power did not excite discontent, and was not called in question until many years after the reform of the parishes and the corporate towns.

The principal stages in the reconstruction of local government are marked by the Poor Law Amendment Act of 1834, the Municipal Corporations Act of 1835 , the series of Public Health Acts extending from I 848 to I 875 , and the County Councils Act of I 888.

The Poor Law Amendment Act, 1834.-The Ministry of Earl Grey had appointed a Commission to inquire into the abuses of the administration of the poor law. This Commission brought to light evils even greater than had been suspected. The administration of relief by the parishes was managed on such bad principles, with so much extravagance, and with so much jobbery, that it threatened to corrupt the whole wage-earning population, and to swallow up all the rental of the land. Upon the report of the Commissioners was based the Poor Law Amendment Act of I834, which transferred the administration of poor relief from single parishes to Unions. Under the provisions of this Act fifteen or twenty adjoining parishes were grouped together and elected persons to represent them on a Board of Guardians of the Poor. Thus the giving of poor relief was simplified by reducing the number of authorities entitled to give. The abuses of poor relief were lessened by intrusting it to men of higher character and better education; but the parish lost nearly all its importance as a unit of self-government.

We have already seen that the Poor Law Amendment Act introduced into local administration the principle of central control. Until the passing of that Act local authorities had generally been left to themselves, so long as they did not flagrantly transgress the law. Almost the only supervision exercised over the parish authorities was that of the county magistrates, which could not be either 
strict or uniform. The county authorities and the municipal corporations could not be said to be under any supervision whatever. If the local authority were ignorant, it was left to its ignorance; if it were idle, it could hardly be forced into activity; if it were corrupt, it needed only prudence to avoid exposure and punishment. Under these circumstances local administration was usually inefficient. The system of central control established in 1834, and now administered by the Local Government Board, has raised the standard of knowledge, industry, and integrity among local authorities. It has therefore been justified by results. At the same time it constitutes a complete departure from the immemorial English notion of self-government.

The Municipal Corporations Act, 1835.-So long as the old-fashioned municipal corporations were strongly represented in the House of Commons, they were able to defy reform. But when their political power had been destroyed by the Reform Act of 1832, their immunity from change ended. In I 835 Lord Melbourne's Government brought in a bill to do away with the old constitutions of the corporate cities and towns other than London, and to replace them by a uniform constitution of a popular nature. As finally accepted by the House of Lords, this measure provided for the election of town councillors by all the inhabitants who had paid poor-rate during the three years preceding. The town councillors were to elect a certain number of aldermen, and the councillors and aldermen together were to elect a mayor. The mayor was to hold office for one, the alderman for six, and the town councillor for three years respectively. The mayor, aldermen, and councillors together were to form the town council. Their proceedings were to be public, and their accounts were to be audited by the Treasury. Their chief functions under the Act were the lighting and watching of the borough ; but new and important duties have been conferred upon them by many later Acts, especially by the Public Health Acts. and the Acts relating to workmen's dwellings. 
A considerable number of small boroughs were exempted from the operation of this Act, and retained their quaint old constitutions for many years. An Act of 1883 abolished these boroughs, leaving the inhabitants free to petition the Crown for a charter of the modern kind. In a few of the larger towns the inhabitants have since sought and obtained such a charter. The others, which were rather villages or hamlets than towns, in any reasonable sense of the word, are now administered like the surrounding country. The Corporation of the City of London thus remains the only municipal corporation of the ancient kind.

The Corporation, however, administers but a small part of modern London. For the rest of London a peculiar administrative body was provided in $\mathrm{I} 855$. An Act of that year established the Metropolitan Board of Works to execute improvements in London outside the City. The members of the Board were chosen by the vestries of the different parishes, which in London were elective bodies chosen by the ratepayers. In I 888 the Board of Works was superseded by the London County Council, chosen by direct election, and exercising larger powers. The police of London outside the City is still kept under the control of the Government.

The corporate towns of Scotland and Ireland formerly suffered under the same abuses which prevailed in the corporate towns of England. The Scotch corporations were reformed by an Act of 1835, the Irish corporations by an Act of 1838 . In both countries the reform was carried out on principles similar to those which had been adopted in England.

The Public Health Acts, 1848-1875.-The ancient system of local government made no adequate provision for the health of the public. Such provision was first made by the Public Health Acts of the present century: Under these Acts the town councils in corporate towns and the boards of guardians in rural districts have been erected into sanitary authorities. In populous neighbour- 
hoods not forming part of any corporate town, elective local boards have been set up for sanitary purposes. All sanitary authorities are empowered to provide a water supply, to make sewers, to prevent nuisances, and to establish hospitals and cemeteries. The sanitary authorities in municipal boroughs and local board districts are further empowered to regulate traffic, to repair and cleanse thoroughfares, and to make all kinds of town improvements. The powers given by the Acts have been exercised with vigour, at all events in towns. Sanitary administration now constitutes the largest and most expensive part of the work of town councils.

The Local Government Act, 1888.-The spread of democratic ideas and the democratic remodelling of most English institutions at length led to a demand for an elective system of county government. Such a system was established by the Local Government Act of 1888 . The Act divided all England into administrative counties. These were either entire counties, or else divisions of counties already in use for administrative purposes, such as the Ridings of Yorkshire. In each administrative county was set up a council resembling that of a corporate town. The ratepayers were to elect a certain number of councillors, who were to elect aldermen, and then the aldermen and councillors were, jointly, to elect a chairman. The chairman was to hold office for one, the aldermen for six, and the councillors for three years. Councillors, aldermen, and chairman together were to form the County Council. The County Council was to take over all the administrative duties of the Justices, except two, namely, the control of the police and the granting of licenses for the sale of intoxicating liquors. But it was also to undertake some duties hitherto discharged by the inferior local authorities as well as certain petty functions hitherto reserved to the central Government. It was to elect the coroner, who had heretofore been elected by the freeholders of the county. A County Council with exceptional powers was established, as has 
already been said, to administer that part of London which lies beyond the bounds of the City.

All corporate towns of more than 50,000 inhabitants were excluded from the administrative counties, and were given the rank of county boroughs. In such boroughs the town council takes the place of a County Council.

Conclusion.-It will be seen, from this survey, that since the death of George III. the majority of English political institutions have been remodelled on democratic principles, and that the few surviving institutions which cannot be called democratic have lost much of their former power and significance. The effects of so farreaching a revolution cannot yet be determined. Great political changes are never fully understood by those who live close to the time in which they occur; but it is a reasonable ground for satisfaction when they are accomplished without violence and without breaking to pieces the traditions of an ancient and famous people. In this respect England has been singularly happy. In spite of foreign invasions, civil wars, and religious persecutions, the thread of our political life has never once been severed since the German conquest of Britain. The continuous history of English institutions has already extended over fourteen hundred years. Under these institutions the English nation has enjoyed a peace and prosperity which can scarcely be paralleled in the records of any other people. But it would be an error to suppose that good institutions are the sole, or even the principal, cause of political well-being. Institutions in themselves are dead things; they can only avail those who know how to use them, who bring to public affairs a spirit of wisdom, justice, and forbearance. These virtues have never been wholly wanting in our past. If we cherish these virtues, our future may be as glorious and still more happy. 


\section{N D EX}

Administration, central, in the Norman period, $24,26-28$; in the Tudor period, 100-102; in the present century, 218-222. See Cabinet, Curia Regis, Privy Council. local, Anglo-Saxon, 8-1 I ; Norman, 33-35; under the Tudors, 104-107; in the beginning of the present century, 222-224; reconstruction of, 224-228. See County, Hundred, Parish, Town, Township.

Admiralty, first Lord of the, 219, 220. Agreement of the People, the, I3I. Aids, feudal, 30. See Feudal Revenue. Amiens, Mise of, provisions of the, 62.

Angles, the, take part in the conquest of Britain, $\mathbf{I}$.

Assize of arms, the, provisions of, 50.

BALlot Act, the, 1872, object of, 212, 213.

Barony by writ and by tenure, distinction between, 77 .

Bate's case, I I 6 .

Benevolences, what is meant by, 82 , 96 ; first levied by Edward I., 96 ; declared illegal by Act of Richard III., 96; raised by Henry VII. and Henry VIII., 96 ; by James I., II6.

Bigod, Roger, Earl of Norfolk, refuses to serve in Gascony, 70 ; takes part in demanding the confirmation of the Charters, 7 1 .

Board of Agriculture, the, 222.

of Trade, the, President of, 220. of Works, the, 222.
Bohun, Humphrey, Earl of Hereford refuses to serve in Gascony, 70; takes part in demanding the confirmation of the Charters, $7 \mathrm{I}$.

Bolingbroke, Lord, his constitutional theory, 172, 173 .

Boniface VIII., Pope, forbids clergy to pay taxes, 6 .

Bookland, what, 3 .

Borough franchise, qualification for, in medirval period, 79 ; in later times, 107 ; previous to the Reform Act of $\mathrm{IS}_{32}, 205$; under the $\mathrm{Re}-$ form Act of 1832, 207; under the Representation of the People Act, I867, 210.

Bretwalda, what, 6 ; seven mentioned by historians, 6 .

Britain, conquest of, by German tribes, I ; effect on institutions brought from Germany, 3, 4 .

Britons, the, conquered by invaders from Germany, I ; disappearance of their political institutions, I ; doubts as to whether they were extirpated in the conquered districts, 2, note.

Buckingham, the Duke of, favourite of James I., II7; of Charles I., II8; impeachment of, II8.

Burial laws, Act to amend, 188I, purport of, 202.

Bute, Lord, the favourite of George III., 176 ; assailed by Wilkes, 179.

Cabinet, the, development of, after Revolution of 1688,163 ; the two forms of, 164 ; unpopularity of, in its earlier form, I64; growing fre- 
quency of, 165 ; later form of, under William III., I66; under Anne, 167 ; under George I., I67 ; position of Prime Minister in, 168, 169 ; deliberations of, I70; more dependent than formerly on majority in the House of Commons, 215; increase in power of, 216 ; control over legislation, 216; closer internal cohesion of, 217 ; enlargement of, 222.

Carucage, a tax on land, 46 ; a substitute for the Danegeld, 46 .

Catholic disabilities, Act for the removal of, 1829 , 196 ; events leading up to, 196, 197; purport of, 198.

Chancellor, the first, appointed by Edward the Confessor, 27 ; duties of, in the Norman period, 27; always a clergyman in Norman period, 27 ; derivation of title, 27.

Chancery, Court of, its origin, 68 ; conflicts of, with Court of King's Bench, 117.

Charles I., character of, II 8 ; his war with Spain, 118 ; with France, 118 ; disagrees with his first Parliament, II 8 ; with his second, I 8 ; calls a third Parliament, II9; grants the Petition of Right, I I9; dissolves Parliament and imprisons leaders of the Opposition, I I 9; governs eleven years without a Parliament, I20I24; his friendship for Laud, I23; persecutes Puritans, I23, I 24 ; summons the Short Parliament, I24; dissolves it, I24; calls a great council of peers at York, 124; summons the Long Parliament, I24; distrust felt for, 127, 128; tries to set his enemies at variance, I29; his part in the Civil War, 130; his trial and execution, I $\mathbf{3} \mathbf{I}$.

II., his prudence, 135 ; his religious policy, 137, 140; demands the repeal of the Triennial Act, 138 ; attempts to save Danby from impeachment, I4I ; calls no Parliament in last years of his reign, I44.
Charter, the Great, accepted by John, 53 ; its provisions as to the Church, 53 ; the tenants in chief, 54 ; cities and towns, 54; justice, 54-55; forests, 55 ; miscellaneous, 55 ; observations on, 56,57 ; republished by the Regent Pembroke, 59; violated by Henry III., 6I ; obligation of, acknowledged by Dictum de Kenilworth, 63; confirmed by Edward I., 70, 7I.

Church, the, organisation of, by Theodore, 5 ; its importance in the Anglo-Saxon period, 20 ; its relation to the State in the Norman period, 36,37 ; policy of Henry II. with reference to, $42-46$; conflict of, with John, 52 ; provision on behalf of, in Great Charter, 53; policy of Edward I. with reference to, 65; decline of its power in fourteenth and fifteenth centuries, 86-88; relation to the Crown in the Tudor period, IO7-III ; in the Stuart period, II 3 ; under James I., I1 7, I 18; under Charles I., I23, 124 ; differences respecting, in Long Parliament, 128, I29; reaction in favour of, after the Restoration, 137, 138; attacked by James II., I44-146; position of, how affected by the Toleration Act, $15^{0-1} 5^{2}$; the sovereign to be a member of, I 53, 154; reaction in favour of, under Anne, I6I, I62.

- courts separated from secular by William I., 36 ; jurisdiction of, 43,66 ; abuses of, 87 ; deprived of penal jurisdiction by Long Parliament, 126.

- of Ireland, disestablishment and disendowment of, 200, 201 .

- rates, compulsory abolition of, 199, 200.

Civil list, the, I49.

Clare, Gilbert de, Earl of Gloucester hostile to Simon de Montfort, 63 .

Richard de, Earl of Gloucester, rival of Simon de Montfort (father of Gilbert), 62. 
Clarendon, Assize of, introduces the presentment of criminals by a jury, 49.

Clarendon, Constitutions of, 44 ; their provisions, 45 ; observations on, 45 ; not carried into effect, 45 ; their historical significance, 46 .

- Earl of. See Hyde, Edward.

Clergy, the, influence of, in AngloSaxon period, 5 ; under Norman kings, $36,37,38$; under Henry II., 42 ; very numerous in Middle Ages, 44 ; under Henry III., 60 ; outlawed by Edward I., 66, 67; represented in the Model Parliament, 70 ; inferior, cease to be represented in Parliament, 76 ; cease to be leaders of the people, 86 ; diminution of zeal and increase of riches of, 87 ; strictly controlled by Henry VIII. and Elizabeth, IO7; subservient to the Crown, II2.

Coke, Lord Chief-Justice, his opinion respecting proclamations, 116 ; dismissed by James I., I 17 .

Colonies, Secretary of State for the, duties of, 219.

Common Pleas, Court of, established by the Great Charter, 55 .

Commons, House of, origin of, 53,58 , $60,62,63,69$; in the Model Parliament, 70 ; sources of its vitality, 77 , 78 ; acquires control over taxation, $81-83$; its part in legislation, 83,84 ; impeachment of members by, 85 ; increase in members of, under the Tudors, 95 ; temper of, under the Tudors, 95; power of, under the Tudors, 95-100; at variance with James I., I I5, 116 ; with Charles I., II8, I19; impeaches Laud and Strafford, 125 ; division in, 127129; purged by the army, 131; expelled by Cromwell, 131 ; power of after the Restoration, 139; after the Revolution, 148, 149, I66, I67; in relation to the Cabinet, 17 I, 172 ; influence of the Crown in, 177179 ; persecutes Wilkes, 179, 180; publication of debates of, 180-182 ; in conflict with George III., 184 ; composition of, previous to Reform Act of 1832, 205; effect of Reform Act of 1832 upon, 207, 208; relation of, to public opinion at the present day, 214 ; relation to the Cabinet, 215-217.

Confirmation of the Charters, 1297, 70,71 .

Conquest, Norman, its influence on the development of feudalism, 2224 ; on the central government, 24; on the royal power, 25; on the Witenagemote, 25 ; on the administration, 26 ; on the military system, 33 ; on the relations of Church and State, 36,37 ; on the social condition of England, 37, 38.

Constable, the, took part in administration, 26.

Conversion of the English. See Church, English.

Coroner, office of, created in 1194, $5 \mathrm{I}$; election of, transferred to the County Councils, 227.

Council, the, Vice-President of, 22 r.

- Great, the Norman form of the Witenagemote, 25 ; its composition, 25 ; its functions, 25,26 ; its consent required by the Great Charter for taxation, 54 ; its constitution as determined by the Great Charter, 54 ; found impracticable, 54.

- Privy, its origin, 68 ; the chief executive authority under the Tudors, 100 ; its composition, IOI ; its functions, 102 ; as a court of justice, 102-104, 123, 126; its decay, 139; clause in the Act of Settlement intended to revive, 154 , 155; gradually superseded by the Cabinet, 163-166; committees of, for particular departments, 165, 220, 221.

County, the, I0; origin of various, IO; constitution of, IO; officers of, II ; after the Norman Conquest, 23, 34 ; early instances of representation of, $53,60,63,69$; representation of, in the Model Parliament, 
70; in later Parliaments, 78; changes in the administration of, under the Tudors, 104, 105; administration of, in later times, 223 , 224; recent changes in administration of, 227, 228.

County franchise, qualification for, originally, 79; under Act of Henry VI., 79; under Reform Act of 1832 , 207 ; under Representation of the People Act, 1867, 210 ; under representation of the People Act, I884, 2 10.

Crewe, Lord Chief-Justice, dismissed by Charles I., I 22.

Criminous clerks, contest for jurisdiction over, 43.

Cromwell, Oliver, leader of the Independents, I 14, I30; his military achievements, 13I; expels the Rump, I3I ; virtual king of England, I3I ; his political views, I32; not allowed to become a constitutional king, I32; summons the Little Parliament, I32; becomes Lord Protector, I33; has to purge his first Parliament, I33; cannot agree with his Parliaments, I33; his death, 133 .

Thomas, 99, I0I.

Crown, influence of, in the House of Commons, I77 ; its sources, I77I79, 205 ; reduced by Reform Act of 1832,207 ; virtual extinction of, 213.

- the lands of, in Anglo-Saxon period, 3 , 12 ; grants out of, 17, 18 ; enlarged after Norman conquest, 29 ; diminished by Stephen and Matilda, 4I, 46 ; resumed by Henry II., 4I, 46.

Curia Regis (King's Court), the, established in Norman period, 28 ; composition of, 28 ; jurisdiction of, 32 ; ceased to act under Stephen, 47 ; revived by Henry II., 47 ; increase of business in, 47 ; Court of King's Bench an offshoot of, 47 ; Court of Common Pleas an offshoot of, 55 ; the Exchequer becomes a court dis- tinct from, 67; disappearance of Curia Regis, Ioo.

DANEgelt, a tax on land, 30 ; its origin, 30 ; augmented by William I., 30 ; last imposed under Henry II., 46.

Darien, isthmus of, Scotch attempt to colonise, I 59.

David, the Welsh prince, his trial, 69.

Debates, parliamentary, publication of, events leading to, I8o, I8I ; consequences of, 182 .

De donis conditionalibus, statute, I 285, purport of, 65 .

Democratic ideas, development of, in eighteenth and nineteenth centuries, I88-193, I94, 195, 206, 209 .

Disraeli, Mr., introduces the Representation of the People Act, 1867, 209.

Distraint of knighthood, what is meant by, 65 ; resorted to by Edward I., 65 ; revived by Charles I., 121 ; forbidden by Act of the Long Parliament, 126.

Domesday Book, 28 ; how compiled, 28 ; contents of, 29.

Ecclesiastical Commission, Court of, $145,147$.

Edward I., recognition of, 64 ; policy of, 64 ; with reference to the nobles, 64,65 ; to the Church, $65-67$; to the Commons, 67 ; to the administration of justice, 67,68 ; to the military system, 68 ; his tentative Parliaments, 68, 69; his Model Parliament, 69, 70; his confirmation of the Charters, 70, 71 .

III., his need of money and concessions to Parliament, 82.

IV., the first to exact benevolences, 82.

- VI. and the Reformation, 93, 108, 109.

Eliot, Sir John, instigates the impeachment of the Duke of Buckingham, I18; imprisoned in the Tower, I I9; death, I 19. 
Elizabeth, creation of new boroughs by, 95 ; her financial expedients, 96, 97 ; calls few Parliaments, 97 ; her proclamations, 98 ; her control over her ministers, 99-100; her Church government, IO7-IIO; her antipathy to the Puritans, I10; establishes the Court of High Commission, I IO, II I.

English, the conversion of, 4 ; brought into connection with civilised world by conversion, 4 ; influence of clergy upon, 5 ; united under kings of Wessex, 6 ; condition of, after Norman conquest, 37-39 ; blending of, with Normans promoted by policy of Henry II., 40; by the loss of the French provinces under John, $\mathbf{5 2}$.

Escheat, right of, what is meant by, 30. See Feudal Revenue.

Estates of the realm, what is meant by, 73, 74 .

Evidence, admission of unsworn, in courts of justice, 202, 203.

Exchequer, the origin of the name, 27 ; its functions in Norman period, 27, 28; as one of the three Common Law Courts, 67 .

Chancellor of, first appointed under Henry III., I73; increased importance of, after Treasury was put in commission, 173 ; always sits in the House of Commons, 173; always sits in the Cabinet, 222.

Exclusion Bill, the, 14I, 143.

Falkiand, Viscount, a leader of the moderate party in the Long Parliament, 127; becomes Secretary of State, 128 ; takes part with Charles in the Civil War, 129.

Ferm of the shire, what, 30 ; paid by the sheriff, 30, 3 I.

Feudal revenue, items of, 29, 30 ; regulation of, by Great Charter, 54 ; commutation of, proposed in reign of James I., II 5 ; suppressed by Long Parliament, I37 ; finally abolished by Convention Parliament, I37.
Feudalism, what is meant by, I5; when and where developed, I6; tendency to, in the Anglo-Saxon kingdom, 17 ; helped and hindered by Norman conquest, 22 ; undermined by Henry II., 4I ; by Edward I., 64 ; effect of Wars of the Roses on, 88 .

Finance, Norman, 27 ; extortions of, 28.

Folkland, what, 3 .

Folkright, what, 3 .

Forests, charter of the, published, 59 ; confirmed by Edward I., 70, 7I; enlargement of, by Charles I., I21 ; object of enlargement, I2I ; forbidden by Act of the Long Parliament, 126.

Foreign Affairs, Secretary of State for, duties of, 219.

Forfeiture, right of, what is meant by, 30. See Feudal Revenue.

Fox, Charles James, his Libel Act, I82, I83; his coalition with Lord North, I83; his India Bill, 184; driven from office, 184 .

Freemen of German tribes, 2 ; of Anglo-Saxon period, their impaired position, 19, 20; after the Norman conquest, 38 ; gradual increase in the number of, $89,90$.

French literature, its influence on English political ideas, I89.

- Revolution, its influence on English politics, I9I.

GAUNT, John of, his misgovernment, 80,85 .

George I., indifferent to English politics, 162; absents himself from Cabinet councils, 167 .

III., character of, I74 ; political aims of, 176,177 ; perseveres with the American war, 183; his conflicts with his ministers, 183,184 ; his relations with the younger Pitt, I84, I85 ; hostile to Catholic emancipation, 188 .

IV., hostile to Catholic emancipation, 197 . 
Germans, the, their institutions, 2 ; freemen and slaves among, 2; nobles, 2 ; kings, 3 ; popular assemblies of, 3 .

Ghent, Edward I. confirms the charters at, 7 I.

Gloucester, Statute of, 1278, its purport, 65 .

Gordon Riots, the, 186.

Grand assize, the, provides for determination of title to land by a jury, 49.

Grattan, Henry, obtains legislative independence of Ireland, I86; friendly to the Roman Catholics, I87.

Grenville, George, his Act relating to the trial of election petitions, 212.

ministry, the, and Catholic emancipation, 185 .

Grey, Earl, ministry of, 206.

Habeas Corpus Act, the, I679; purport of, I 42, I 43 .

Henry I., character of, 24 ; the originator of the circuits of the itinerant justices, 32 ; besieges Bridgnorth, 33; his dispute with the Church regarding investitures, 37 .

- II., character of, 40 ; issues a charter of liberties, $4 \mathrm{I}$; policy with reference to the nobles, 41,42 ; the Church, 42-46 ; the Commons, 46 ; finance, 46,47 ; justice, $47-50$; military system, 50; summary of his improvements, 50 .

- III., early years of, 59,60 ; his misgovernment, 60 ; forced to make concessions, 60 ; his dislike to reform, 62 ; accepts arbitration of Lewis IX., 62 ; defeated and taken prisoner at Lewes by Simon de Montfort, 62 ; accepts the Mise of Lewes, 62 ; recovers authority after the battle of Evesham, 63 ; death,

63. VII., his prudent administration, 92.

VIII., his breach with Rome, 93 ; his wasteful expenditure, 95 ; demands benevolences, 96 ; forced loans, 96 ; obtains Acts to relieve him of his debts, 96 ; calls no Parliament from 1523 to 1529,97 ; obtains Acts giving his proclamations the force of law, 98 ; encourages prosecution of unpopular ministers, 99 ; establishes the Council of the North and the Council of Wales, I03; Church government of, 107 ; suppresses the monasteries, 108; obtains recognition as supreme head of the Church, 108.

Household, royal officers of the, took part in administration, 26.

Hundred(Ward or Wapentake), what, 9 ; its origin, 9; first mentioned in laws of Edgar, 9 ; constitution of, 10; after the Norman conquest, 23, 34 ; practically obsolete, 104.

Hyde, Edward (Earl of Clarendon), a leader of the moderate party in the Long Parliament, 127 ; joins Charles in the Civil War, 129 ; becomes Earl of Clarendon and Lord Chancellor after the Restoration, I39; attempts to withstand the House of Commons, 139 ; impeached of high treason, 139; forced to fly the country, I39.

IMPEACHMENT, parliamentary, 85, 99, 1 16, I 17, $118,125,140,141$, I 7 , 172.

India, Secretary of State for, duties of, 2 I9.

Industrial revolution, the, what is meant by, I9I, 192; its influence favourable to democracy, 192, 193. Investitures, the dispute concerning, 37.

JAMES I., character of, I I 4, I I 5 ; his extravagance, II5; takes a benevolence in 1614 and another in 1620, I16; dismisses Lord Chief Justice Coke, II 7 ; hostile to Puritans, II 7 , I 18 .

II., accession of, 144 ; his aims, I44; attacks the Church of Eng- 
land, I44; establishes Court of Ecclesiastical Commission, I45 ; procures decision of judges in favour of the dispensing power, 145; his Declaration of Indulgence, 145; orders prosecution of Sancroft and the seven bishops, I46 ; his deposition, I46.

Jews, admission of, to Parliament, 199.

John, his misgovernment, 5I ; loses his French provinces, 52; his conflict with the Church, 52 ; with the barons, 52, 53 ; accepts the Great Charter, 53 ; released from his obligation by the Pope, 57 ; dies, 57.

Jurors in trials for treason to be freeholders, 147.

Jury, development of the, 48 ; subsequent to Norman conquest, 49 ; connected with Norman system of inquests, 49; employed to determine questions of title to land, 49 ; to present criminals before itinerant justices, 49 ; to decide on guilt or innocence of accused persons, 50.

Justice, administration of, in AngloSaxon period in local courts, 8-10; hy king, with help of Witenagemote, I4; after Norman conquest, $3 \mathrm{I}$ 33 ; under Henry II., 47-50 ; provisions of Great Charter relative to, 54, 55 ; under Edward I., 67, 68; under the Tudors, IO2-IO4; under James I., II7; under Charles I., 122, 123; under James II., 145; provisions of Bill of Rights affecting, 147 ; provision of Act of Settlement affecting, I 56.

Justices, itinerant, circuits of, first instituted by Henry I., 32 ; ceased under Stephen, 47 ; revived and improved by Henry II., 48 ; required by the Great Charter to go circuit four times a year, 55 .

- of the peace, office of, IO5; duties of, 105, 223, 224, 227.

Justiciar, the, 26 ; usually a clergyman, 26 ; duties of, in the Norman period, 26, 27; his consent required by Constitutions of Clarendon for excommunication of tenant-in-chief, 45 ; office of, held by Hubert de Burgh, 59, 60.

Jutes, the, take part in the conquest of Britain, I.

Kenilworth, Dictum de, provisions of, 63 .

King, the, how appointed among the German tribes, 3 ; not known among Angles or Saxons until the conquest of Britain, 4 ; Anglo-Saxon king, how appointed, II ; consecration of, II ; powers of, II ; revenue of, I2; limitations to power of, I2; after union of kingdoms gains additional power, I7; weakened by tendency towards feudalism, I8; power of, absolute after Norman conquest, 25 ; supreme landlord of the whole country, 29; powers of, how far lessened by the Great Charter, 57 ; by the confirmation of the Charters, 71 ; by the rise of Parliament, 85, 86; how far augmented in Tudor period, 92-94 et seq.; reduced by Long Parliament, 1 26, 127; his position after the Restoration, I 35 ; how affected by the Bill of Rights, I48; required to be a member of the Church of England, 153, I54; how affected by the progress of Cabinet government, 167, 168; his relation to the I'rime Minister, 169; endeavour of George III. to restore the power of, $175^{-179}$.

King's friends, the, 176.

Knights of the shires, why so called, 79.

LANCASTER, kings of the House of, obliged to conciliate Parliament, 72.

Langton, Stephen, Archbishop of Canterbury, produces the Charter of Henry I. at a council in St. Paul's, 53; his part in obtaining the Great Charter, 56. 
Lateran Cou:acil condemns trial by ordeal, 49.

Latimer, Lord, impeached for corruption, 85 .

Lewis, eldest son of Philip Augustus, invited over by barons in reign of John, 57 ; defeated at Lincoln, 59; agrees to withdraw from England, 59.

ioans, forced, under Henry VIII., 96 ; under Elizabeth, 96 ; under Charles I., I1 8, I 19.

Local Government Act, 1888, purport of, 227, 228.

- Government Board, the President of, 220.

London, charter given to, by Henry I., 35 ; supports the barons against John, 53 ; sends four members to Parliament, 78; supports Wilkes, I80, I8I ; representation of, increased in 1832,207 ; and in 1885 , $21 \mathrm{I}$; alterations in administration of, 226, 227.

Lords, House of, origin of, 13, 14, 25, 26, 54, 57,69; in the Model Parliament, 70 ; in later medireval period, 75,76 ; not a truly feudal assembly, 77 ; its part in taxation, 83 ; in legislation, 83,84 ; ministers impeached before, 85 ; weakness of, under the Tudors, 94 ; suppressed by the Rump, I3I ; reassembled before the Restoration, 134; Whig majority in, 16r; at variance with House of Commons, 207, 208.

Ordainers, the, 83 ; their ordinances annulled by Parliament, 83 .

Lord-Lieutenant, office of, created by Act of Philip and Mary, 105.

Marlborough, Duke of, his political position, 158 ; his relation to parties, 167.

Marriage Act, Lord Hardwicke's, 1753, effect of, 201.

right of, what. See Feudal Revenue.

Marshal, the, took part in administration, 26.
Martial law exercised under Charles I., II9 ; condemned by the Petition of Right, I I9. See Mutiny Act, Standing Army.

Military and Naval Officers' Oaths Act, 1817, purport of, 195 .

- system in Anglo-Saxon period, 20 ; in Norman period, 33 ; under Henry III., 50 ; under Edward I., 68.

- tenures in Norman period, 22, 29 ; incidents of, 29, 30 ; under Henry II., 40, 4I ; proposal to abolish in reign of James I., II 5 ; abolished by ordinance of Long Parliament, I37 ; abolition confirmed by Convention Parliament, 137.

Monarchy, the, abolished by the Rump, I3I ; restored by the Convention Parliament, 134 .

Monk, General, marches on London, I33; declares for a free Parliament, 134 .

Monopolies, creation of, by Elizabeth, 122; by James I., 122; declared unlawful by Act of Parliament in 1624,122 ; sold to companies by Charles I., I22.

Montfort, Simon de, Earl of Leicester, a leader of the barons in the reign of Henry III., 62 ; accepts arbitration of Lewis IX., 62 ; defeats Henry and takes him prisoner at Lewes, 62 ; summons representatives of cities and boroughs to Parliament, 63 ; defeated and killed at Evesham, 63 .

Moravians, admission of, to Parliament, 198.

Mortmain, statute of, 1279, purport of, 66 .

Municipal Corporations Act, I835, purport of, 225.

Mutiny Act, the, origin of, 149,150 ; effect of, 150; replaced by Army Discipline and Regulation Act, 1881, 150 .

National debt, the, I49.

Nobility of the German tribes, 2 ; os 
the Anglo-Saxon kingdom, I8; transformation of Anglo-Saxon nobility, 19; Norman nobility, 38, 39 ; policy of Henry II. with reference to, 4I, 42 ; of Edward I., 64, 65 ; position of, at end of Middle Ages, 88, 89; under the Tudors, 94, I I I.

North, Lord, his administration, I83 ; his coalition with Fox, I83; dismissed by George III., I 84 .

OCCASIONAL conformity, Bill to prevent, rejected by the House of Lords, I6I ; passed in 1710,161 ; repealed, $\mathbf{1 6 2 .}$

O'Connell, Daniel, establishes the Catholic Association, 197 ; elected member for Clare, 197.

Offices, sale of, by Norman kings, $3 \mathbf{I}$.

Osborne, Sir Thomas (Earl of Danby), impeachment of, by House of Commons, 140; constitutional questions raised in, $14 \mathrm{I}$.

Oxford, Provisions of, 6u, 6r.

PARISH, the, origin of, 8; under Tudors becomes the primary area of local administration, 105, 106 ; administration of, in early part of present century, 222, 223 ; effect of Poor Law Amendment Act, 1834, on administration of, 224 .

Parties, organization of, 2 I 4, 215.

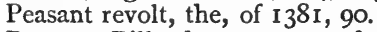

Peerage Bill, the, purport of, 163 ; rejected by the House of Commons, I63.

Pensioners, exclusion of, from House of Commons, 155 .

Petition, right of, the, subject to, 147. - of Right, the, drawn up in the third Parliament of Charles I., I I9; purport of, I I9 ; consent of Charles given to, I I9; its importance, II9; its meaning disputed, I I9.

Pipe, the great roll of the, kept by treasurer in the Norman period, 28.

Pitt, William, the younger, called to office by George III., I 84 ; his relations with George III., I84, I 85 ; introduces a Bill for the reform of Parliament, I85; effects the parliamentary union of Great Britain and Ireland, 187,188 ; involved in war with France, I9I.

Pitt, William (Lord Chatham), driven from office by George III., I75, I76; favourable to parliamentary reform, I85.

Placemen, exclusion of, from the House of Commons, 155 ; modified, I55.

Pleas, Common, Court of, its origin, 55 .

- of the Crown, proceeds of, an item of Norman revenue, $3 \mathbf{I}$.

Poor Law Amendment Act, I834, effect of, on local administration, 224.

law, the, of Elizabeth, I05, 106.

Postmaster-General, the, 22 I.

Poynings' Act, 186.

Præmunire, statutes of, purport of, 88.

President, Lord, of the Privy Council, diminished consequence of, I73: has a seat in the Cabinet, 222.

Press, the, regulated by ordinances of Council, 98, 99 ; severity of Star Chamber towards, 123; restraint of, by Long Parliament, 152 ; Licensing Act to control, passed under Charles II., I52; revived under James II., 152; expires in 1693, 152 ; freedom of, enlarged by Fox's Libel Act, 182, 183; power of, 214. Priories, the alien, suppressed, 87 .

Provisors, statutes of, purport of, 88 .

Public Health Acts, 1848-75, purport of, 226, 227.

Puritans, the, 93; their rise, IIo; disliked by Elizabeth, I IO; Parliament favourable to; I Io; Court of High Commission founded to repress, I IO, II I ; contest with James I. and Charles I., I I 3 .

Pym, John, the leader of the Puritans in the Long Parliament, 128; invited to become Chancellor of the Exchequer, 128. 
Quakers, admission of, to Parliament, 198.

Quia Emptores, Statute of, 1290, purport of, 65.

Quo Warranto, inquiry known as, 65.

Rebellion, Jacobite, of $1715,163$.

Registration of births, deaths, and marriages, Act for, 202.

Relief, what, 29. See Feudal Revenue.

Restoration, the, 1660, 134 ; its real significance, 135 .

Richard I. not a constructive statesman, $5 \mathrm{I}$.

- II. seeks to make himself absolute, 82.

Rigsdag, Swedish, the, 74 .

Sacramental test, removal of the, 196.

Saladin tithe, the, 47.

Savile, Sir George, his Bill for the relief of Roman Catholics, 186.

Saxons, the, take part in the conquest of Britain, $\mathbf{r}$.

Schism Act, its purport, 16 I ; repealed, I62.

Scutage, what is meant by, 41 ; introduced by Henry II., 4I ; effect of, 42 .

Seats, distribution of, in the Middle Ages, 78, 79; modified by creation of new boroughs under Tudors, 95 ; previous to the Reform Act of 1832 , 203, 204 ; modified by Reform Act of $1832,206,207$; by the Representation of the People Act, 1867, 209; by the Redistribution of Seats Act, 1885, 2 10, 21 I.

Secretaries of State, office of, becomes important, IOI ; changes in the number of, 218; always in the Cabinet, 219.

Secretary, Home, duties of, 219.

Self-denying Ordinance, the, I 30.

Separatists, admission of, to Parliament, 198.

Septennial Act, 1716, purport of, 163 . Shelburne, Lord, forms a ministry, 183 . Sheriff, the, in Anglo-Saxon period,
II ; powers of, augmented in Norman period, 34, 35; reduced by Henry II., 48 : forbidden to act as judge in his own county or elsewhere, $48,5 \mathrm{I}$; to be chosen by the County Court and Barons of the Exchequer, 61 ; importance of, reduced by creation of Lords-Lieutenant, I05.

Ship-money, what is meant by, 120 ; demanded in 1634, 120; in 1635, 120 ; in 1636, 121; refusal of Hampden to pay, $\mathbf{1 2 0}$; decision of the judges in Hampden's case, 121 ; ship-money demanded again in 1639, 121; declared illegal by an Act of the Long Parliament, 126.

Shire. See County.

Standing army, a, consent of Parliament requisite for keeping, I47 ; why unpopular, 149; why necessary, 150.

States-General of France, 74.

Stephen, anarchy in reign of, 38,39 ; consequent destruction of Norman nobility, $39,40$.

Strode, a leader of the Opposition in the third Parliament of Charles I., 119; imprisoned in the Tower, I19.

Suffolk, Earl of, impeached, 85.

Sunderland, Lord, his advice to William IV., $\mathbf{I} 66$.

Supplies, appropriation of, 139, 149.

Supremacy, first Act of, 1534, 108; second Act of, 1559; purport of, Iog.

TEMPLE, Sir William, his scheme for the reform of the Privy Council, 165.

Tenants-in-chief, what is meant by, I5 ; in the Great Council, 25 ; services and payments due from, 29, 30 ; military service of, commuted, $4 \mathrm{I}, 42$; provisions in favour of, in the Great Charter, 54; the lesser rarely summoned to sit in the Great Council, 57; fall into the third estate, 77 .

Test Act, 1673, purport of, 140; 
evasion of, I6I ; made nugatory by Acts of Indemnity, 162.

Test, parliamentary, Act establishing a, 1678 ; purport of, I4I.

Theodore of Tarsus, Archbishop of Canterbury, 5; organises the Church in England, 5 .

Toleration Act, 1689, how passed, 150; practical effect of, I5I ; its historical significance, I 5 I, 152.

Towns, their origin in England, 9; small, in Anglo-Saxon period, 9; primitive constitution, that of township, 9 ; growth of, in the Norman period, 35 ; progress of self-government in, 35,51 ; rights of, secured by the Great Charter, 54 ; first represented in De Montfort's Parlia ment, 63 ; represented in the Model Parliament, 70; prosperity of, at close of Middle Ages, 106 ; tendency to narrow their constitutions, 106, 107; charters of, forfeited under Charles II., I43, I44; effect of industrial revolution upon, 192, I93 ; reform of, by Municipal Corporations Act, 225.

Township, the, 8 ; an agricultural community, 8 ; a unit of administration, 8 ; an ecclesiastical division, 8; officers of, 8 ; effect of Norman conquest on, 23,34 ; in the Domesday inquest, 28 ; decay of self-government in, 104, 105.

Treasurer, the, 26 ; duties of, in Norman period, 27; his office put in commission in 1714,173 .

Treasury, First Lord of the, 173, 222. - Junior Lords of the, 173 .

Triennial Act, 1641, purport of, 126, 127 ; repealed, I38, I39; Triennial Act, 1694 , purport of, 152, 153. See Septennial Act.

'Tunnage and poundage, what, 96 , 97 ; granted to James I. for life, II 5 ; offered to Charles I. for one year, 129; levied by him without the consent of Parliament, 120; dispute whether the Petition of Right affected levying of, 120 ; Act of Long Parliament declaring consent of Parliament necessary, 126; levied by James II. before grant by Parliament; 144 .

UNIFormity, first Act of, 1559, purport of, IIO ; second Act of, I66I, purport of, 137.

Union, parliamentary, of England and Scotland, unsuccessful attempts toward, 158-160; carried out, 160 ; terms of, 160; not popular, 161; effects of, I6r.

Union, parliamentary, of Great Britain and Ireland, causes which led to, I86-I 88; carried out, I88; terms of, 188 .

United States of America, the foundation of, as affecting English political ideas, 190, 191 .

University Tests Act, the, I87I, purport of, 199.

Valentine, a leader of the Opposition in the third Parliament of Charles I., II9; imprisoned in the Tower, II9.

Villeins, condition of, after the Nor. man conquest, 38 ; provision in Great Charter for protection of, 55 ; diminution in numbers of, 89 ; services of, commuted for money payments, 90 ; disturbances among, after the Black Death, 90.

Villeinage, extinction of, 90.

WALPOLE, Robert, his resistance to the Peerage Bill, 163 ; the first Prime Minister, 172 ; antagonism to, 172 , I73.

Wapentake. See Hundred.

War, Secretary of State for, duties of, 219.

Ward. See Hundred.

Wardship, what, 30. See Feudal Revenue.

Wellington, Duke of, the, compelled to grant Catholic emancipation, 197; his influence with the House of Lords, 208. 
Wentworth, Sir Thomas (Earl of Strafford), a leader of the Opposition in the third Parliament of Charles I., I I9; goes over to Charles and is made President of the Council of the North, I I9; the chief political adviser of the king, I20; created Earl of Strafford, 120 ; impeached, 125; condemned by Act of Attainder, 125; executed, 125.

Wessex, supremacy of, 6.

Westminster, Provisions of, 6I.

Whigs, origin of name, 14I ; support the Exclusion Bill, I4I, 143; have recourse to conspiracy, 143 ; composition of Whig party, 158 ; ascendency of, under George I. and George III., I62; their divisions under George III., I75; their fall from power, 175; their mistakes after the American war, 183,184 ; their consequent exclusion from office, I84; they begin to recover strength under George IV., 196; return to power and carry the Reform Act of $1832,206$.
Whitgift, Archbishop of Canterbury, enemy to Puritans, $x$ ro.

Wilkes, John, member for Aylesbury, I 79 ; No. 45 of North Briton made the ground of a prosecution for libel against, I79; expelled the House of Commons, 179, 180 ; elected for Middlesex, 180; prevented from taking his seat, 180; encourages the publication of parliamentary debates, I8I; demands parliamentary reform, 185 .

William I., the Conqueror, his precautions against feudal anarchy, 22-24; his rapacity, 28; his Church policy, 36,37 .

Winchester, Statute of, I285, its purport, 68 .

Witenagemote, what, I3; origin of, I3 ; composition of, I3 ; powers of, I4; passes into great council of Norman kings, 25 .

Wolsey, Cardinal, 93 ; his financial demands, 95, 96; prosecution of, 99.

Wool seized by Edward I., 67 .

THE END.

Printed by Ballantyne, Hanson $\&$ Co

Edinburgh \& London 

THIS BOOK IS DUE ON THE LAST DATE STAMPED BELOW

AN INITIAL FINE OF 25 CENTS WILL BE ASSESSED FOR FAILURE TO RETURN THIS BOOK ON THE DATE DUE. THE PENALTY WILL INCREASE TO 50 CENTS ON THE FOURTH DAY AND TO \$1.00 ON THE SEVENTH DAY OVERDUE.

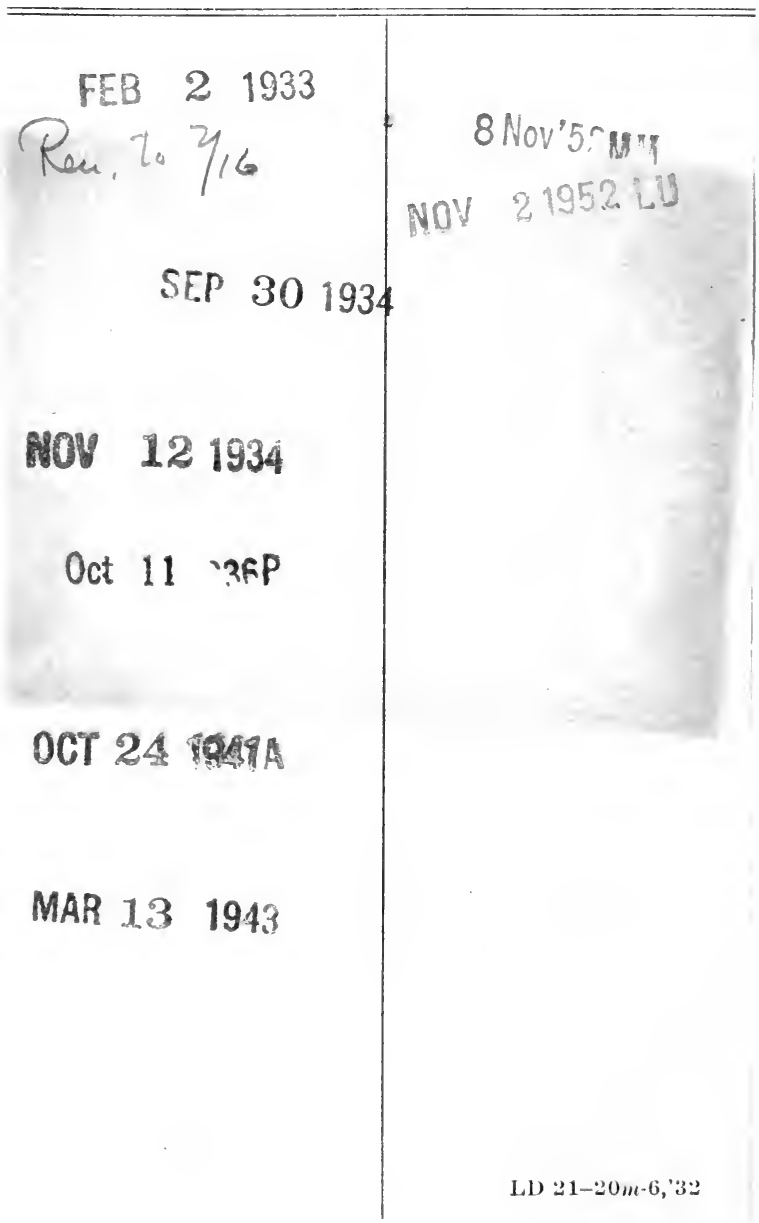




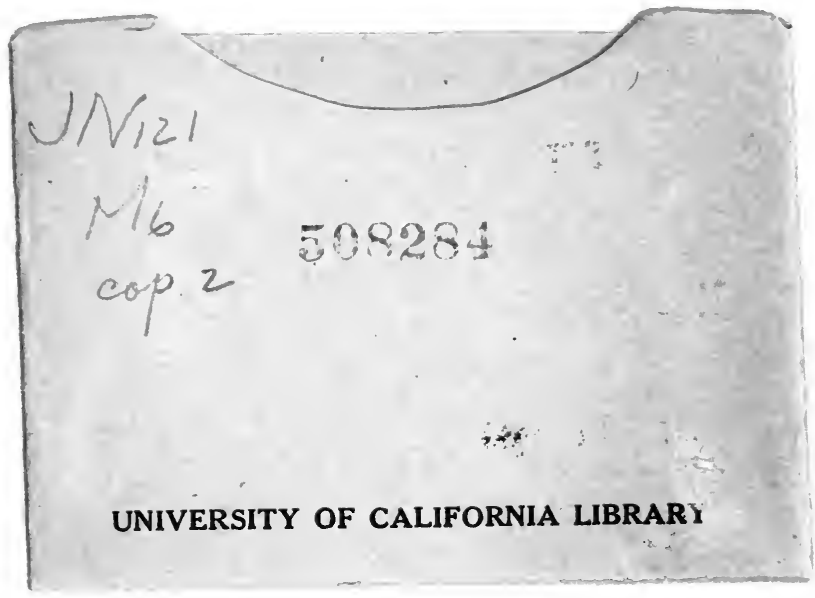


